Supporting Information for:

\title{
Water-Mediated Reversible Control of Three-State Double-Stranded Titanium(IV) Helicates
}

\author{
Naoki Ousaka, ${ }^{\dagger}, \xi$ Manabu Itakura,,$^{\dagger}$ Akira Nagasaka, ${ }^{+}$Masaki Ito, ${ }^{\dagger}$ Tomonari Hattori,${ }^{+}$ \\ Daisuke Taura, ${ }^{+,+}$Tomoyuki Ikai, ${ }^{\dagger}$ and Eiji Yashima ${ }^{*,+,+}$
}

${ }^{\dagger}$ Department of Molecular and Macromolecular Chemistry, Graduate School of Engineering, Nagoya University, Chikusa-ku, Nagoya 464-8603, Japan.

$\star$ Department of Molecular Design and Engineering, Graduate School of Engineering, Nagoya University, Chikusa-ku, Nagoya 464-8603, Japan.

$\S$ Present Address: Molecular Engineering Institute, Kyushu Institute of Technology, Tobata-ku, Kitakyushu, 804-8550, Japan.

E-mail: yashima@chembio.nagoya-u.ac.jp 


\section{Table of Contents}

1. Instruments and Materials $\quad$ S3

2. Synthetic Procedures $\quad$ S4

3. Thermal Transformation between $r a c-2 \mathbf{a}^{2-} \cdot\left(\mathrm{Na}^{+}\right)_{2}$ and $m e s o-\mathbf{2} \mathbf{b}^{2-} \cdot\left(\mathrm{Na}^{+}\right)_{2}$ Helicates $\quad \mathrm{S} 14$

4-1. Transformation between meso-2 $\mathbf{b}^{2-} \cdot\left(\mathrm{Na}^{+}\right)_{2}$ and meso-2 $\mathbf{c}^{2-} \cdot\left(\mathrm{Na}^{+}\right)_{2}$ Helicates $\quad \mathrm{S} 17$

4-2. Transformation from meso-2 $\mathbf{b}^{2-} \cdot\left(\mathrm{TBA}^{+}\right)_{2}$ to $m e s o-\mathbf{2}^{2-} \cdot\left(\mathrm{TBA}^{+}\right)_{2}$ in the Absence of Cryptand[2.2.1] $\quad$ S24

4-3. Mass Measurements of meso-2 $\mathbf{c}^{2-}$ Immediately after Preparation from meso-2 $\mathbf{b}^{2-} \quad \mathrm{S} 26$

5. Acid-Catalyzed Transformation between $r a c-2 \mathbf{a}^{2-} \cdot\left(\mathrm{Na}^{+}\right)_{2}$ and meso-2 $\mathbf{b}^{2-} \cdot\left(\mathrm{Na}^{+}\right)_{2}$ Helicates $\mathrm{S} 30$

6. X-ray Crystallographic Data $\quad$ S32

7. Theoretical Studies on the Structures of the Racemo-Titanium Helicates $\left(r a c-2 \mathbf{a}^{2-}\right.$ and $\left.r a c-2 \mathbf{d}^{2-}\right)$ and Meso-Titanium Helicates (meso-2 $\mathbf{b}^{2-}$ and meso-2 $\left.\mathbf{c}^{2-}\right) \quad$ S37

8. 2D NMR ( $g$ COSY and NOESY) Spectra of

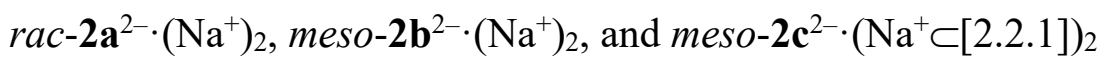

9. 2D NMR (HSQC and HMBC) Spectra of meso-2 $\left.\mathbf{b}^{2-} \cdot\left(\mathrm{Na}^{+}\right)_{2},{\mathrm{rac}-2 \mathbf{a}^{2-} \cdot(\mathrm{Na}}^{+} \subset[2.2 .1]\right)_{2}$, meso-2 $\mathbf{b}^{2-} \cdot\left(\mathrm{Na}^{+} \subset[2.2 .1]\right)_{2}$, and meso-2 $\mathbf{c}^{2-} \cdot\left(\mathrm{Na}^{+} \subset[2.2 .1]\right)_{2}$ and Their ${ }^{13} \mathrm{C}$ NMR Spectra with Peak Assignments

10. Racemization of $\mathbf{2} \mathbf{a}^{2-}$ during the Resolution of $\mathrm{rac}-\mathbf{2} \mathbf{a}^{2-} \cdot\left(\mathrm{Na}^{+}\right)_{2}$ with Optically Active Ammonium Salts

11. Transformation from meso-2 $\mathbf{b}^{2-} \cdot\left(\mathrm{Na}^{+}\right)_{2}$ to $\mathrm{rac}-\mathbf{2} \mathbf{a}^{2-} \cdot\left(\mathrm{Na}^{+}\right)_{2}$ in the Presence of Chiral Additives

12. Supporting References

13. Spectroscopic Data 


\section{Instruments and Materials.}

\section{Instruments}

The melting points were measured on a Yanaco MP-500D micromelting point apparatus (Yanako, Kyoto, Japan) and were uncorrected. The IR spectra were recorded on a JASCO FT/IR-680 spectrophotometer (JASCO, Tokyo, Japan). The NMR spectra were measured using a Bruker Ascend 500 (Bruker Biospin, Billerica, MA, USA) spectrometer, a Bruker Avance III HD 600 (Bruker, Billerica, MA, USA) spectrometer equipped with a cryoprobe or a Varian 500AS (Agilent Technologies, Santa Clara, CA, USA) spectrometer operating at $500 \mathrm{MHz}$ for ${ }^{1} \mathrm{H}$ and $125 \mathrm{MHz}$ for ${ }^{13} \mathrm{C}$ using tetramethylsilane (TMS) or a solvent residual peak as the internal standard. The absorption and CD spectra were measured in a 0.01-, 0.1-, or 1-cm quartz cell using a JASCO V-570 spectrophotometer and a JASCO J-820 spectropolarimeter, respectively. The temperature was controlled with a JASCO PTC-423L apparatus. The electrospray and cold-spray ionization (ESI and CSI) mass spectra were recorded using a JEOL JMS-T100CS mass spectrometer (JEOL, Akishima, Japan). The single crystal X-ray diffraction measurements were performed on a Rigaku Saturn 724+ CCD diffractometer with Mo K $\alpha$ radiation $(\lambda=0.71075 \AA)$ at $163 \mathrm{~K}$. The analytical and preparative chiral HPLC separations were performed on a JASCO PU-2080 liquid chromatograph equipped with UV-visible (JASCO MD-2010) and CD (JASCO CD-2095) detectors using a series of chiral HPLC columns (DAICEL, Osaka, Japan), such as CHIRALPAK IA (0.46 (i.d.) x $25 \mathrm{~cm}$ ), CHIRALPAK IB column (0.46 (i.d.) x $25 \mathrm{~cm})$, CHIRALPAK IC (0.46 (i.d.) x $25 \mathrm{~cm})$, CHIRALPAK IE (0.46 (i.d.) x $25 \mathrm{~cm})$, CHIRALPAK IG (0.46 (i.d.) x $25 \mathrm{~cm}$ ), CHIRALPAK IJ (0.46 (i.d.) x $25 \mathrm{~cm}$ ), and CHIRALPAK IA (2.0 (i.d.) x $25 \mathrm{~cm})$.

\section{Materials}

All starting materials were purchased from commercial suppliers and were used without further purification unless otherwise noted. L1 was synthesized by the procedure reported previously. ${ }^{\mathrm{S} 1}$ 


\section{Synthetic Procedures.}

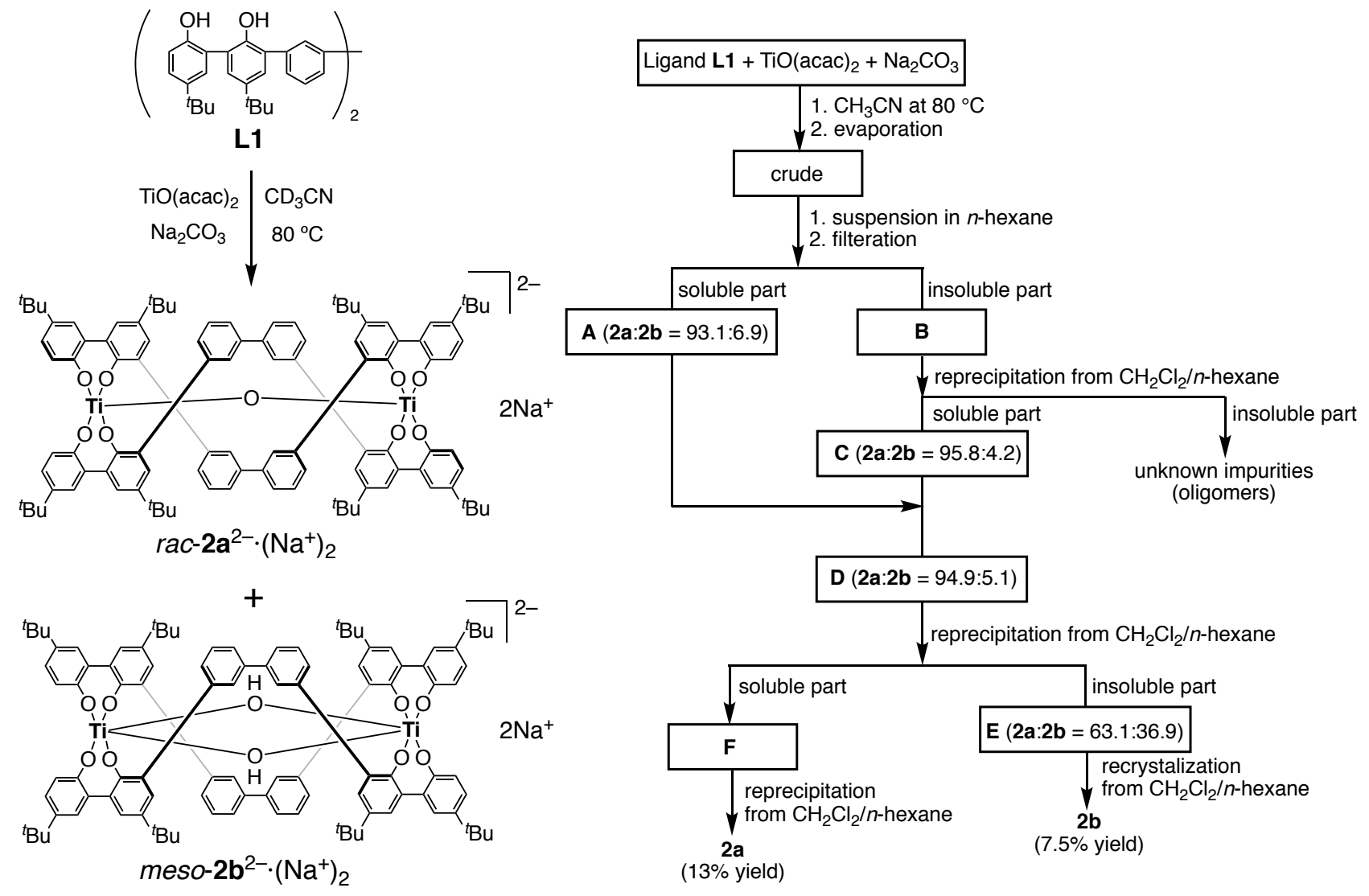

Scheme S1.

rac-2a ${ }^{2-} \cdot\left(\mathbf{N a}^{+}\right)_{2}$ and $m e s o-2 b^{2-} \cdot\left(\mathbf{N a}^{+}\right)_{2}$. To a two-neck round-bottom flask containing $\mathbf{L 1}$ (300 mg, $0.402 \mathrm{mmol}$ ), titanium(IV)oxide bis(acetylacetonate) (105 $\mathrm{mg}, 0.402 \mathrm{mmol}$ ), and sodium carbonate (42.6 mg, $0.402 \mathrm{mmol}$ ) was added $\mathrm{CH}_{3} \mathrm{CN}$ (150 mL) under nitrogen, and the suspended solution was stirred at $80^{\circ} \mathrm{C}$ for $20 \mathrm{~h}$. After the reaction mixture was cooled to room temperature, the solvent was evaporated under reduced pressure. The residue was then suspended in a large amount of $n$-hexane, and the soluble (A) and insoluble (B) parts were separated by filtration. The soluble part A composed of rac-2 $\mathbf{a}^{2-} \cdot\left(\mathrm{Na}^{+}\right)_{2}:$ meso- $-\mathbf{b}^{2-} \cdot\left(\mathrm{Na}^{+}\right)_{2}=93.1: 6.9$ was recovered by evaporation (49 $\left.\mathrm{mg}\right)$. The insoluble part $\mathbf{B}$ was further dissolved in $\mathrm{CH}_{2} \mathrm{Cl}_{2}(10 \mathrm{~mL})$ and the solution was poured into $n$-hexane $(100 \mathrm{~mL})$ to remove an $n$-hexane-insoluble part by filtration. The filtrate was evaporated to dryness under reduced pressure. The residue $(\mathbf{C})\left(108 \mathrm{mg}, \mathrm{rac}-\mathbf{2 a}^{2-} \cdot\left(\mathrm{Na}^{+}\right)_{2}: m e s o-\mathbf{2} \mathbf{b}^{2-} \cdot\left(\mathrm{Na}^{+}\right)_{2}=95.8: 4.2\right)$ combined with $\mathbf{A}$ (D) was further purified by reprecipitation from $\mathrm{CH}_{2} \mathrm{Cl}_{2}$ to $n$-hexane to afford $\mathrm{rac}-\mathbf{2} \mathbf{a}^{2-} \cdot\left(\mathrm{Na}^{+}\right)_{2}$ (43 mg, 99.7\% purity) in 13\% yield as a yellow solid. The precipitate (E) composed of rac$\mathbf{2 a}^{2-} \cdot\left(\mathrm{Na}^{+}\right)_{2}:$ meso-2 $\mathbf{b}^{2-} \cdot\left(\mathrm{Na}^{+}\right)_{2}=63.1: 36.9$ was purified by recrystallization from a $\mathrm{CH}_{2} \mathrm{Cl}_{2} / n$-hexane 
$(0.7 \mathrm{~mL} / 3.8 \mathrm{~mL})$ mixture, giving meso- $2 \mathbf{b}^{2-} \cdot\left(\mathrm{Na}^{+}\right)_{2}(25 \mathrm{mg}, 99.0 \%$ purity $)$ in $7.5 \%$ yield as a yellow solid.

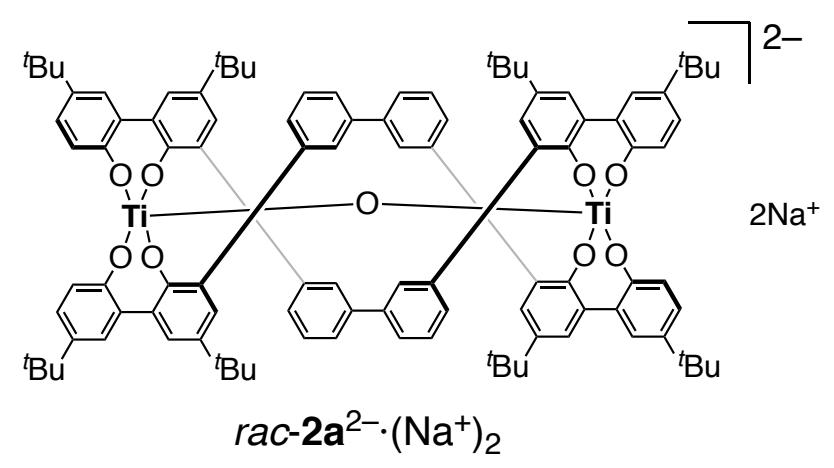

rac-2a ${ }^{2-} \cdot\left(\mathrm{Na}^{+}\right)_{2}: \mathrm{Mp}:>300{ }^{\circ} \mathrm{C} .{ }^{1} \mathrm{H}$ NMR $\left(500 \mathrm{MHz}, \mathrm{CD}_{3} \mathrm{CN}, 25^{\circ} \mathrm{C}\right): \delta 8.91(\mathrm{~s}, 4 \mathrm{H}, \mathrm{ArH}), 7.57(\mathrm{~m}$, 8H, ArH), 7.13-7.12 (m, 4H, ArH), 7.08 (d, $J=2.7$ Hz, 4H, ArH), 7.05 (d, J=2.7 Hz, 4H, ArH), 6.92 $(\mathrm{d}, J=2.6 \mathrm{~Hz}, 4 \mathrm{H}, \mathrm{ArH}), 6.51$ (dd, $J=8.5,2.6 \mathrm{~Hz}, 4 \mathrm{H}, \mathrm{ArH}), 5.00$ (d, $J=8.5 \mathrm{~Hz}, 4 \mathrm{H}, \mathrm{ArH}), 1.26$ (s, $36 \mathrm{H}, t-\mathrm{Bu}), 1.13\left(\mathrm{~s}, 36 \mathrm{H}, t\right.$-Bu); ${ }^{13} \mathrm{C} \mathrm{NMR}\left(125 \mathrm{MHz}, \mathrm{CD}_{3} \mathrm{CN}, 25{ }^{\circ} \mathrm{C}\right): \delta 162.38,160.29,143.81$, $143.10,142.01,140.80,132.01,131.71,131.30,130.07,128.81,128.26,127.86,127.78,126.62$, 126.29, 125.00, 119.86, 34.61, 34.29, 31.94, 31.83. HRMS (CSI-): $m / z$ calcd for $\mathrm{C}_{104} \mathrm{H}_{108} \mathrm{O}_{9} \mathrm{Ti}_{2}$ $\left(\mathrm{M}+\mathrm{Na}^{+}\right), 1619.6876$; found 1619.6934.

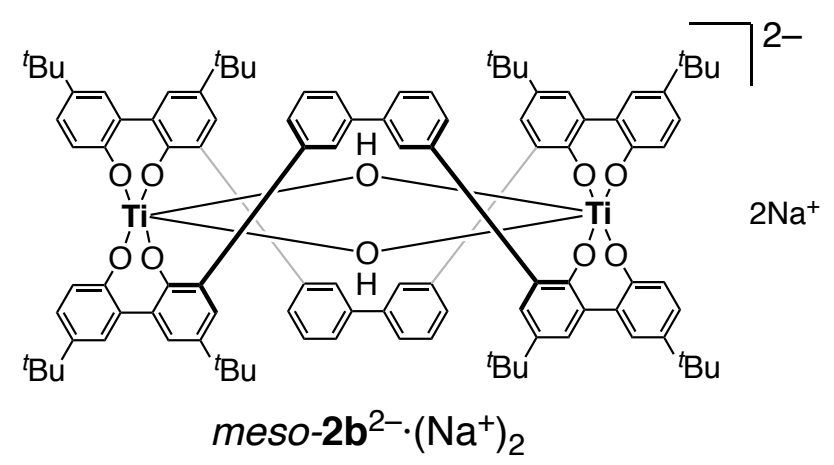

meso-2 b ${ }^{2-} \cdot\left(\mathrm{Na}^{+}\right)_{2}: \mathrm{Mp}:>300{ }^{\circ} \mathrm{C} .{ }^{1} \mathrm{H}$ NMR $\left(500 \mathrm{MHz}, \mathrm{CD}_{3} \mathrm{CN}, 25^{\circ} \mathrm{C}\right): \delta 9.43(\mathrm{~s}, 4 \mathrm{H}, \mathrm{ArH}), 8.14(\mathrm{~d}$, $J=7.6 \mathrm{~Hz}, 4 \mathrm{H}, \mathrm{ArH}), 7.48$ (t, $J=8.0 \mathrm{~Hz}, 4 \mathrm{H}, \mathrm{ArH}), 7.44-7.43$ (m, 8H, ArH), 7.09 (d, $J=2.5 \mathrm{~Hz}, 4 \mathrm{H}$, ArH), 7.00 (d, $J=2.3 \mathrm{~Hz}, 4 \mathrm{H}, \mathrm{ArH}), 6.70$ (d, $J=8.1 \mathrm{~Hz}, 4 \mathrm{H}, \operatorname{ArH}), 4.59$ (d, $J=8.4 \mathrm{~Hz}, 4 \mathrm{H}, \operatorname{ArH})$, $1.30(\mathrm{~s}, 36 \mathrm{H}, t-\mathrm{Bu}), 1.21\left(\mathrm{~s}, 36 \mathrm{H}, t\right.$-Bu). ${ }^{13} \mathrm{C} \mathrm{NMR}\left(125 \mathrm{MHz}, \mathrm{CD}_{3} \mathrm{CN}, 30{ }^{\circ} \mathrm{C}\right): \delta 163.36,160.97$, $143.58,142.56,137.08,130.67,130.00,127.98,127.76,127.57,126.71,126.21,124.26,121.87$, 117.36, 34.69, 34.52, 32.07, 31.84. $\left.{ }^{13} \mathrm{C} \mathrm{NMR} \mathrm{(125} \mathrm{MHz,} \mathrm{CD}_{2} \mathrm{Cl}_{2}, 25{ }^{\circ} \mathrm{C}\right): \delta 162.14,158.96,144.06$, $143.25,142.46,135.86,130.29$, 129.76, 129.50, 128.19, 128.07, 127.90, 127.34, 127.30, 126.23, 124.21, 121.52, 116.90, 34.45, 34.41, 31.74, 31.61. HRMS (CSI-): $m / z$ calcd for $\mathrm{C}_{104} \mathrm{H}_{110} \mathrm{O}_{10} \mathrm{Ti}_{2}$ $\left(\mathrm{M}+\mathrm{Na}^{+}\right), 1637.6982$, found 1637.6915 . 


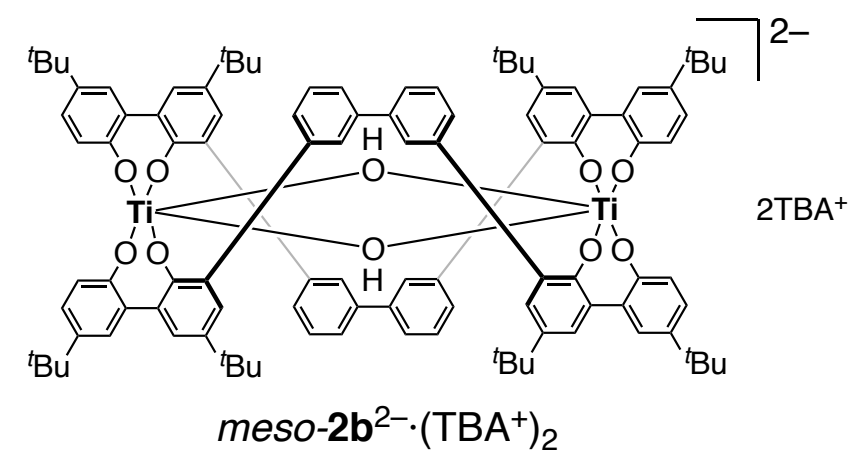

meso-2 $\mathbf{b}^{2-} \cdot\left(\mathbf{T B A}^{+}\right)_{2}$ : To a single-neck round-bottom flask containing meso-2 $\mathbf{b}^{2-} \cdot\left(\mathrm{Na}^{+}\right)_{2}(10.6 \mathrm{mg}$, $6.38 \mu \mathrm{mol})$ and cryptand[2.2.1] $(8.5 \mathrm{mg}, 26 \mu \mathrm{mol})$ was added $\mathrm{CH}_{3} \mathrm{CN}(12 \mathrm{~mL})$ and tetra- $n$ butylammonium bromide $\left(\mathrm{TBA}^{+} \mathrm{Br}^{-}\right)(206 \mathrm{mg}, 639 \mu \mathrm{mol})$ under nitrogen, and the suspended solution was stirred at room temperature for $1 \mathrm{~h}$. After evaporating the solvent, the residue was washed with water and $\mathrm{CH}_{3} \mathrm{CN}$, and then the insoluble part was dried in vacuo at room temperature overnight, giving meso-2 $\mathbf{b}^{2-} \cdot\left(\mathrm{TBA}^{+}\right)_{2}(9.3 \mathrm{mg}, 70 \%$ yield $)$.

meso-2 b ${ }^{2-} \cdot\left(\mathbf{T B A}^{+}\right)_{2}$ : Mp: $>300{ }^{\circ} \mathrm{C} .{ }^{1} \mathrm{H}$ NMR $\left(600 \mathrm{MHz}, \mathrm{CD}_{3} \mathrm{CN}, 27{ }^{\circ} \mathrm{C}\right): \delta 9.50(\mathrm{~s}, 4 \mathrm{H}, \mathrm{ArH}), 8.11$ (d, $J=7.8 \mathrm{~Hz}, 4 \mathrm{H}, \mathrm{ArH}), 7.46-7.40$ (m, 12H, ArH), 7.07 (d, $J=2.6 \mathrm{~Hz}, 4 \mathrm{H}, \mathrm{ArH}), 6.95$ (d, $J=2.5$ $\mathrm{Hz}, 4 \mathrm{H}, \mathrm{ArH}), 6.64$ (dd, J=8.4, $2.5 \mathrm{~Hz}, 4 \mathrm{H}, \mathrm{ArH}), 4.96$ (s, 2H, OH), 4.60 (d, J=8.4 Hz, 4H, ArH), 3.07-3.04 (m, 16H, $\mathrm{NCH}_{2}$ ), 1.60-1.55 (m, 16H, $\left.\mathrm{CH}_{2}\right), 1.33$ (sext, J=7.2 Hz, 16H, $\left.\mathrm{CH}_{2}\right), 1.30$ (s, 36H, $t$-Bu), $1.20\left(\mathrm{~s}, 36 \mathrm{H}, t\right.$-Bu), $0.96\left(\mathrm{t}, J=7.2 \mathrm{~Hz}, 24 \mathrm{H}, \mathrm{CH}_{3}\right) .{ }^{13} \mathrm{C} \mathrm{NMR}\left(151 \mathrm{MHz}, \mathrm{CD}_{3} \mathrm{CN}, 27{ }^{\circ} \mathrm{C}\right): \delta$ $164.20,161.91,144.12,141.19,141.06,137.23,132.21,131.43,129.44,128.44,128.12,127.68$, 127.21, 126.29, 125.62, 123.85, 121.46, 117.58, 59.26, 59.25, 59.23, 34.60, 34.37, 32.17, 31.93, 24.24, 20.29, 13.77. HRMS (CSI-): $m / z$ calcd for $\mathrm{C}_{136} \mathrm{H}_{182} \mathrm{~N}_{2} \mathrm{O}_{10} \mathrm{Ti}_{2}\left(\mathrm{M}-\mathrm{TBA}^{+}\right), 1856.9911$, found 1856.9899.



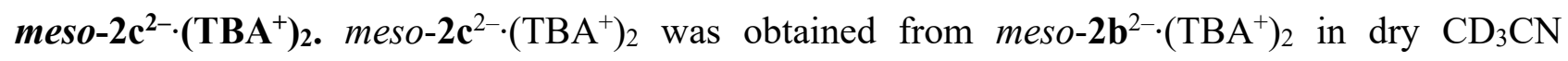
according to the following procedure. A solution of meso-2 $\mathbf{b}^{2-} \cdot\left(\mathrm{TBA}^{+}\right)_{2}(0.5 \mathrm{mg}, 0.3 \mu \mathrm{mol})$ in dry $\mathrm{CD}_{3} \mathrm{CN}(510 \mu \mathrm{L})$ was prepared in a 5-mm NMR tube under argon. To this was added $3 \mathrm{~A}$ molecular 
sieves (ca. $60 \mathrm{mg}$ ) under nitrogen to further dry the solvent. The NMR tube was then placed in an oil

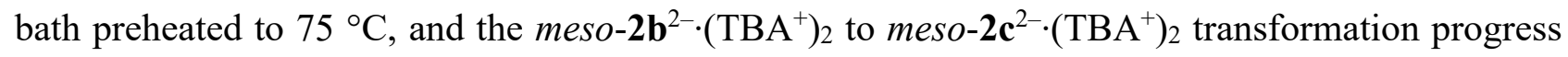
was monitored by ${ }^{1} \mathrm{H}$ NMR spectroscopy at an appropriate time interval (Figure S13).

meso-2 $\mathbf{c}^{2-} \cdot\left(\mathrm{TBA}^{+}\right)_{2}:{ }^{1} \mathrm{H}$ NMR $\left(600 \mathrm{MHz}, \mathrm{CD}_{3} \mathrm{CN}, 27^{\circ} \mathrm{C}\right):{ }^{1} \mathrm{H} \mathrm{NMR}\left(600 \mathrm{MHz}, \mathrm{CD}_{3} \mathrm{CN}, 27{ }^{\circ} \mathrm{C}\right): \delta$ 9.51 (s, 4H, ArH), 8.07 (d, J=7.2 Hz, 4H, ArH), 7.45-7.40 (m, 12H, ArH), 7.08 (d, J=2.5 Hz, 4H, ArH), 6.91 (d, $J=2.6 \mathrm{~Hz}, 4 \mathrm{H}, \mathrm{ArH}), 6.69$ (dd, $J=8.4,2.5 \mathrm{~Hz}, 4 \mathrm{H}, \mathrm{ArH}), 5.08$ (d, $J=8.4 \mathrm{~Hz}, 4 \mathrm{H}$, ArH), 3.08-3.05 (m, 16H, $\mathrm{NCH}_{2}$ ), 1.61-1.56 (m, 16H, $\mathrm{CH}_{2}$ ), 1.34 (sext, $J=7.2 \mathrm{~Hz}, 16 \mathrm{H}, \mathrm{CH}_{2}$ ), 1.30 $(\mathrm{s}, 36 \mathrm{H}, t-\mathrm{Bu}), 1.20(\mathrm{~s}, 36 \mathrm{H}, t-\mathrm{Bu}), 0.96\left(\mathrm{t}, J=7.2 \mathrm{~Hz}, 24 \mathrm{H}, \mathrm{CH}_{3}\right) .{ }^{13} \mathrm{C} \mathrm{NMR}\left(151 \mathrm{MHz}, \mathrm{CD}_{3} \mathrm{CN}\right.$, $\left.27^{\circ} \mathrm{C}\right): \delta 163.38,161.14,143.33,141.58,141.19,137.98,130.97,130.23,129.12,128.34,128.32$, 127.97, 127.16, 126.03, 125.82, 123.91, 122.08, 119.54, 59.28, 59.26, 59.24, 34.64, 34.40, 32.11, 31.94, 24.25, 20.30, 20.28, 13.77. HRMS (CSI-): $m / z$ calcd for $\mathrm{C}_{136} \mathrm{H}_{180} \mathrm{~N}_{2} \mathrm{O}_{9} \mathrm{Ti}_{2}\left(\mathrm{M}-\mathrm{TBA}^{+}\right.$), 1838.9805, found 1838.9782 .

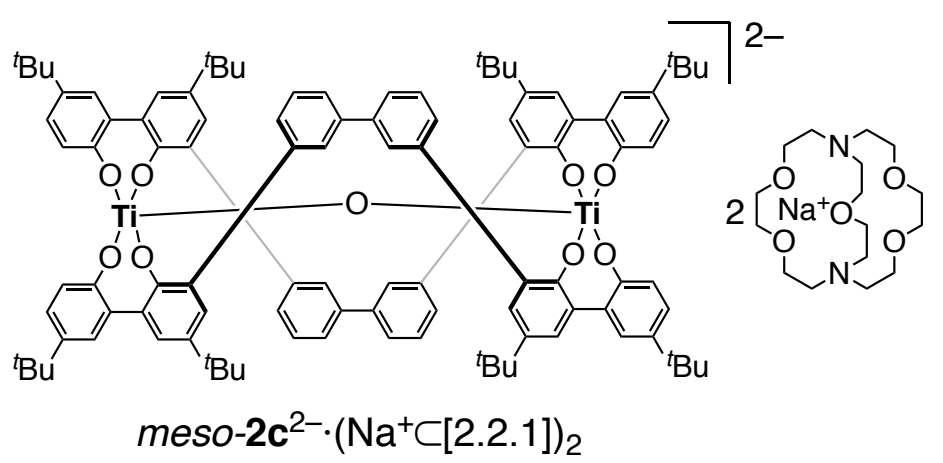

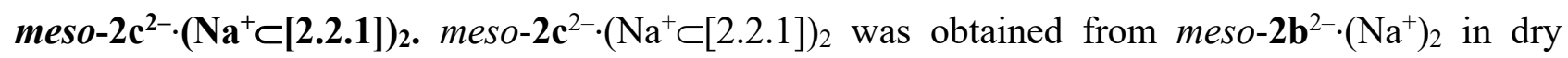
$\mathrm{CD}_{3} \mathrm{CN}$ according to the following procedure. A solution of meso- $\mathbf{2} \mathbf{b}^{2-} \cdot\left(\mathrm{Na}^{+}\right)_{2}(0.60 \mathrm{mg}, 0.36 \mu \mathrm{mol})$ in dry $\mathrm{CD}_{3} \mathrm{CN}(700 \mu \mathrm{L})$ was prepared in a 5-mm NMR tube under argon. To this was added a solution of cryptand[2.2.1] $(79.1 \mathrm{mM}, 19 \mu \mathrm{L}, 1.5 \mu \mathrm{mol})$ in dry $\mathrm{CD}_{3} \mathrm{CN}$. The NMR tube was then placed in an

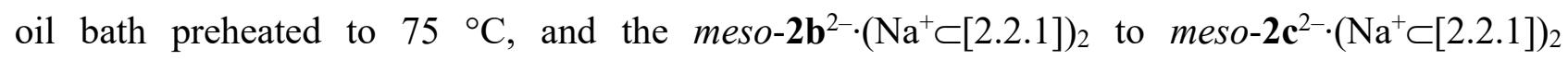
transformation progress was monitored by ${ }^{1} \mathrm{H}$ NMR spectroscopy at an appropriate time interval (Figure S9).

meso-2 $\mathbf{c}^{2-} \cdot\left(\mathrm{Na}^{+} \subset[2.2 .1]\right) 2:{ }^{1} \mathrm{H}$ NMR $\left(500 \mathrm{MHz}, \mathrm{CD}_{3} \mathrm{CN}, 25^{\circ} \mathrm{C}\right): \delta 9.52(\mathrm{~s}, 4 \mathrm{H}, \mathrm{ArH}), 8.07(\mathrm{~d}, J=7.0$ $\mathrm{Hz}, 4 \mathrm{H}, \mathrm{ArH}), 7.45-7.40$ (m, 12H, ArH), 7.08 (d, J=2.5 Hz, 4H, ArH), 6.91 (d, J=2.5 Hz, 4H, ArH), $6.68(\mathrm{dd}, J=8.4,2.5 \mathrm{~Hz}, 4 \mathrm{H}, \mathrm{ArH}), 5.09$ (d, $J=8.5 \mathrm{~Hz}, 4 \mathrm{H}, \mathrm{ArH}), 1.30$ (s, 36H, $t$-Bu), 1.20 (s, 36H, $t$-Bu). ${ }^{13} \mathrm{C}$ NMR $\left(150 \mathrm{MHz}, \mathrm{CD}_{3} \mathrm{CN}, 27{ }^{\circ} \mathrm{C}\right): \delta 163.45,160.23,143.39,141.45,141.07,138.00$, 
$131.02,130.28,129.09,128.32,127.92,127.14,126.02,125.78,123.87,122.05,119.60,34.63,34.38$, $32.12,31.95$.
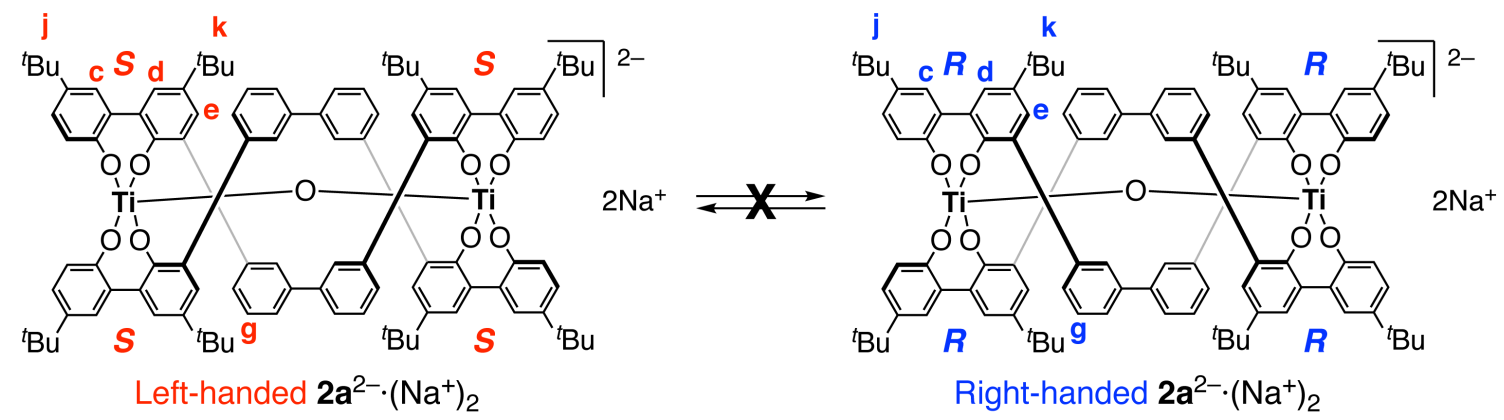

(a)
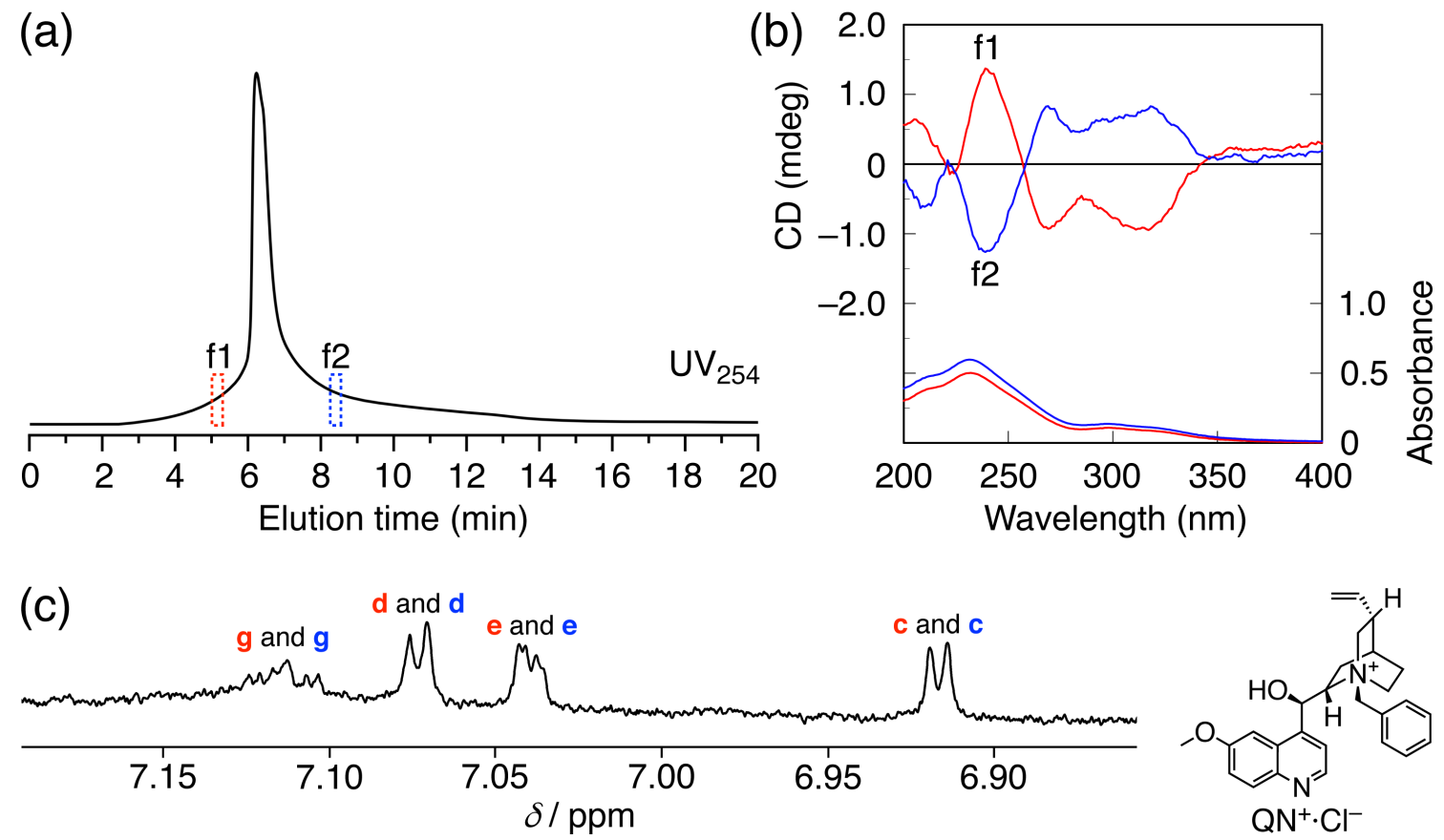

Figure S1. (a) UV detected HPLC chromatogram of $r a c-2 a^{2-} \cdot\left(\mathrm{Na}^{+}\right)_{2}\left(2.0 \mathrm{mg} \mathrm{mL}{ }^{-1}\right)$. HPLC conditions: column, CHIRALPAK IA (DAICEL, 2.0 (i.d.) $\times 25 \mathrm{~cm}$ ); eluent, $\mathrm{CH}_{3} \mathrm{CN}$; flow rate, 8.0 $\mathrm{mL} \mathrm{min}{ }^{-1}$; column temperature, $25^{\circ} \mathrm{C}$. (b) $\mathrm{CD}$ and absorption spectra of optically active $2 \mathbf{a}^{2-} \cdot\left(\mathrm{Na}^{+}\right)_{2}$ (f1 and $\mathrm{f} 2$ ) in $\mathrm{CH}_{3} \mathrm{CN}$ at $25^{\circ} \mathrm{C}$. (c) Partial ${ }^{1} \mathrm{H}$ NMR spectrum of optically active $\mathbf{2 \mathbf { a } ^ { 2 - }} \cdot\left(\mathrm{Na}^{+}\right)_{2}$ (f2) (500 $\mathrm{MHz}, \mathrm{CD}_{3} \mathrm{CN}$ containing $\mathrm{H}_{2} \mathrm{O}\left(\left[\mathrm{H}_{2} \mathrm{O}\right]_{0} /\left[2 \mathrm{a}^{2-} \cdot\left(\mathrm{Na}^{+}\right)_{2}\right]_{0}=\right.$ ca. 20$\left.), 0.05 \mathrm{mM}, 25^{\circ} \mathrm{C}\right)$ in the presence of 50 equiv of $N$-benzylquininium chloride $\left(\mathrm{QN}^{+} \cdot \mathrm{Cl}^{-}\right)$. A set of two coaxial NMR tubes (diameters: inner tube, $1.7 \mathrm{~mm}$; outer tube, $5.0 \mathrm{~mm}$ ) (Shigemi, Tokyo, Japan) was used, in which a solution of the optically active $2 \mathbf{a}^{2-} \cdot\left(\mathrm{Na}^{+}\right)_{2}$ (f2) with 50 equiv of $\mathrm{QN}^{+} \cdot \mathrm{Cl}^{-}$was transferred into a $1.7 \mathrm{~mm}$ inner tube and $\mathrm{CD}_{3} \mathrm{CN}$ was placed in a thin layer between the inner and the outer tube.

The double-helical $2 \mathbf{a}^{2-\cdot}\left(\mathrm{Na}^{+}\right)_{2}$ displayed nonequivalent proton signals $\left(\mathrm{H}_{\mathrm{e}}\right)$ resulting from the formation of a pair of diastereomers composed of right- and left-handed double-helices of $\mathbf{2 a}^{2-}$ complexed with $\mathrm{QN}^{+}$(see Figure S50d). Based on the relative peak intensities of the $\mathrm{H}_{\mathrm{e}}$ signals (Figure S1c), the enantiomeric excess of the optically active $2 \mathbf{a}^{2-}$ was roughly estimated be less than $10 \%$ ee. 

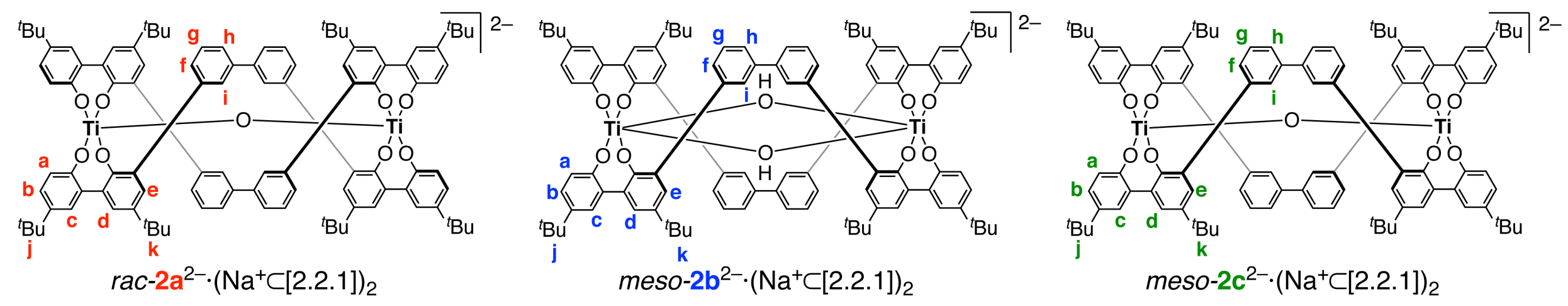

(a) rac-2a ${ }^{2-} \cdot\left(\mathrm{Na}^{+} \subset[2.2 .1]\right)_{2}$

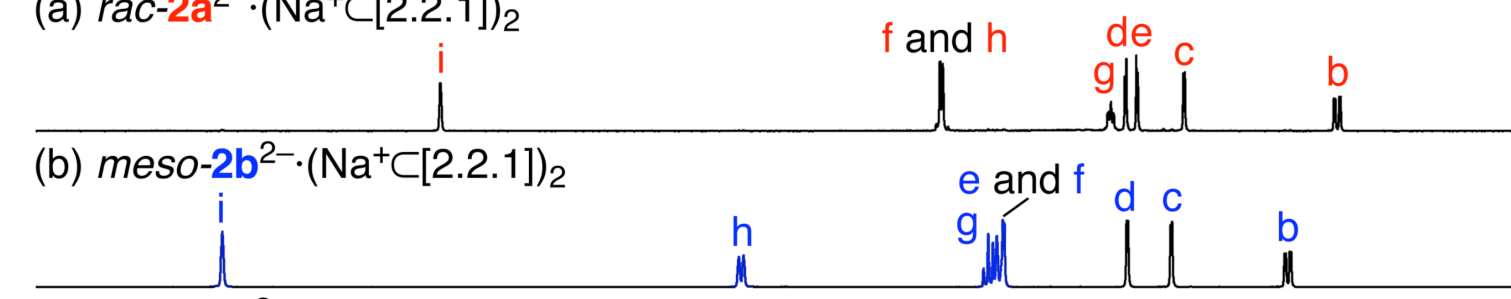

(c) $m e s o-2 c^{2-} \cdot\left(\mathrm{Na}^{+} \subset[2.2 .1]\right)_{2}$
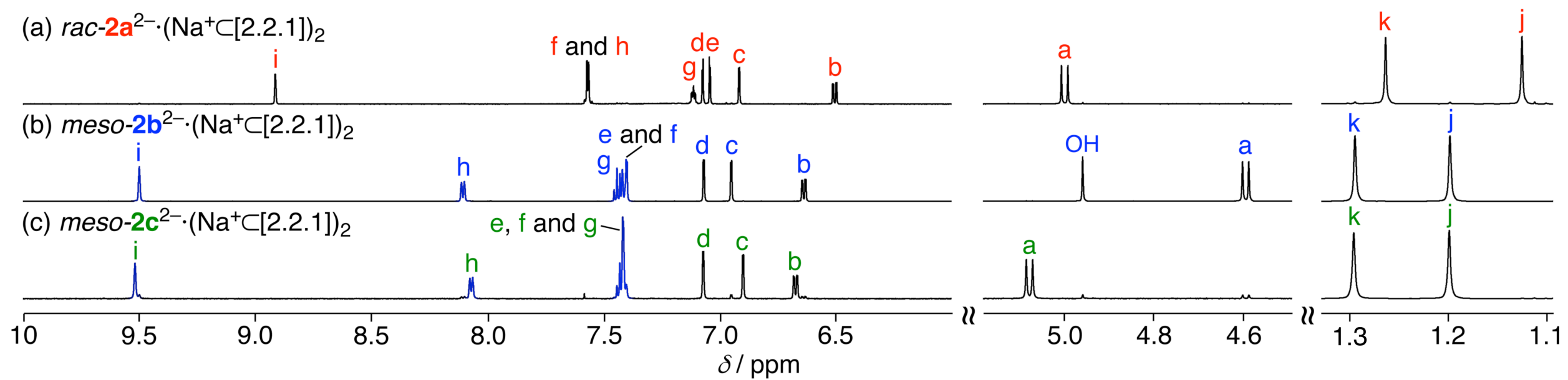

Figure S2. ${ }^{1} \mathrm{H}$ NMR spectra of $r a c-2 a^{2-} \cdot\left(\mathrm{Na}^{+} \subset[2.2 .1]\right)_{2}(0.50 \mathrm{mM})(\mathrm{a}), \operatorname{meso}-\mathbf{2} \mathbf{b}^{2-} \cdot\left(\mathrm{Na}^{+} \subset[2.2 .1]\right)_{2}(2.0 \mathrm{mM})(\mathrm{b})$, and $m e s o-2 \mathbf{c}^{2-} \cdot\left(\mathrm{Na}^{+} \subset[2.2 .1]\right)_{2}(0.50$ $\mathrm{mM})(\mathrm{c})\left(600 \mathrm{MHz}, \mathrm{CD}_{3} \mathrm{CN}, 4\right.$ equiv of cryptand[2.2.1], rt). The peak assignments were done on the basis of $g \mathrm{COSY}$ and NOESY spectra of rac$2 \mathbf{a}^{2-} \cdot\left(\mathrm{Na}^{+}\right)_{2}(2.5 \mathrm{mM})$, meso-2 $\mathbf{b}^{2-} \cdot\left(\mathrm{Na}^{+}\right)_{2}(2.5 \mathrm{mM})$, and meso-2 $\mathbf{c}^{2-} \cdot\left(\mathrm{Na}^{+} \subset[2.2 .1]\right)_{2}(0.50 \mathrm{mM})$ (Figures S23-S40). 

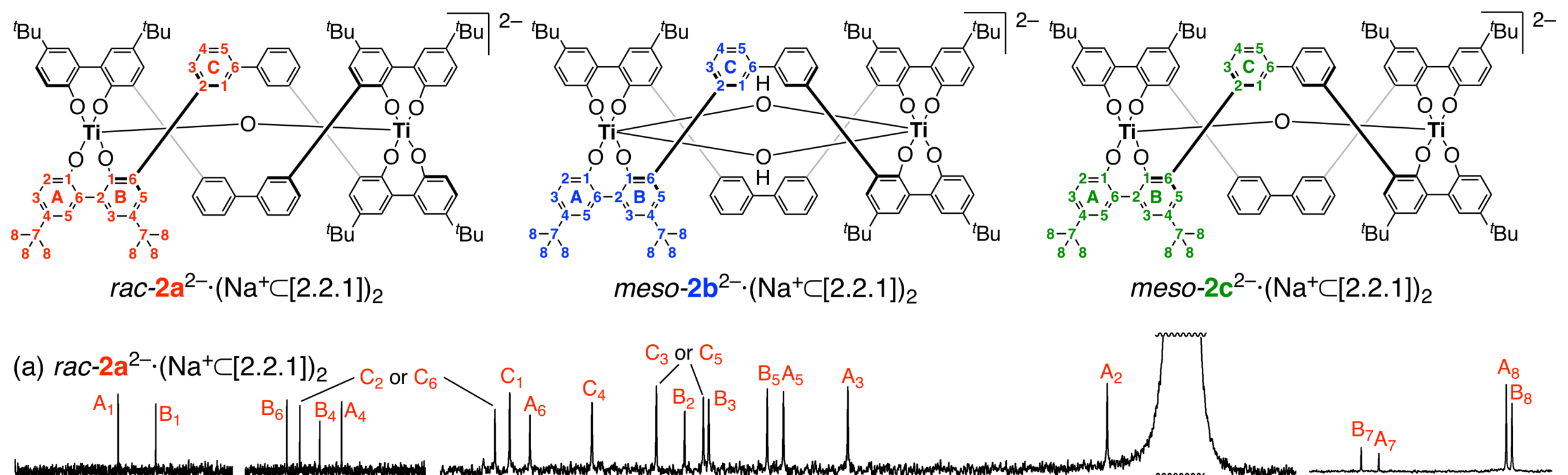

(b) $m e s o-2 b^{2-} \cdot\left(\mathrm{Na}^{+} \subset[2.2 .1]\right)_{2}$

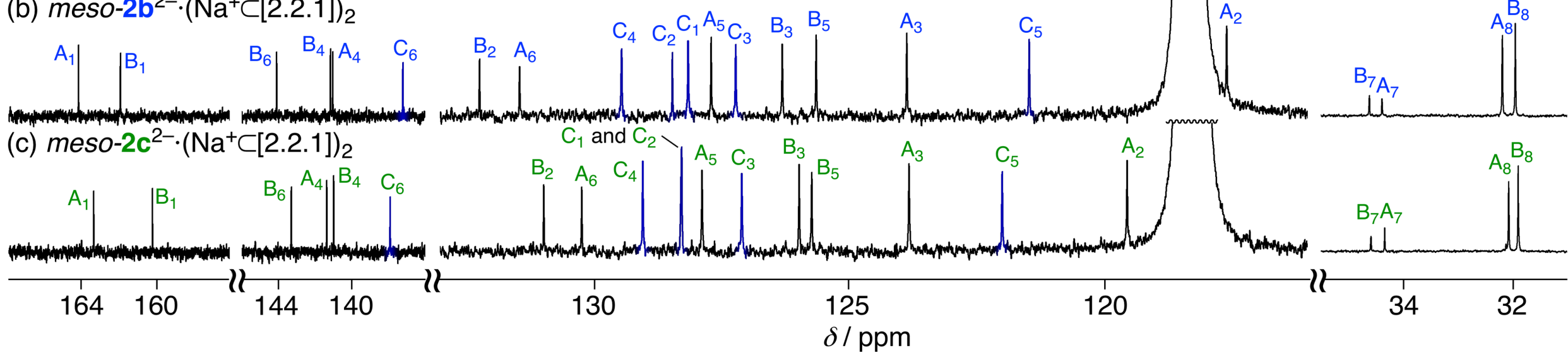

Figure S3. Partial ${ }^{13} \mathrm{C}$ NMR spectra of $r a c-2 a^{2-} \cdot\left(\mathrm{Na}^{+} \subset[2.2 .1]\right)_{2}(0.50 \mathrm{mM})(\mathrm{a})$, meso-2 $\mathbf{b}^{2-} \cdot\left(\mathrm{Na}^{+} \subset[2.2 .1]\right)_{2}(2.0 \mathrm{mM})(\mathrm{b})$, and $m e s o-2 \mathbf{c}^{2-} \cdot\left(\mathrm{Na}^{+} \subset[2.2 .1]\right)_{2}$ $(0.50 \mathrm{mM})(\mathrm{c})\left(600 \mathrm{MHz}, \mathrm{CD}_{3} \mathrm{CN}, 4\right.$ equiv of cryptand[2.2.1], rt). The peak assignments were done on the basis of HSQC and HMBC spectra (Figures S43-S48). 

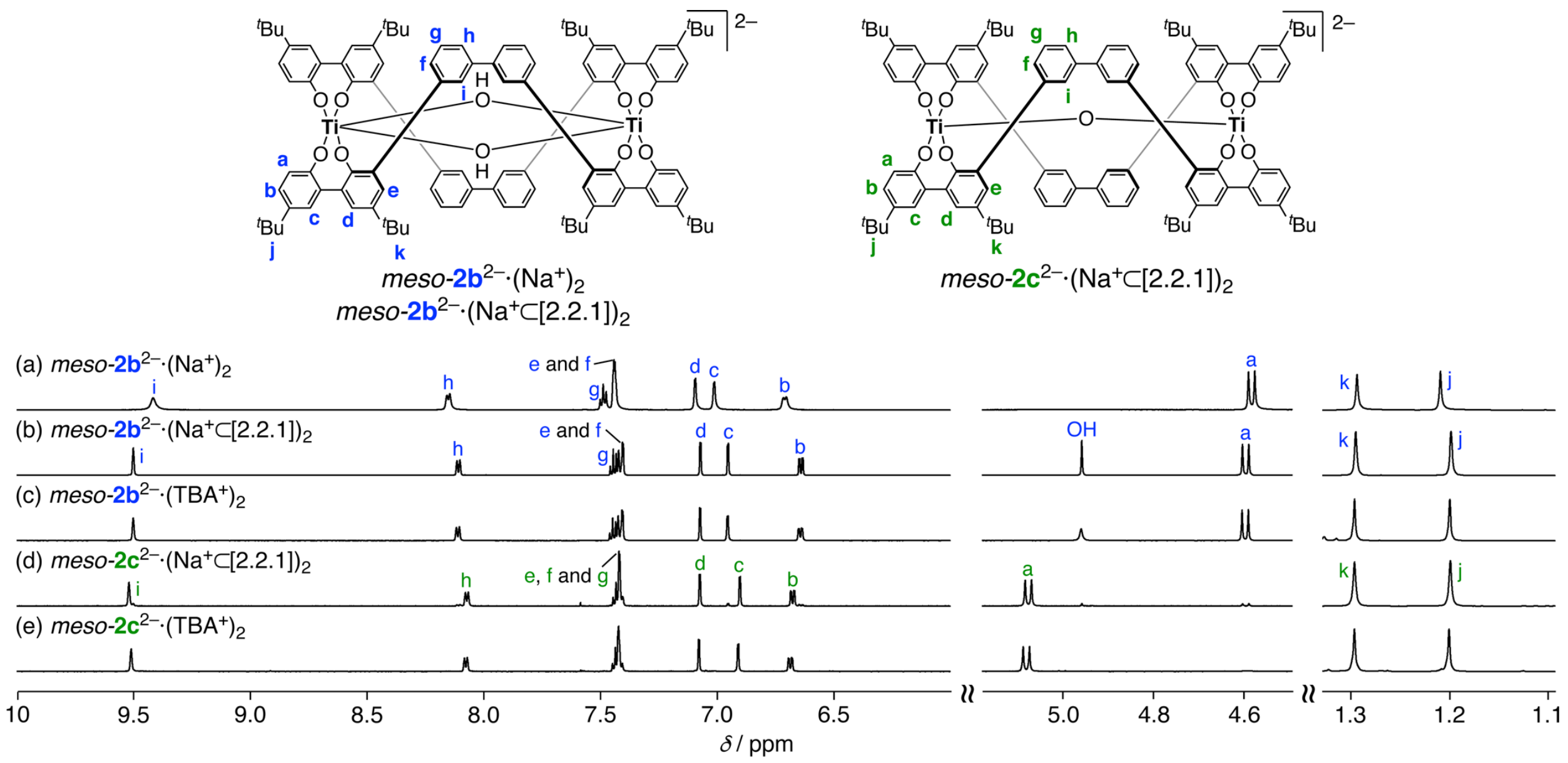

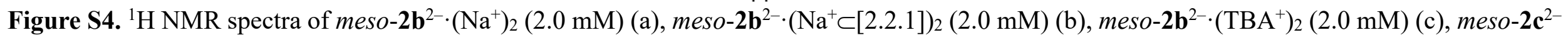

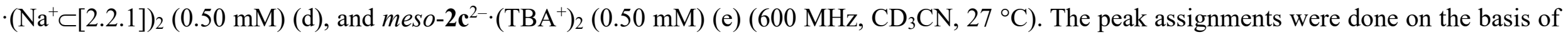
$g C O S Y$ and NOESY spectra of meso-2 $\mathbf{b}^{2-} \cdot\left(\mathrm{Na}^{+}\right)_{2}(2.5 \mathrm{mM})$ and $m e s o-\mathbf{2 c}^{2-} \cdot\left(\mathrm{Na}^{+} \subset[2.2 .1]\right)_{2}(0.50 \mathrm{mM})($ Figures S28-S40). 



Figure S5. Partial ${ }^{13} \mathrm{C}$ NMR spectra of meso-2 $\left.\mathbf{b}^{2-} \cdot\left(\mathrm{Na}^{+}\right)_{2}(2.0 \mathrm{mM})(\mathrm{a}), \operatorname{meso}-\mathbf{2} \mathbf{b}^{2-} \cdot\left(\mathrm{Na}^{+} \subset[2.2 .1]\right)_{2}(2.0 \mathrm{mM})(\mathrm{b}), \mathrm{meso}^{-2 \mathbf{b}^{2-} \cdot(\mathrm{TBA}}\right)_{2}(2.0 \mathrm{mM})(\mathrm{c})$, $m e s o-2 \mathbf{c}^{2-} \cdot\left(\mathrm{Na}^{+} \subset[2.2 .1]\right)_{2}(0.50 \mathrm{mM})(\mathrm{d})$, and meso-2 $\mathbf{c}^{2-} \cdot\left(\mathrm{TBA}^{+}\right)_{2}(0.50 \mathrm{mM})(\mathrm{e})\left(151 \mathrm{MHz}, \mathrm{CD}_{3} \mathrm{CN}, 27^{\circ} \mathrm{C}\right)$. The peak assignments were done on the

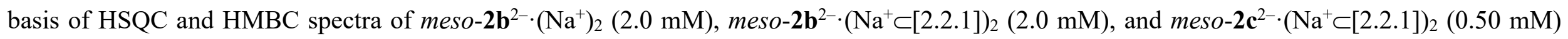
(Figures S41, S42, and S45-S48). 
(a) $\mathrm{rac}-2 \mathrm{a}^{2-} \cdot\left(\mathrm{Na}^{+}\right)_{2}$

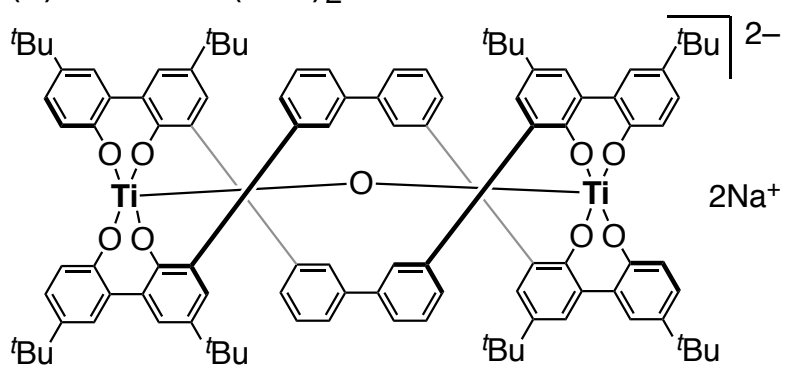

$\left[\mathrm{rac}-2 \mathrm{a} \cdot\left(\mathrm{Na}^{+}\right)_{2}-\mathrm{Na}^{+}\right]^{-}$
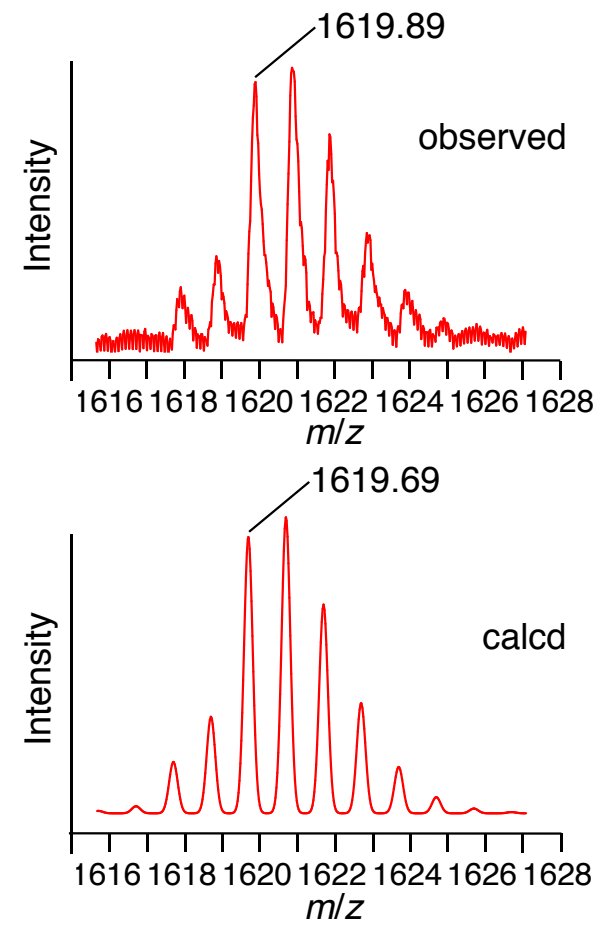

(b) $m e s o-2 b^{2-} \cdot\left(\mathrm{Na}^{+}\right)_{2}$

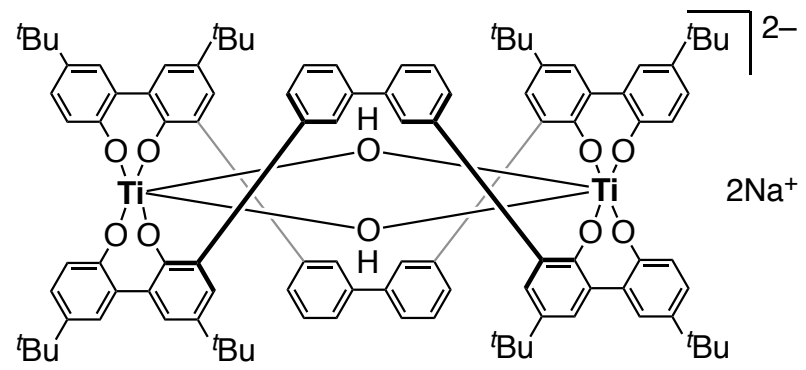

$\left[\text { meso-2b }\left(\mathrm{Na}^{+}\right)_{2}-\mathrm{Na}^{+}\right]^{-}$


Figure S6. Negative mode CSI mass spectra $\left(\mathrm{CH}_{3} \mathrm{CN}\right)$ of $r a c-2 \mathbf{a}^{2-} \cdot\left(\mathrm{Na}^{+}\right)_{2}$ (a) and meso-2 $\mathbf{b}^{2-} \cdot\left(\mathrm{Na}^{+}\right)_{2}(\mathrm{~b})$. 


\section{Thermal Transformation between $r a c-2 a^{2-} \cdot\left(\mathrm{Na}^{+}\right)_{2}$ and meso-2 ${ }^{2-} \cdot\left(\mathrm{Na}^{+}\right)_{2}$ Helicates.}

Procedure for meso- $2 \mathrm{~b}^{2-} \cdot\left(\mathrm{Na}^{+}\right)_{2}$ to $r a c-2 \mathrm{a}^{2-} \cdot\left(\mathrm{Na}^{+}\right)_{2}$ Transformation in Acetonitrile Containing a Small Amount of Water. A solution of meso-2 $\mathbf{b}^{2-} \cdot\left(\mathrm{Na}^{+}\right)_{2}(0.50 \mathrm{mM}, 0.50 \mu \mathrm{mol})$ in dry $\mathrm{CD}_{3} \mathrm{CN}(1.0$ $\mathrm{mL})$ containing a small amount of $\mathrm{H}_{2} \mathrm{O}\left(\left[\mathrm{H}_{2} \mathrm{O}\right]_{0} /\left[\text { meso- } \mathbf{2 b}^{2-} \cdot\left(\mathrm{Na}^{+}\right)_{2}\right]_{0}=\right.$ ca. 10) was prepared in a 5mm NMR tube under argon. The NMR tube was then placed in an oil bath preheated to $75{ }^{\circ} \mathrm{C}$, and the meso-2 $\mathbf{b}^{2-} \cdot\left(\mathrm{Na}^{+}\right)_{2}$ to $\mathrm{rac}-\mathbf{2 a ^ { 2 - }} \cdot\left(\mathrm{Na}^{+}\right)_{2}$ transformation progress was monitored by ${ }^{1} \mathrm{H} \mathrm{NMR}$ spectroscopy at an appropriate time interval (Figure S7). The meso-2 $\mathbf{b}^{2-} \cdot\left(\mathrm{Na}^{+}\right)_{2}$ helicate finally reached an equilibrium after ca. $330 \mathrm{~min}$, yielding a $22: 78$ mixture of $\mathrm{meso}-\mathbf{2} \mathbf{b}^{2-} \cdot\left(\mathrm{Na}^{+}\right)_{2}$ and $\mathrm{rac}$ $\mathbf{2 a}^{2-} \cdot\left(\mathrm{Na}^{+}\right)_{2}$ helicates (Figure S7). In the same way, the meso-2 $\mathbf{b}^{2-} \cdot\left(\mathrm{Na}^{+}\right)_{2}$ to $\mathrm{rac}-\mathbf{2 a}^{2-} \cdot\left(\mathrm{Na}^{+}\right)_{2}$ transformation was performed at $35^{\circ} \mathrm{C}$ in $\mathrm{CD}_{3} \mathrm{CN}$ containing a small amount of water $\left(\left[\mathrm{H}_{2} \mathrm{O}\right]_{0} /[\right.$ meso$\left.\mathbf{2 b}^{2-} \cdot\left(\mathrm{Na}^{+}\right)_{2}\right]_{0}=$ ca. 10) (Figure S18A,Ca).

Procedure for rac- $2 \mathrm{a}^{2-} \cdot\left(\mathrm{Na}^{+}\right)_{2}$ to meso-2 $\mathrm{b}^{2-} \cdot\left(\mathrm{Na}^{+}\right)_{2}$ Transformation in Acetonitrile Containing a Large Amount of Water. A solution of $\mathrm{rac}-\mathbf{2 a}^{2-} \cdot\left(\mathrm{Na}^{+}\right)_{2}(0.49 \mathrm{mM}, 0.36 \mu \mathrm{mol})$ in dry $\mathrm{CD}_{3} \mathrm{CN}(740$ $\mu \mathrm{L})$ containing a small amount of $\mathrm{H}_{2} \mathrm{O}\left(\left[\mathrm{H}_{2} \mathrm{O}\right]_{0} /\left[\mathrm{rac}-\mathbf{2 a}^{2-} \cdot\left(\mathrm{Na}^{+}\right)_{2}\right]_{0}=\right.$ ca. 40$)$ was prepared in a 5-mm NMR tube under argon (Figure S8a). To this was added ca. 1000 equiv water $(7.0 \mu \mathrm{L}, 0.38 \mathrm{mmol})$ (Figure S8b). After heating the solution at $75{ }^{\circ} \mathrm{C}$ for $30 \mathrm{~min}$, its ${ }^{1} \mathrm{H}$ NMR spectrum was measured (Figure $4 \mathrm{Cb}$ ). In the same way, the $\mathrm{rac}-\mathbf{2} \mathbf{a}^{2-} \cdot\left(\mathrm{Na}^{+}\right)_{2}$ to $m e s o-\mathbf{2 b}^{2-} \cdot\left(\mathrm{Na}^{+}\right)_{2}$ transformation was performed at $35{ }^{\circ} \mathrm{C}$ in $\mathrm{CD}_{3} \mathrm{CN}$ containing a large amount of water $\left(\left[\mathrm{H}_{2} \mathrm{O}\right]_{0} /\left[\mathrm{rac}-\mathbf{2 a}^{2-} \cdot\left(\mathrm{Na}^{+}\right)_{2}\right]_{0}>\right.$ ca. 1000$)$ (Figure $\mathrm{S} 18 \mathrm{~B}, \mathrm{Cb})$. 

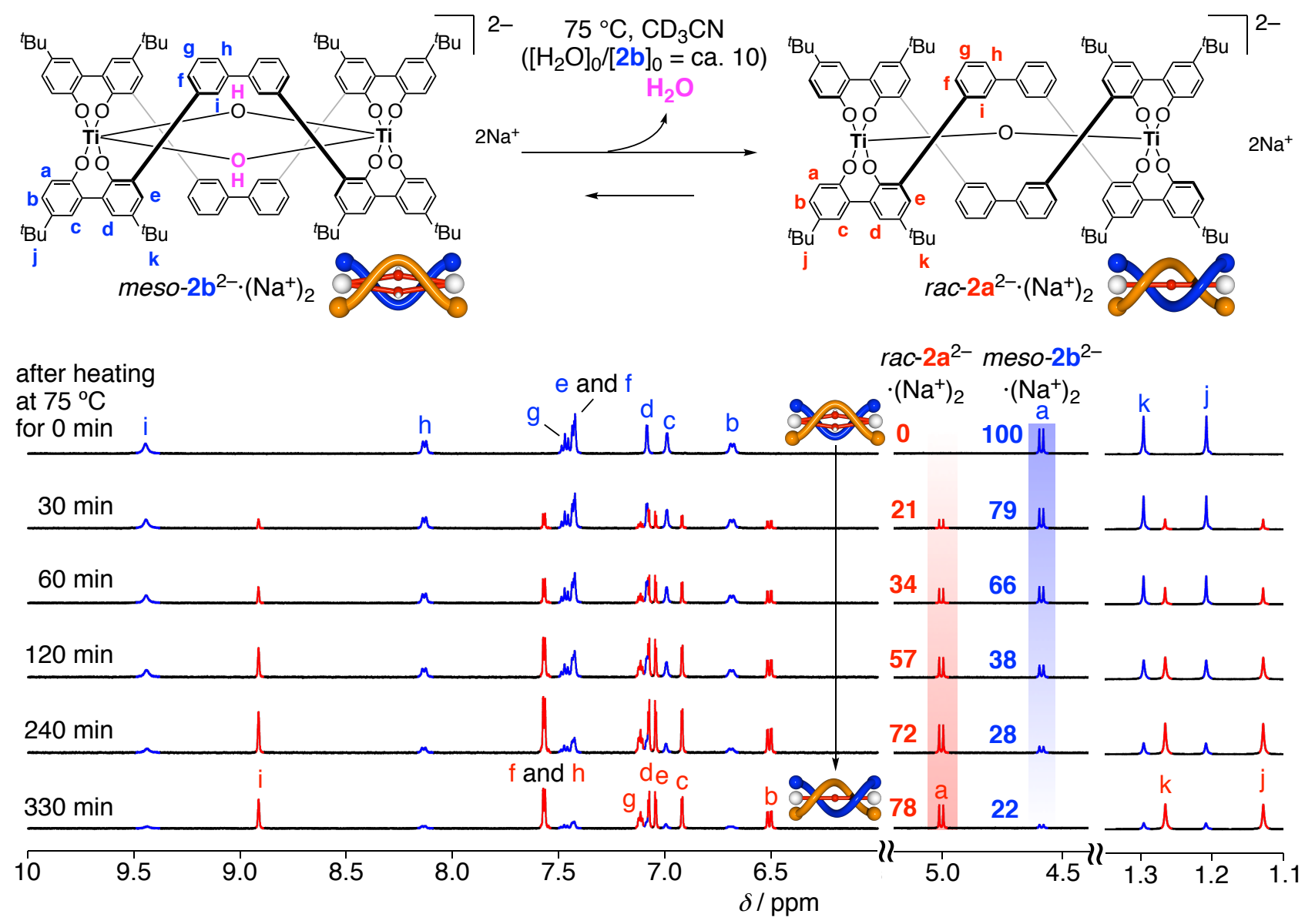

Figure S7. Time-dependent ${ }^{1} \mathrm{H}$ NMR spectral changes of meso-2 $\mathbf{b}^{2-} \cdot\left(\mathrm{Na}^{+}\right)_{2}\left(500 \mathrm{MHz}, \mathrm{CD}_{3} \mathrm{CN}\right.$ containing $\mathrm{H}_{2} \mathrm{O}\left(\left[\mathrm{H}_{2} \mathrm{O}\right]_{0} /\left[\text { meso-2 } \mathbf{b}^{2-} \cdot\left(\mathrm{Na}^{+}\right)_{2}\right]_{0}=\right.$ ca. 10$\left.), 0.50 \mathrm{mM}\right)$ upon heating at $75^{\circ} \mathrm{C}$, measured at $25{ }^{\circ} \mathrm{C}$ (see Figure 4D for the meso-to-racemo transformation kinetics). 

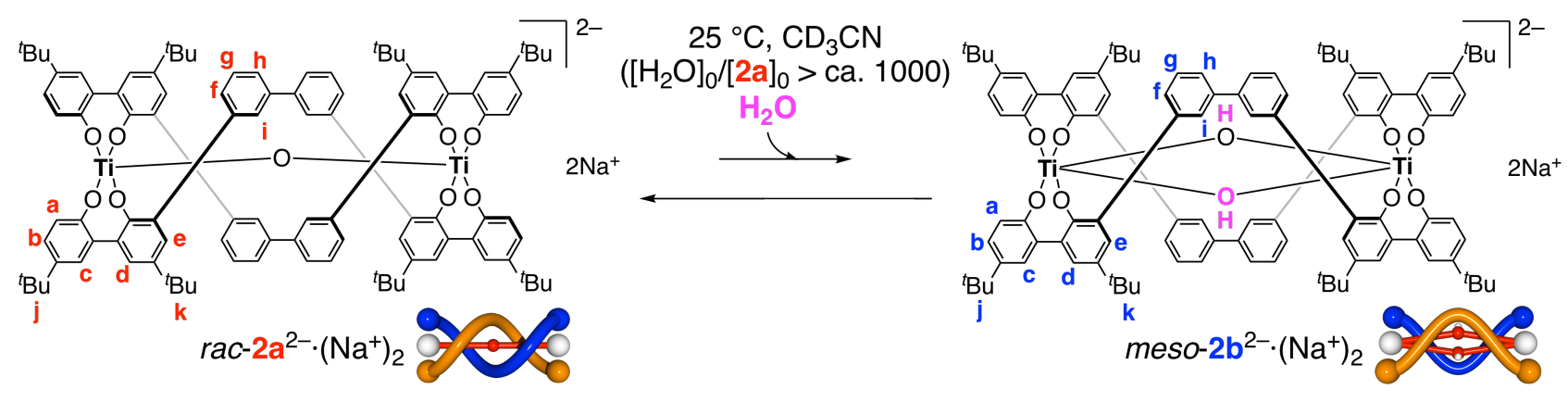

(a) $\mathrm{rac}-2 \mathrm{a}^{2-} \cdot\left(\mathrm{Na}^{+}\right)_{2}$ rac-2a $\mathrm{a}^{2-} \quad$ meso- $2 \mathrm{~b}^{2-}$ (containing ca. 40 equiv of water)
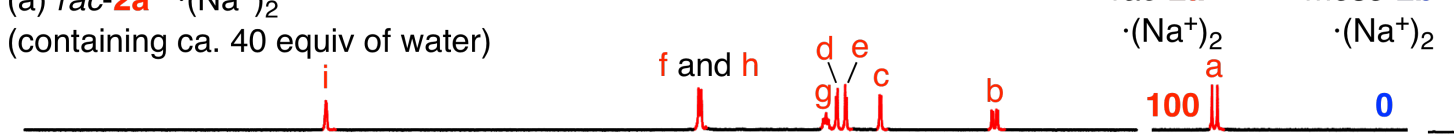

(b) (a) + water > ca. 1000 equiv

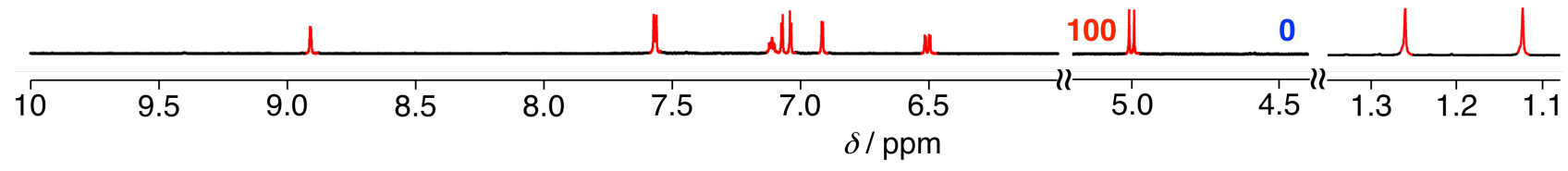

Figure S8. ${ }^{1} \mathrm{H}$ NMR spectra of $r a c-2 \mathbf{a}^{2-} \cdot\left(\mathrm{Na}^{+}\right)_{2}\left(500 \mathrm{MHz}, \mathrm{CD}_{3} \mathrm{CN}\right.$ containing $\mathrm{H}_{2} \mathrm{O}\left(\left[\mathrm{H}_{2} \mathrm{O}\right]_{0} /[\mathrm{rac}-\right.$ $\left.2 \mathbf{a}^{2-} \cdot\left(\mathrm{Na}^{+}\right)_{2}\right]_{0}=$ ca. 40$\left.), 0.49 \mathrm{mM}\right)$ before (a) and after the addition of a large excess of $\mathrm{H}_{2} \mathrm{O}$ $\left(\left[\mathrm{H}_{2} \mathrm{O}\right]_{0} /\left[\mathrm{rac}-\mathbf{2} \mathbf{a}^{2-} \cdot\left(\mathrm{Na}^{+}\right)_{2}\right]_{0}>\right.$ ca. 1000$)$ at $25^{\circ} \mathrm{C}(\mathrm{b})$. 


\section{4-1. Transformation between $m e s o-2 b^{2-} \cdot\left(\mathrm{Na}^{+}\right)_{2}$ and $m e s o-2 \mathrm{c}^{2-} \cdot\left(\mathrm{Na}^{+}\right)_{2}$ Helicates.}

Procedure for meso- $2 \mathrm{~b}^{2-} \cdot\left(\mathrm{Na}^{+}\right)_{2}$ to meso- $2 \mathrm{c}^{2-} \cdot\left(\mathrm{Na}^{+}\right)_{2}$ Transformation in Dry Acetonitrile in the Absence of Cryptand[2.2.1] (method I). A solution of meso-2 $\mathbf{b}^{2-} \cdot\left(\mathrm{Na}^{+}\right)_{2}(0.50 \mathrm{mM}, 0.34 \mu \mathrm{mol})$ in dry $\mathrm{CD}_{3} \mathrm{CN}(690 \mu \mathrm{L})$ containing a small amount of $\mathrm{H}_{2} \mathrm{O}\left(\left[\mathrm{H}_{2} \mathrm{O}\right] /\left[\right.\right.$ meso-2 $\left.\mathbf{b}^{2-} \cdot\left(\mathrm{Na}^{+}\right)_{2}\right]=$ ca. 5) was prepared in a 5-mm NMR tube under argon. Subsequently, 3A molecular sieves (ca. $60 \mathrm{mg}$ ) were added under nitrogen to further dry the solvent. The NMR tube was then sealed at $-78{ }^{\circ} \mathrm{C}$ under vacuum and placed in a cooling bath precooled at $-30{ }^{\circ} \mathrm{C}$ for 2 days for maintaining exhaustively dry condition. We noted that the transformation did not take place at all at $-30^{\circ} \mathrm{C}$. After removal of the molecular sieves fixed in the end of the NMR tube by heat sealing carefully under vacuum, the NMR tube was placed in an oil bath preheated to $75{ }^{\circ} \mathrm{C}$. The meso-2 $\mathbf{b}^{2-} \cdot\left(\mathrm{Na}^{+}\right)_{2}$ to meso-2 $\mathbf{c}^{2-} \cdot\left(\mathrm{Na}^{+}\right)_{2}$ transformation progress was monitored by ${ }^{1} \mathrm{H}$ NMR spectroscopy in dry $\mathrm{CD}_{3} \mathrm{CN}\left(\left[\mathrm{H}_{2} \mathrm{O}\right] /[\right.$ meso$\left.\mathbf{2 b}^{2-} \cdot\left(\mathrm{Na}^{+}\right)_{2}\right]=$ ca. 0.44$)$ at $75{ }^{\circ} \mathrm{C}$ at an appropriate time interval (Figure S10). The meso-2 $\mathbf{b}^{2-} \cdot\left(\mathrm{Na}^{+}\right)_{2}$ helicate finally reached an equilibrium after ca. $5 \mathrm{~min}$, yielding a 83:17 mixture of meso-2 $\mathbf{b}^{2-} \cdot\left(\mathrm{Na}^{+}\right)_{2}$ and $m e s o-2 c^{2-} \cdot\left(\mathrm{Na}^{+}\right)_{2}$ helicates (Figure $\left.\mathrm{S} 10\right)$.

\section{Procedure for meso- $2 \mathrm{~b}^{2-} \cdot\left(\mathrm{Na}^{+}\right)_{2}$ to $m e s o-2 \mathrm{c}^{2-} \cdot\left(\mathrm{Na}^{+}\right)_{2}$ Transformation in Dry Acetonitrile in the} Presence of Cryptand[2.2.1] (method II). A solution of meso-2 $\mathbf{b}^{2-} \cdot\left(\mathrm{Na}^{+}\right)_{2}(0.53 \mathrm{mM}, 0.36 \mu \mathrm{mol})$ in dry $\mathrm{CD}_{3} \mathrm{CN}(680 \mu \mathrm{L})$ containing a small amount of $\mathrm{H}_{2} \mathrm{O}\left(\left[\mathrm{H}_{2} \mathrm{O}\right] /\left[\right.\right.$ meso-2 $\left.\mathbf{b}^{2-} \cdot\left(\mathrm{Na}^{+}\right)_{2}\right]=$ ca. 12$)$ was prepared in a 5-mm NMR tube under argon. To this was added a solution of cryptand[2.2.1] in dry $\mathrm{CD}_{3} \mathrm{CN}(79.1 \mathrm{mM}, 19 \mu \mathrm{L}, 1.5 \mu \mathrm{mol})$ under argon to afford meso-2 $\mathbf{b}^{2-} \cdot\left(\mathrm{Na}^{+} \subset[2.2 .1]\right)_{2}$. Subsequently, 3A molecular sieves (ca. $60 \mathrm{mg}$ ) were added under nitrogen to further dry the solvent. The NMR tube was then sealed at $-78^{\circ} \mathrm{C}$ under vacuum and placed in a cooling bath precooled at $-30{ }^{\circ} \mathrm{C}$ for 2 days for maintaining exhaustively dry condition. We noted that the transformation did not take place at all at $-30{ }^{\circ} \mathrm{C}$. After the molecular sieves were fixed in the end of the NMR tube, the NMR tube was placed in an oil bath preheated to $75^{\circ} \mathrm{C}$ and its ${ }^{1} \mathrm{H}$ NMR spectrum was measured in dry $\mathrm{CD}_{3} \mathrm{CN}$ $\left(\left[\mathrm{H}_{2} \mathrm{O}\right] /\left[\right.\right.$ meso-2 $\left.\mathbf{b}^{2-} \cdot\left(\mathrm{Na}^{+} \subset[2.2 .1]\right)_{2}\right]=$ ca. 0.48$)$ at $75^{\circ} \mathrm{C}$ after $5 \mathrm{~min}$ (Figure S11a) to follow the meso$\mathbf{2 b}^{2-} \cdot\left(\mathrm{Na}^{+} \subset[2.2 .1]\right)_{2}$ to $m e s o-2 \mathbf{c}^{2-} \cdot\left(\mathrm{Na}^{+} \subset[2.2 .1]\right)_{2}$ transformation. The NMR tube was then place in a cooling bath precooled at $-30{ }^{\circ} \mathrm{C}$ for several hours in order to remove the in situ generated water during the transformation with the molecular sieves, which had been placed in the helicate solution. This meso-2 $\mathbf{b}^{2-} \cdot\left(\mathrm{Na}^{+} \subset[2.2 .1]\right)_{2}$ to meso-2 $\mathbf{c}^{2-} \cdot\left(\mathrm{Na}^{+} \subset[2.2 .1]\right)_{2}$ transformation at $75{ }^{\circ} \mathrm{C}$ followed by removal of the in situ generated water with the molecular sieves was repeated at an appropriate time 
interval. The meso-2 $\mathbf{b}^{2-} \cdot\left(\mathrm{Na}^{+} \subset[2.2 .1]\right)_{2}$ helicate finally reached an equilibrium after ca. $90 \mathrm{~min}$, yielding a 6:94 mixture of meso-2 $\mathbf{b}^{2-} \cdot\left(\mathrm{Na}^{+} \subset[2.2 .1]\right)_{2}$ and $m e s o-\mathbf{2 c}^{2-} \cdot\left(\mathrm{Na}^{+} \subset[2.2 .1]\right)_{2}$ helicates (Figure S11).

Procedure for Reversible Transformation between meso- $2 b^{2-} \cdot\left(\mathrm{Na}^{+}\right)_{2}$ and $m e s o-2 c^{2-} \cdot\left(\mathrm{Na}^{+}\right)_{2}$ Helicates in Dry Acetonitrile in the Presence of Cryptand[2.2.1]. A solution of meso-2 $\mathbf{b}^{2-} \cdot\left(\mathrm{Na}^{+}\right)_{2}$ $(0.52 \mathrm{mM}, 0.36 \mu \mathrm{mol})$ in dry $\mathrm{CD}_{3} \mathrm{CN}(700 \mu \mathrm{L})$ containing a small amount of $\mathrm{H}_{2} \mathrm{O}\left(\left[\mathrm{H}_{2} \mathrm{O}\right] /[\right.$ meso$\left.\mathbf{2 b}^{2-} \cdot\left(\mathrm{Na}^{+}\right)_{2}\right]=$ ca. 6) was prepared in a 5-mm NMR tube under argon. To this was added a solution of cryptand[2.2.1] in dry $\mathrm{CD}_{3} \mathrm{CN}(78.5 \mathrm{mM}, 20 \mu \mathrm{L}, 1.6 \mu \mathrm{mol})$ under argon to afford meso$\mathbf{2 b}^{2-} \cdot\left(\mathrm{Na}^{+} \subset[2.2 .1]\right)_{2}$. Subsequently, 3A molecular sieves (ca. $60 \mathrm{mg}$ ) were added under nitrogen to further dry the solvent. The NMR tube was then sealed at $-78{ }^{\circ} \mathrm{C}$ under vacuum and placed in a cooling bath precooled at $-30{ }^{\circ} \mathrm{C}$ for 2 days for maintaining exhaustively dry condition. We noted that the transformation did not take place at all at $-30{ }^{\circ} \mathrm{C}$. After removal of the molecular sieves fixed in the end of the NMR tube by heat sealing carefully under vacuum, the NMR tube was placed in an

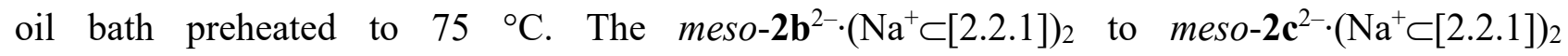
transformation progress was monitored by ${ }^{1} \mathrm{H}$ NMR spectroscopy in dry $\mathrm{CD}_{3} \mathrm{CN}\left(\left[\mathrm{H}_{2} \mathrm{O}\right] /[\right.$ meso$\left.\mathbf{2 b}^{2-} \cdot\left(\mathrm{Na}^{+} \subset[2.2 .1]\right)_{2}\right]_{0}=$ ca. 0.42$)$ at $75^{\circ} \mathrm{C}$ at an appropriate time interval (Figure S12a). The meso$\mathbf{2 b}^{2-} \cdot\left(\mathrm{Na}^{+} \subset[2.2 .1]\right)_{2}$ helicate finally reached an equilibrium after ca. $90 \mathrm{~min}$, yielding a 17:83 mixture



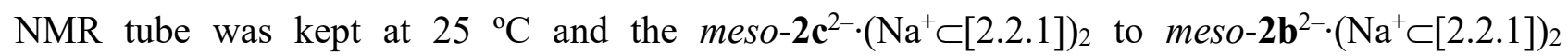
transformation progress was then monitored by ${ }^{1} \mathrm{H}$ NMR spectroscopy at an appropriate time interval

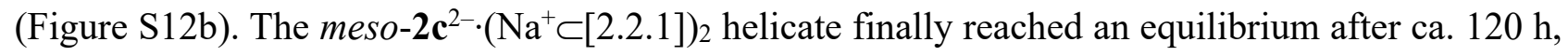
yielding a 22:78 mixture of meso-2 $\mathbf{c}^{2-} \cdot\left(\mathrm{Na}^{+} \subset[2.2 .1]\right)_{2}$ and $m e s o-\mathbf{2 b}^{2-} \cdot\left(\mathrm{Na}^{+} \subset[2.2 .1]\right)_{2}$ helicates (Figure S12d). 

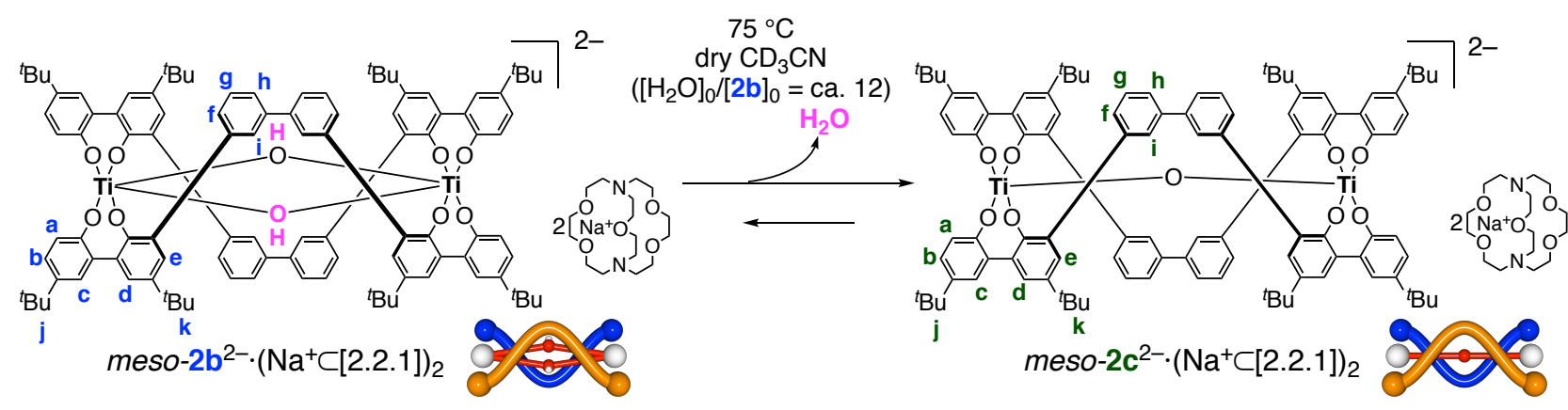

(a) after heating at $75^{\circ} \mathrm{C}$ for $0 \mathrm{~min}$

meso-2c $\mathrm{c}^{2-} \quad \mathrm{rac}-2 \mathrm{a}^{2-} \quad$ meso-2 $\mathrm{b}^{2-}$ $\cdot\left(\mathrm{Na}^{+} \subset[2.2 .1]\right)_{2} \cdot\left(\mathrm{Na}^{+} \subset[2.2 .1]\right)_{2} \cdot\left(\mathrm{Na}^{+} \subset[2.2 .1]\right)_{2}$

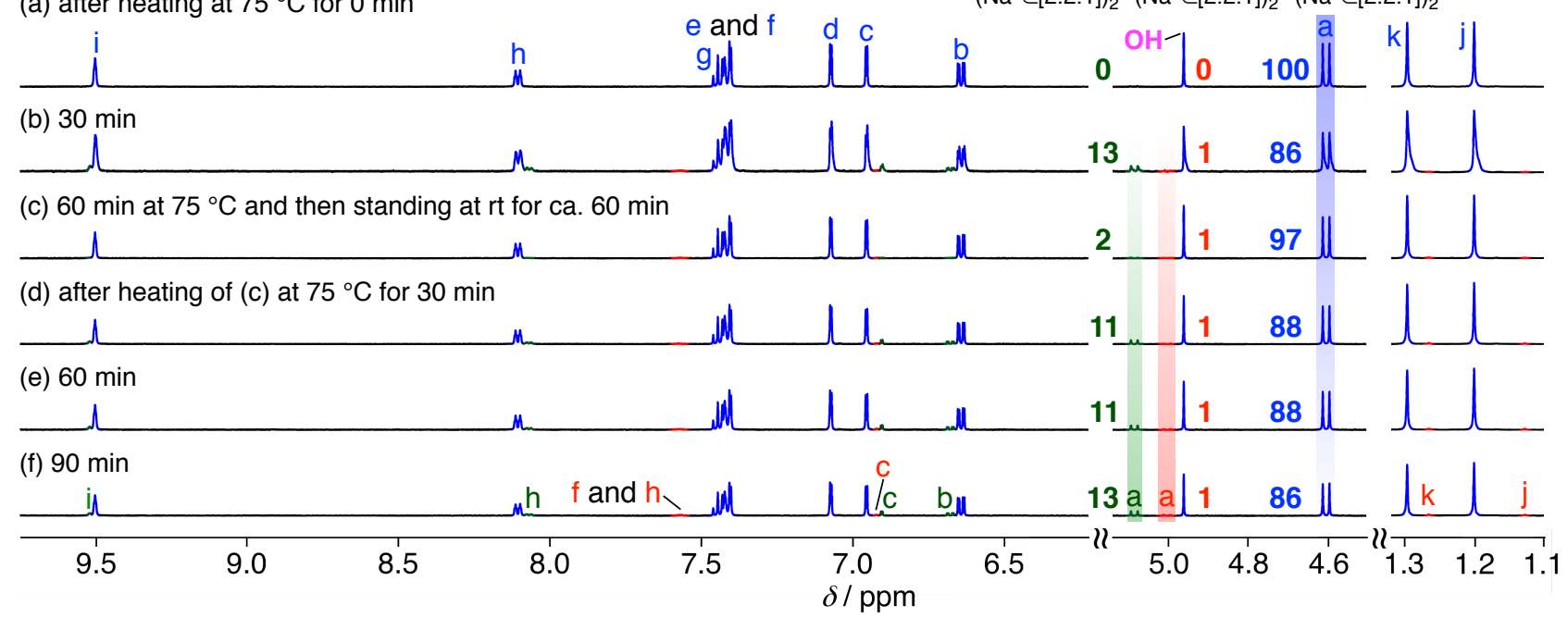

Figure S9. Time-dependent ${ }^{1} \mathrm{H}$ NMR spectral changes of meso-2 ${ }^{2-} \cdot\left(\mathrm{Na}^{+} \subset[2.2 .1]\right)_{2}(500 \mathrm{MHz}$, $\mathrm{CD}_{3} \mathrm{CN}$ containing $\mathrm{H}_{2} \mathrm{O}\left(\left[\mathrm{H}_{2} \mathrm{O}\right]_{0} /\left[\text { meso- } \mathbf{2 b}^{2-} \cdot\left(\mathrm{Na}^{+} \subset[2.2 .1]\right)_{2}\right]_{0}=\right.$ ca. 12), $\left.0.50 \mathrm{mM}\right)$ in the presence of 4 equiv of cryptand[2.2.1] before (a) and after heating at $75^{\circ} \mathrm{C}$ for 30 (b and d), 60 (e), and $90 \mathrm{~min}$, measured at $25{ }^{\circ} \mathrm{C}$ (f). The ${ }^{1} \mathrm{H}$ NMR spectrum after heating at $75^{\circ} \mathrm{C}$ for $60 \mathrm{~min}$ and then standing at room temperature for $60 \mathrm{~min}$ is also shown in (c). 

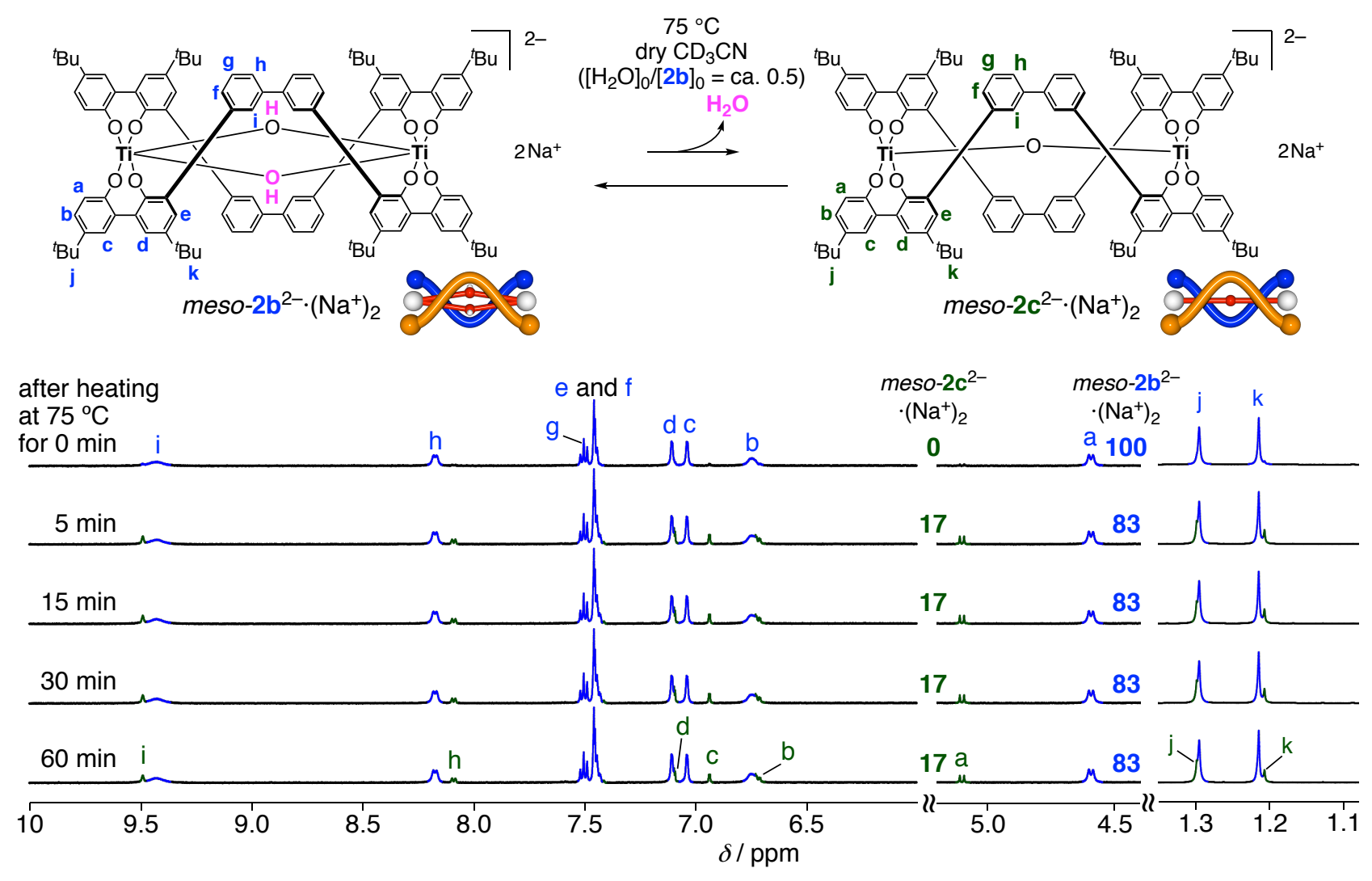

Figure S10. Time-dependent ${ }^{1} \mathrm{H}$ NMR spectral changes of meso-2 $\mathbf{b}^{2-} \cdot\left(\mathrm{Na}^{+}\right)_{2}(500 \mathrm{MHz}$, anhydrous $\mathrm{CD}_{3} \mathrm{CN},\left[\mathrm{H}_{2} \mathrm{O}\right]_{0} /\left[\text { meso-2 } \mathbf{b}^{2-} \cdot\left(\mathrm{Na}^{+}\right)_{2}\right]_{0}=$ ca. $\left.0.5,0.5 \mathrm{mM}\right)$ upon heating at $75{ }^{\circ} \mathrm{C}$, measured at $25{ }^{\circ} \mathrm{C}$. 


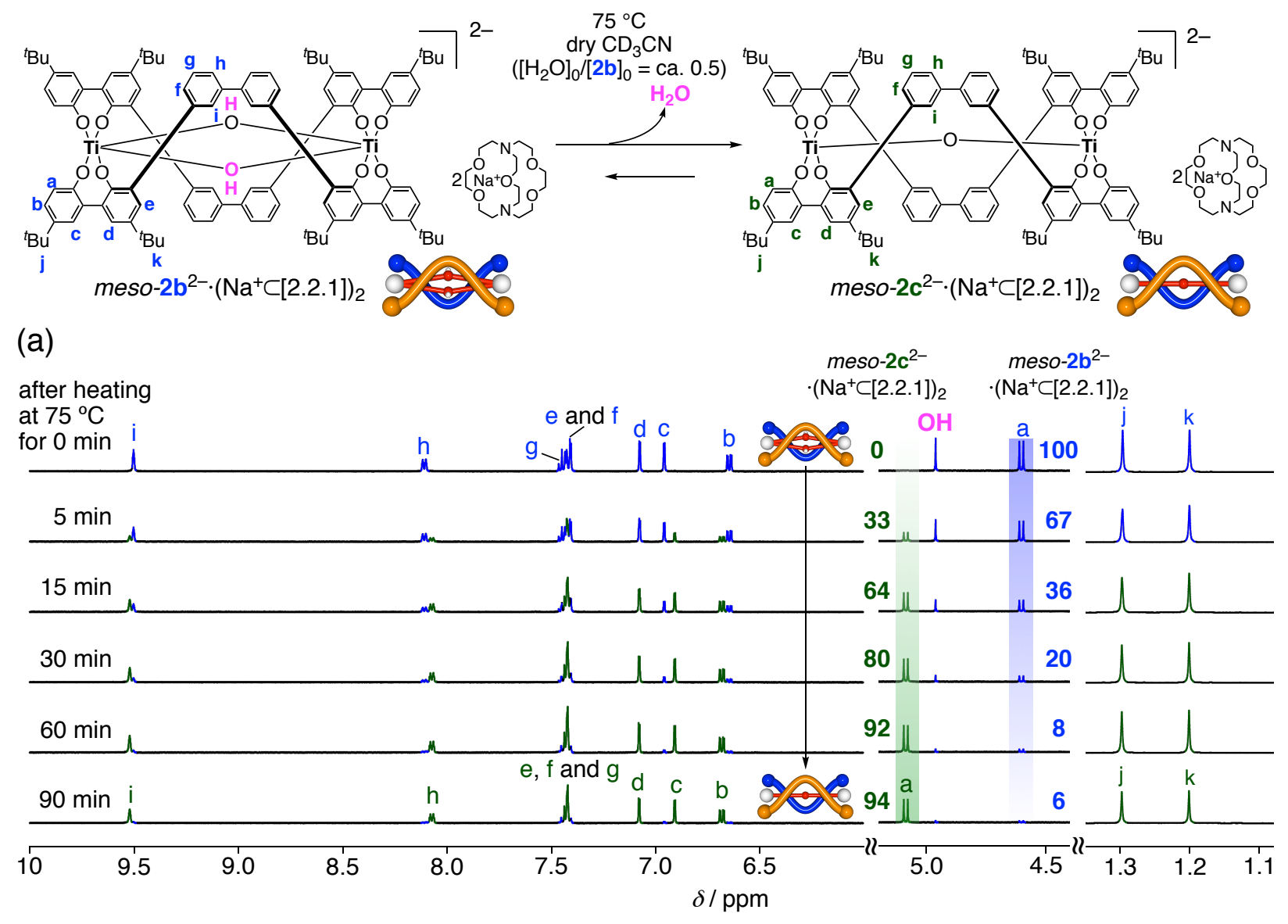

(b)

(c) $\frac{[2 \mathrm{~b}]}{[2 \mathrm{~b}]+[2 \mathrm{c}]}=\frac{k_{-1}}{k_{1}+k_{-1}}+\frac{k_{1}}{k_{1}+k_{-1}} \exp \left[-\left(k_{1}+k_{-1}\right) t\right]$
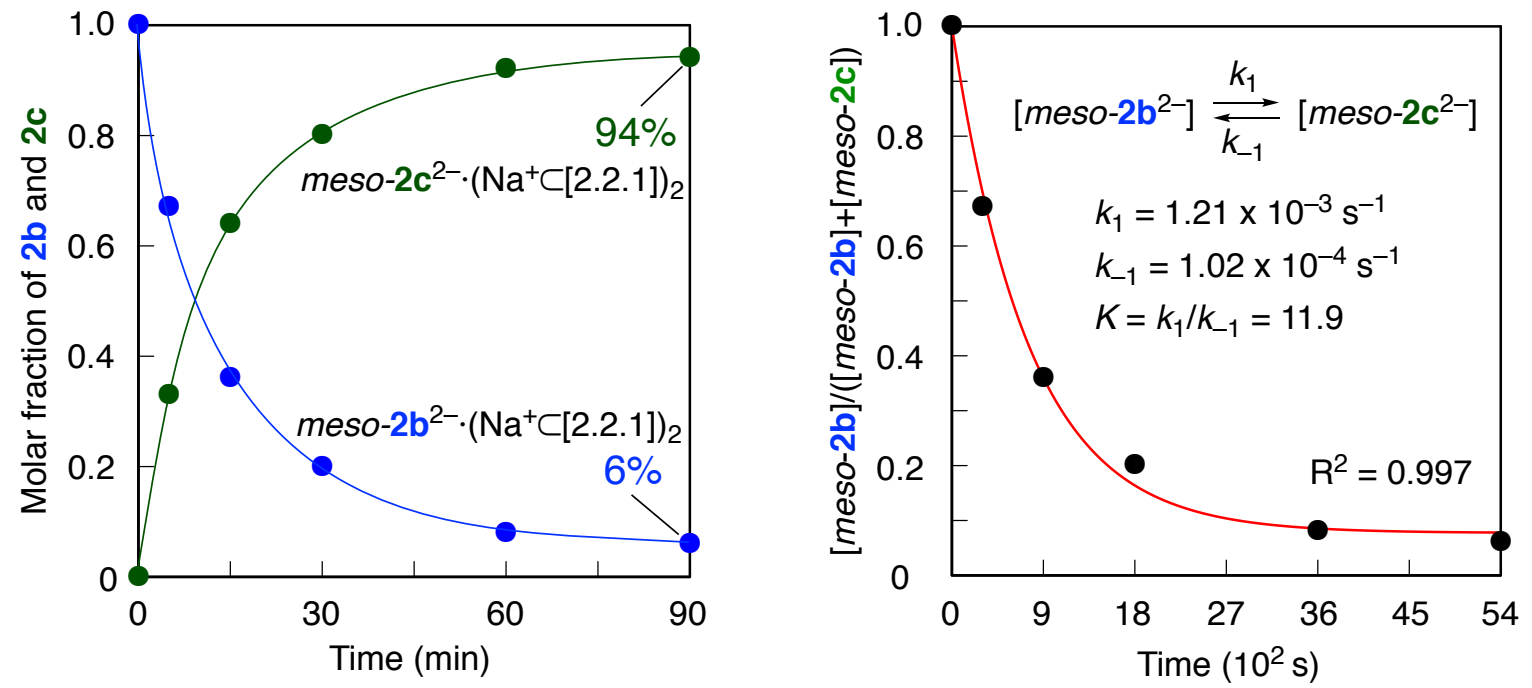

Figure S11. (a) Time-dependent ${ }^{1} \mathrm{H}$ NMR spectral changes of meso-2 $\mathbf{b}^{2-} \cdot\left(\mathrm{Na}^{+}\right)_{2}(500 \mathrm{MHz}$, anhydrous $\mathrm{CD}_{3} \mathrm{CN},\left[\mathrm{H}_{2} \mathrm{O}\right]_{0} /\left[\text { meso-2 } \mathbf{b}^{2-} \cdot\left(\mathrm{Na}^{+}\right)_{2}\right]_{0}=$ ca. $\left.0.5,0.5 \mathrm{mM}\right)$ in the presence of 4 equiv of cryptand[2.2.1] upon heating at $75{ }^{\circ} \mathrm{C}$, measured at $25^{\circ} \mathrm{C}$. The in situ generated water during the transformation was removed with $3 \mathrm{~A}$ molecular sieves before each ${ }^{1} \mathrm{H}$ NMR measurement (see Section 4-1 in the SI). (b) Plots of the molar fractions of meso-2 $\mathbf{b}^{2-} \cdot\left(\mathrm{Na}^{+} \subset[2.2 .1]\right)_{2}$ and meso$\mathbf{2 c}^{2-} \cdot\left(\mathrm{Na}^{+} \subset[2.2 .1]\right)_{2}$ as a function of time during the meso-2 $\mathbf{b}^{2-}$-to-meso-2 $\mathbf{c}^{2-}$ transformation. The solid lines are drawn to guide the eyes. (c) Transformation kinetics of meso-2 $\mathbf{b}^{2-} \cdot\left(\mathrm{Na}^{+}\right)_{2}$. 


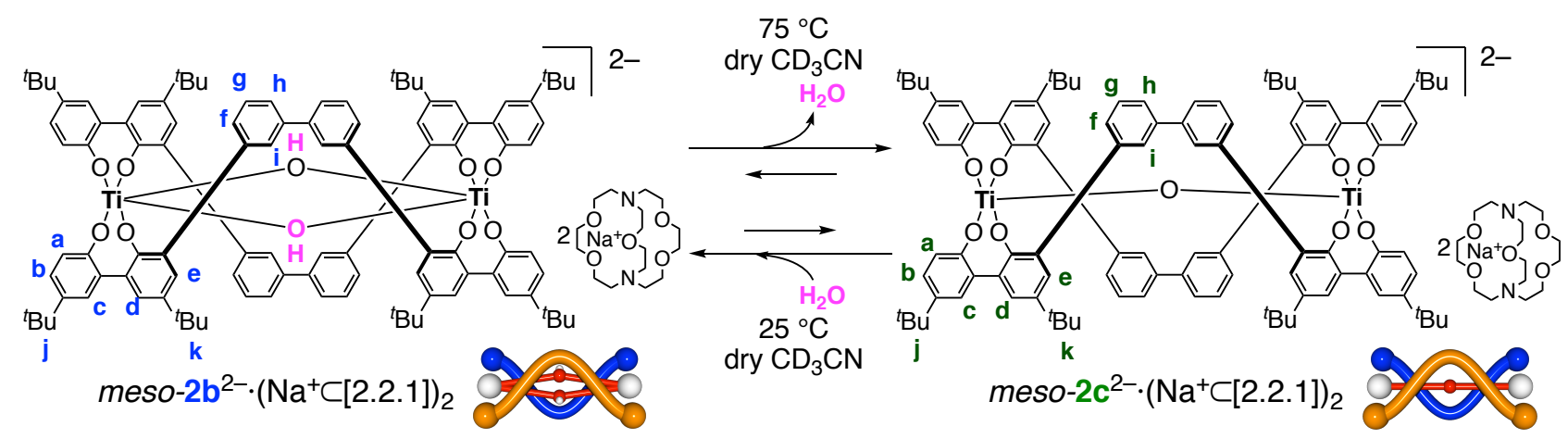

(a)

after heating

at $75^{\circ} \mathrm{C}$

for 0 min

i

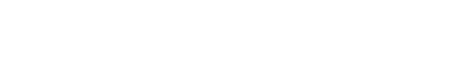

meso-2 $\mathrm{c}^{2-} \quad$ meso-2 $\mathrm{b}^{2-}$ $\cdot\left(\mathrm{Na}^{+} \subset[2.2 .1]\right)_{2} \quad \cdot\left(\mathrm{Na}^{+} \subset[2.2 .1]\right)_{2}$

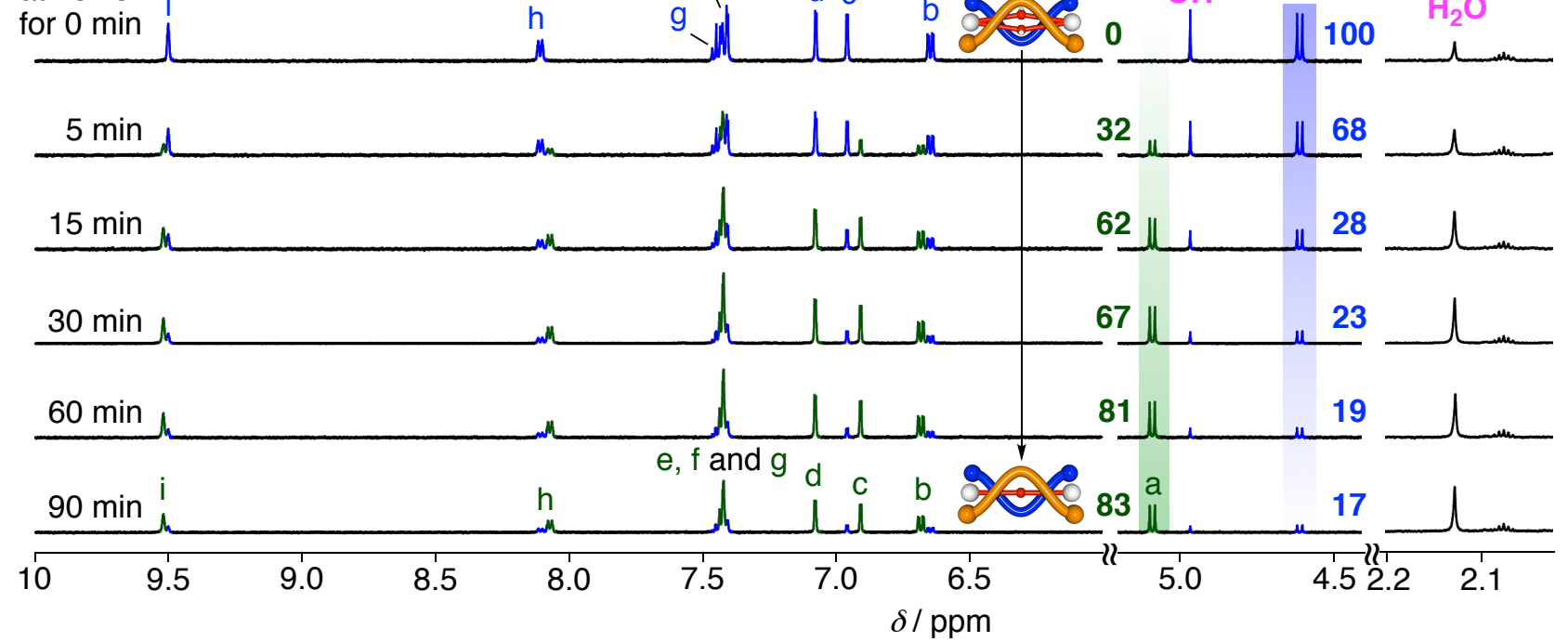

(b)



(Figure S12 to be continued) 
(c)

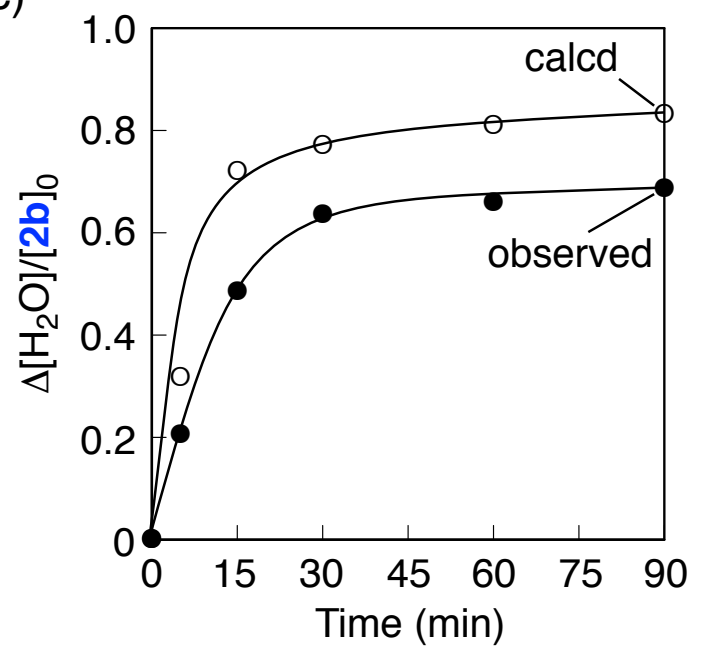

(d)

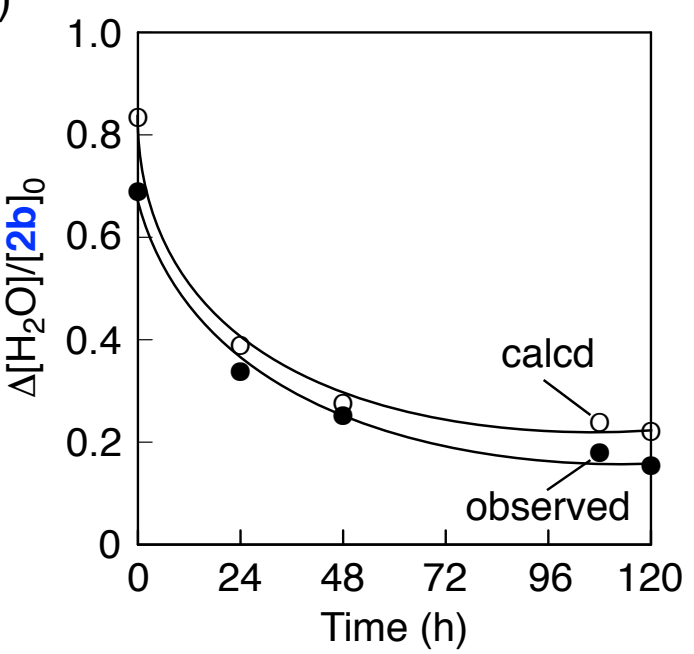

Figure S12. Time-dependent ${ }^{1} \mathrm{H}$ NMR spectral changes of $m e s o-2 \mathbf{b}^{2-} \cdot\left(\mathrm{Na}^{+} \subset[2.2 .1]\right)_{2}(500 \mathrm{MHz}$, dry $\left.\mathrm{CD}_{3} \mathrm{CN}\left(\left[\mathrm{H}_{2} \mathrm{O}\right]_{0} /\left[\text { meso-2 } \mathbf{b}^{2-} \cdot\left(\mathrm{Na}^{+} \subset[2.2 .1]\right)_{2}\right]_{0}=0.40\right), 0.50 \mathrm{mM}\right)$ in the presence of 4 equiv of cryptand[2.2.1] upon heating at $75^{\circ} \mathrm{C}$, measured at $25^{\circ} \mathrm{C}$ (a) followed by standing at $25^{\circ} \mathrm{C}(\mathrm{b})$. (c,d) Time-dependent changes in the observed and calculated amounts of in situ generated water (c) and in situ consumed water $(\mathrm{d})\left(\Delta\left[\mathrm{H}_{2} \mathrm{O}\right] /\left[\text { meso-2 } \mathbf{b}^{2-} \cdot\left(\mathrm{Na}^{+} \subset[2.2 .1]\right)_{2}\right]_{0}\right)$ estimated by ${ }^{1} \mathrm{H}$ NMR spectral changes (see Figure $\mathrm{S} 9 \mathrm{a}$ and $\mathrm{b}$, respectively) during the transformation between meso-

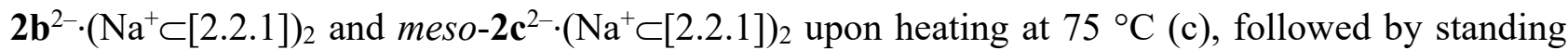
the sample at $25^{\circ} \mathrm{C}(\mathrm{d})$. The solid lines are drawn to guide the eyes. 


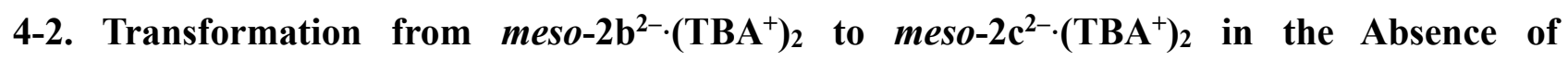
Cryptand[2.2.1]. A solution of meso-2 $\mathbf{b}^{2-} \cdot\left(\mathrm{TBA}^{+}\right)_{2}(0.50 \mathrm{mM}, 0.27 \mu \mathrm{mol})$ in dry $\mathrm{CD}_{3} \mathrm{CN}(530 \mu \mathrm{L})$ containing a small amount of $\mathrm{H}_{2} \mathrm{O}\left(\left[\mathrm{H}_{2} \mathrm{O}\right]_{0} /\left[\text { meso-2 } \mathbf{b}^{2-} \cdot\left(\mathrm{TBA}^{+}\right)_{2}\right]_{0}=\right.$ ca. 5) was prepared in a 5-mm NMR tube under argon. Subsequently, 3A molecular sieves (ca. $60 \mathrm{mg}$ ) were added under nitrogen to further dry the solvent. The NMR tube was then sealed at $-78^{\circ} \mathrm{C}$ under vacuum. We noted that the transformation did not take place at all at $-30^{\circ} \mathrm{C}$. After the molecular sieves were fixed in the end of the NMR tube, the NMR tube was placed in an oil bath preheated to $75^{\circ} \mathrm{C}$ and its ${ }^{1} \mathrm{H}$ NMR spectrum was measured in dry $\mathrm{CD}_{3} \mathrm{CN}\left(\left[\mathrm{H}_{2} \mathrm{O}\right]_{0} /\left[\text { meso- } \mathbf{2 b}^{2-} \cdot\left(\mathrm{TBA}^{+}\right)_{2}\right]_{0}=\right.$ ca. 0.5$)$ at $75^{\circ} \mathrm{C}$ to follow the meso$\mathbf{2 b}^{2-} \cdot\left(\mathrm{TBA}^{+}\right)_{2}$ to meso-2 $\mathbf{c}^{2-} \cdot\left(\mathrm{TBA}^{+}\right)_{2}$ transformation. The NMR tube was then place in a cooling bath precooled at $-30{ }^{\circ} \mathrm{C}$ for several hours in order to remove the in situ generated water during the transformation with the molecular sieves, which had been placed in the helicate solution. This meso$\mathbf{2 b}^{2-} \cdot\left(\mathrm{TBA}^{+}\right)_{2}$ to meso-2 $\mathbf{c}^{2-} \cdot\left(\mathrm{TBA}^{+}\right)_{2}$ transformation at $75{ }^{\circ} \mathrm{C}$ followed by removal of the in situ generated water with the molecular sieves was repeated at an appropriate time interval. The meso$\mathbf{2 b}^{2-} \cdot\left(\mathrm{TBA}^{+}\right)_{2}$ helicate finally reached an equilibrium after ca. $11 \mathrm{~h}$, yielding a 3:97 mixture of meso$\mathbf{2 b}^{2-} \cdot\left(\mathrm{TBA}^{+}\right)_{2}$ and $m e s o-\mathbf{c}^{2-} \cdot\left(\mathrm{TBA}^{+}\right)_{2}$ helicates (Figure S13). 

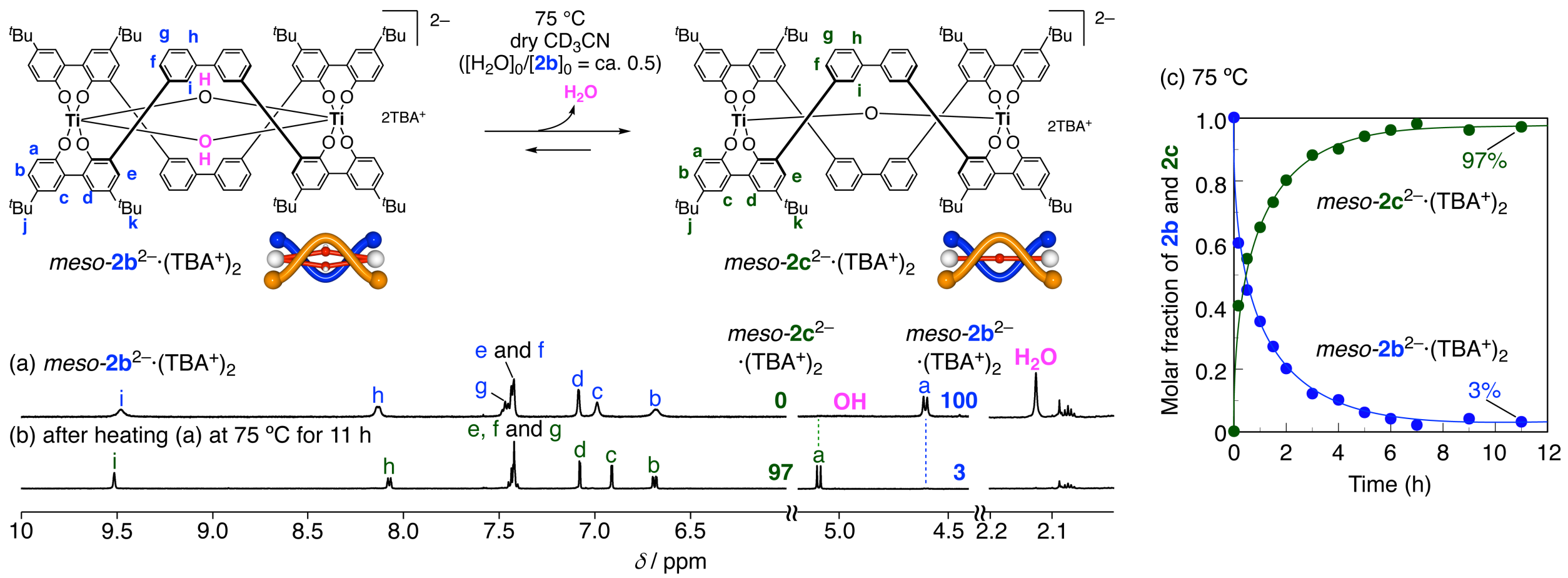

Figure S13. Partial ${ }^{1} \mathrm{H}$ NMR spectra $\left(500 \mathrm{MHz}\right.$, anhydrous $\mathrm{CD}_{3} \mathrm{CN}\left(\left[\mathrm{H}_{2} \mathrm{O}\right]_{0} /\left[\text { meso-2 } \mathbf{b}^{2-} \cdot\left(\mathrm{TBA}^{+}\right)_{2}\right]_{0}=\right.$ ca. 0.5$\left.), 0.50 \mathrm{mM}, 25^{\circ} \mathrm{C}\right)$ of $m e s o-2 \mathbf{b}^{2-} \cdot\left(\mathrm{TBA}^{+}\right)_{2}$ before (a) and after heating at $75{ }^{\circ} \mathrm{C}$ for $11 \mathrm{~h}(\mathrm{~b})$. Plots of the molar fractions of $m e s o-\mathbf{2} \mathbf{b}^{2-} \cdot\left(\mathrm{TBA}^{+}\right)_{2}$ and $m e s o-\mathbf{2} \mathbf{c}^{2-} \cdot\left(\mathrm{TBA}^{+}\right)_{2}$ as a function of time during the transformation at $75^{\circ} \mathrm{C}(\mathrm{c})$, estimated by ${ }^{1} \mathrm{H}$ NMR spectral changes. 


\section{4-3. Mass Measurements of meso-2 $\mathrm{c}^{2-}$ Immediately after Preparation from $m e s o-2 b^{2-}$}

Procedure for Mass Measurements of $m e s o-2 \mathrm{c}^{2-} \cdot\left(\mathrm{Na}^{+} \subset[2.2 .1]\right)_{2}$ Immediately after Preparation from meso- $-\mathbf{b}^{2-} \cdot\left(\mathrm{Na}^{+} \subset[2.2 .1]\right)_{2}$. Transformation from meso-2 $\mathbf{b}^{2-} \cdot\left(\mathrm{Na}^{+} \subset[2.2 .1]\right)_{2}$ to meso$2 \mathbf{c}^{2-} \cdot\left(\mathrm{Na}^{+} \subset[2.2 .1]\right)_{2}$ in a 5-mm NMR tube was performed in a similar way as described in Section 41 (method II) with a slight modification. After reaching an equilibrium at $65{ }^{\circ} \mathrm{C}$ over $20 \mathrm{~h}$ (meso-

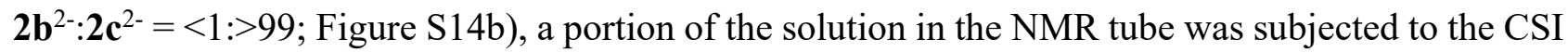
mass spectroscopic analysis immediately after unsealing the NMR tube (within $1 \mathrm{~min}$ ) (Figure S15).

\section{Procedure for Mass Measurements of meso-2 $\mathrm{c}^{2-} \cdot\left(\mathrm{TBA}^{+}\right)_{2}$ Immediately after Preparation from} meso-2 $\mathbf{b}^{2-} \cdot\left(\mathrm{TBA}^{+}\right)_{2}$. Transformation from meso- $\mathbf{b}^{2-} \cdot\left(\mathrm{TBA}^{+}\right)_{2}$ to $m e s o-2 \mathbf{c}^{2-} \cdot\left(\mathrm{TBA}^{+}\right)_{2}$ in a $5-\mathrm{mm} \mathrm{NMR}$ tube was performed as described in Section 4-2. After reaching an equilibrium at $75{ }^{\circ} \mathrm{C}$ over $11 \mathrm{~h}$ (meso-2 $\mathbf{b}^{2-}: \mathbf{2} \mathbf{c}^{2-}=3: 97$; Figure S16b), a portion of the solution in the NMR tube was subjected to the CSI mass spectroscopic analysis immediately after unsealing the NMR tube (within 1 min) (Figure S17).



(a) $m e s o-2 b^{2-} \cdot\left(\mathrm{Na}^{+} \subset[2.2 .1]\right)_{2}$

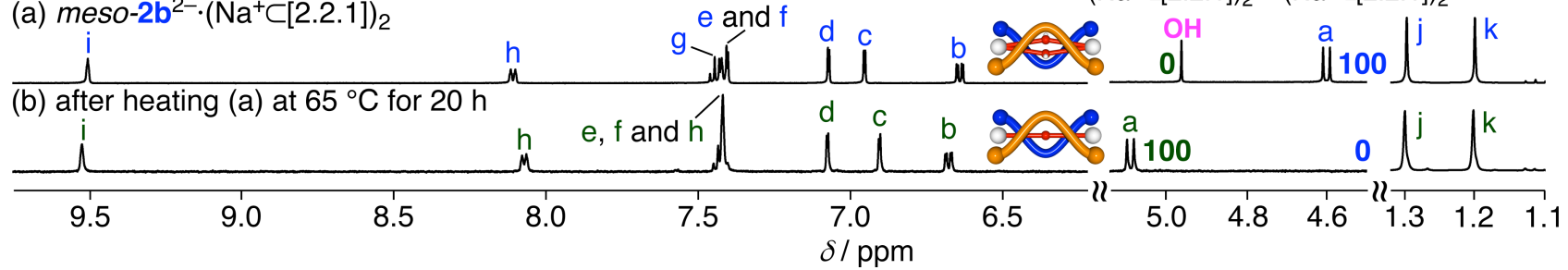

Figure S14. Partial ${ }^{1} \mathrm{H}$ NMR spectra $\left(500 \mathrm{MHz}\right.$, anhydrous $\mathrm{CD}_{3} \mathrm{CN}\left(\left[\mathrm{H}_{2} \mathrm{O}\right]_{0} /\left[\right.\right.$ meso-2 b ${ }^{2-}$ $\left.\cdot\left(\mathrm{Na}^{+} \subset[2.2 .1]\right)_{2}\right]_{0}=$ ca. 0.4), $\left.0.50 \mathrm{mM}, \mathrm{rt}\right)$ of meso- $2 \mathbf{b}^{2-} \cdot\left(\mathrm{Na}^{+}\right)_{2}$ in the presence of 4 equiv of cryptand[2.2.1] before (a) and after heating at $65^{\circ} \mathrm{C}$ for $20 \mathrm{~h}(\mathrm{~b})$. 

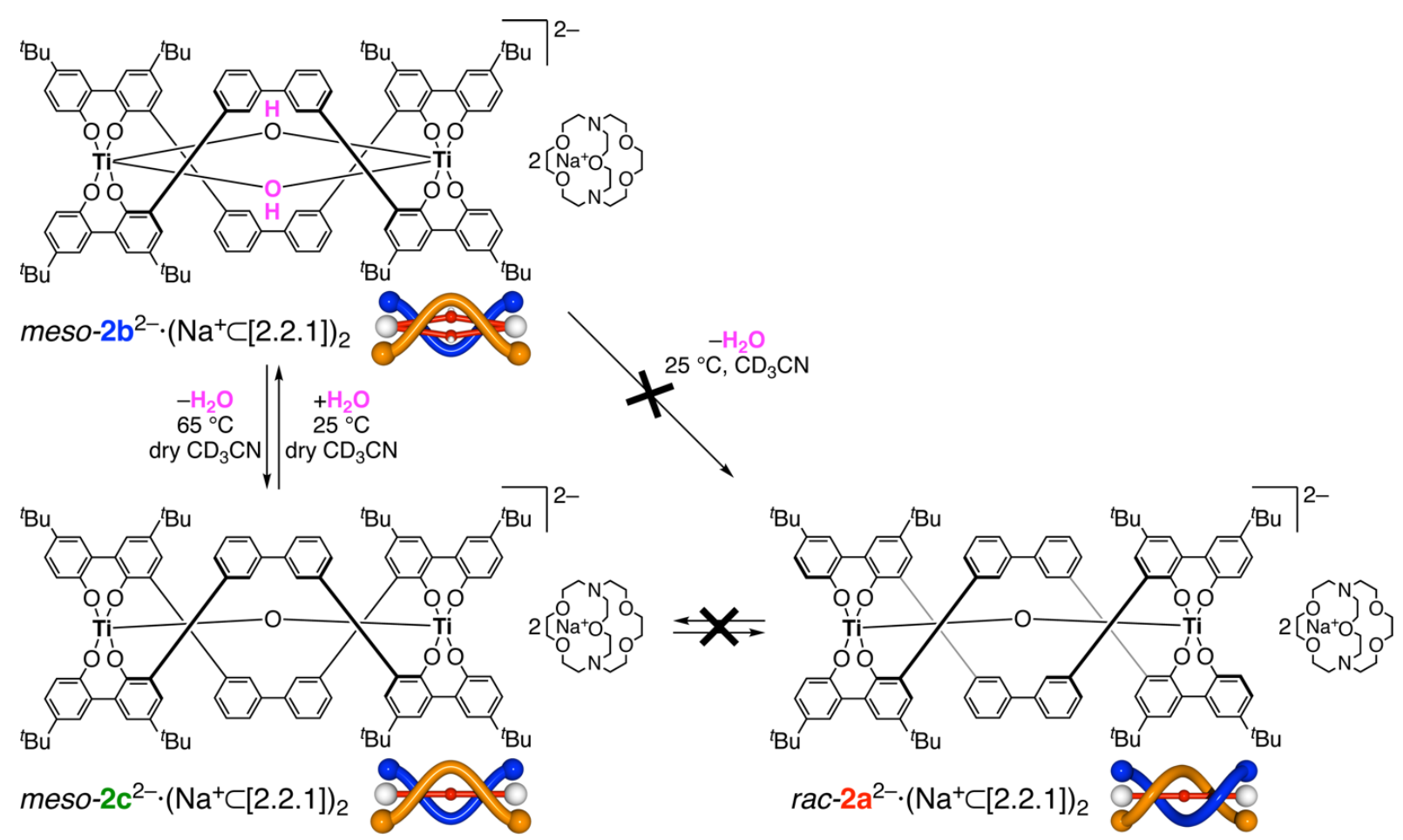

(a) $\left[\right.$ meso-2c ${ }^{2-} \cdot\left(\mathrm{Na}^{+} \subset[2.2 .1]\right)_{2}$

$\left.-\left(\mathrm{Na}^{+} \subset[2.2 .1]\right)_{2}+\mathrm{Na}^{+}\right]^{-}$
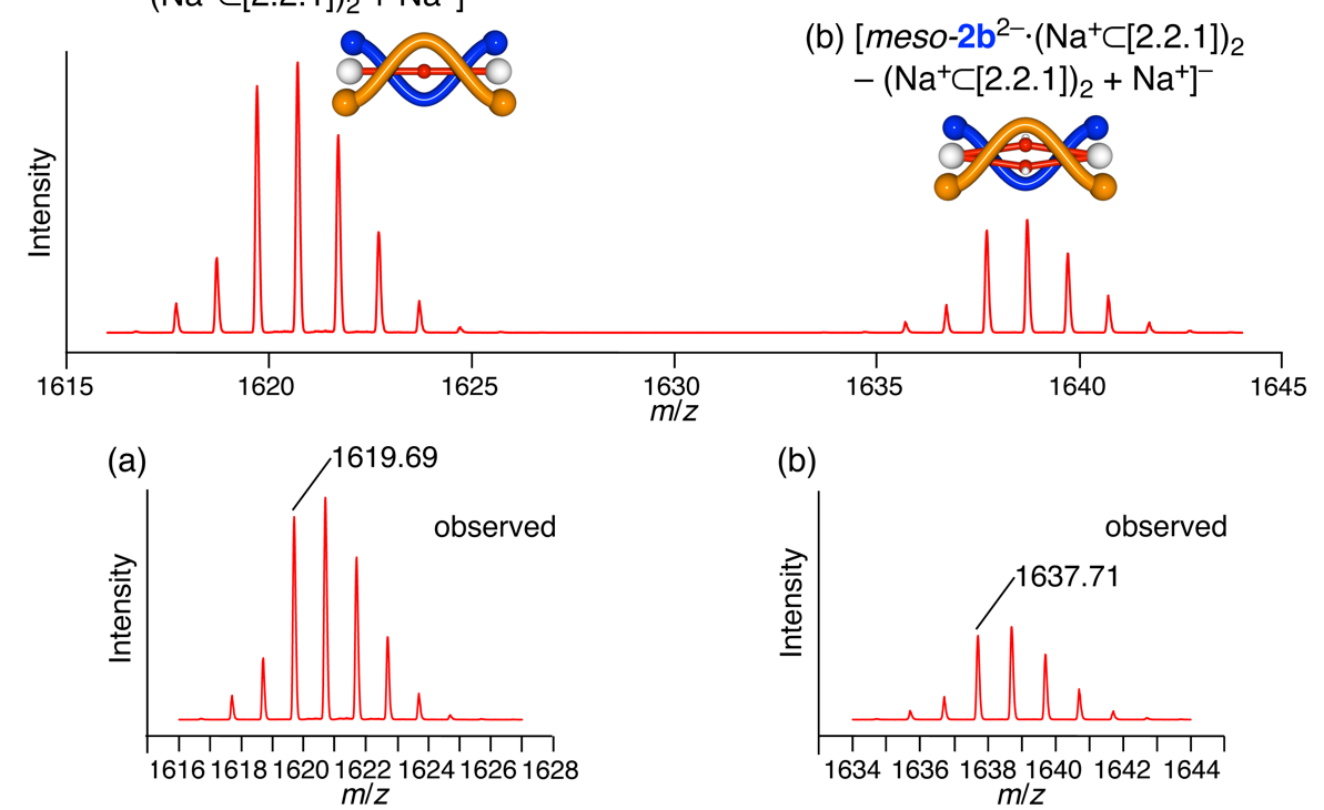

(b)


Figure S15. Negative mode CSI mass spectra (anhydrous $\mathrm{CD}_{3} \mathrm{CN}, 0.50 \mathrm{mM},-20{ }^{\circ} \mathrm{C}$ ) of $m e s o-2 \mathbf{b}^{2-}$ $\cdot\left(\mathrm{Na}^{+}\right)_{2}$ in the presence of 4 equiv of cryptand[2.2.1] after heating at $65^{\circ} \mathrm{C}$ for $20 \mathrm{~h}$. 

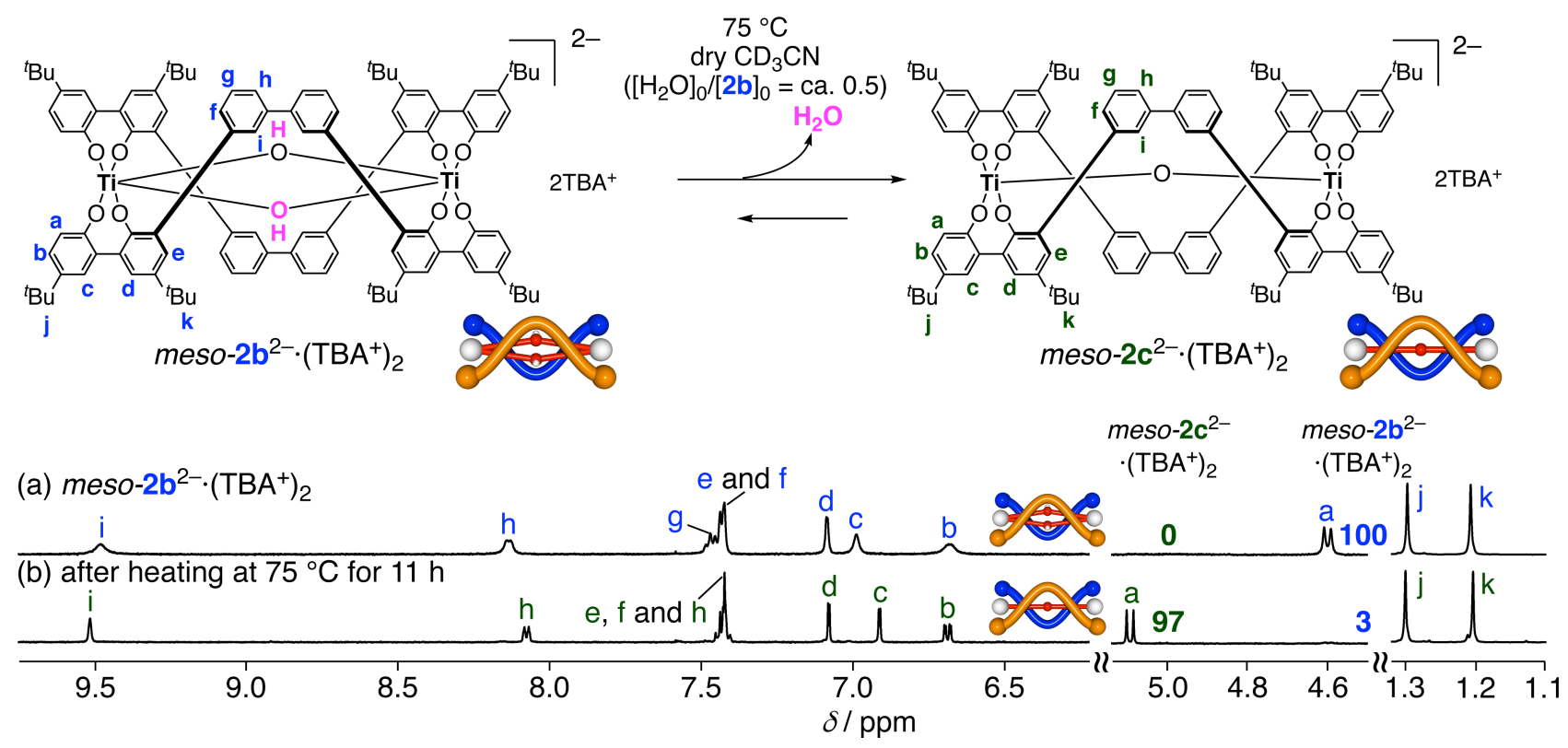

Figure S16. Partial ${ }^{1} \mathrm{H}$ NMR spectra $\left(500 \mathrm{MHz}\right.$, anhydrous $\mathrm{CD}_{3} \mathrm{CN}\left(\left[\mathrm{H}_{2} \mathrm{O}\right]_{0} /\left[\right.\right.$ meso-2 $\mathbf{b}^{2-} \cdot\left(\mathrm{TBA}^{+}\right]_{0}=$ ca. 0.5 ), $0.50 \mathrm{mM}, 25^{\circ} \mathrm{C}$ ) before (a) and after heating at $75^{\circ} \mathrm{C}$ for $11 \mathrm{~h}(\mathrm{~b})$. 


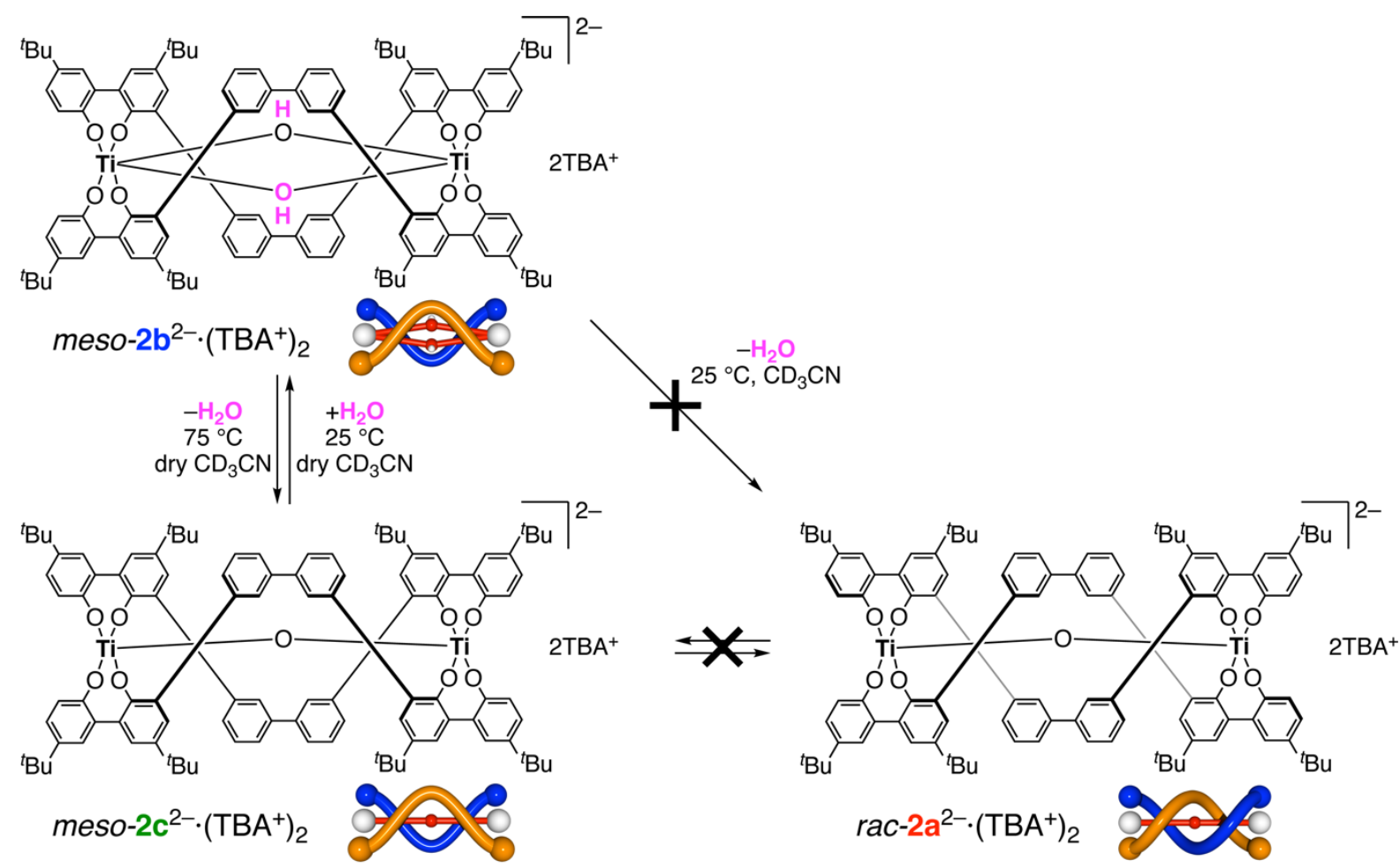

(a) $\left[\text { meso-2c }{ }^{2-} \cdot\left(\mathrm{TBA}^{+}\right)_{2}-\left(\mathrm{TBA}^{+}\right)_{2}\right]^{-}$

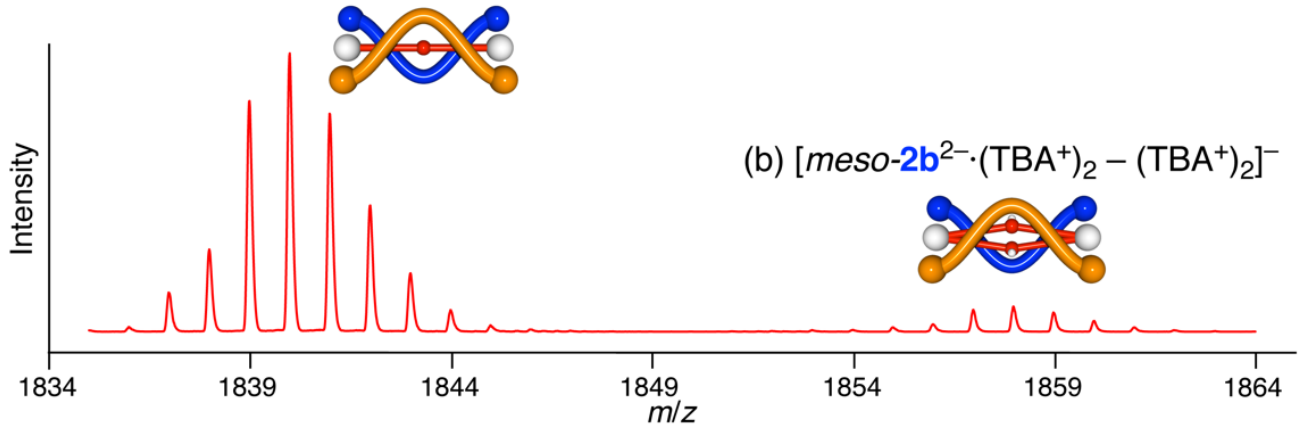

(a) $\quad 1838.98$

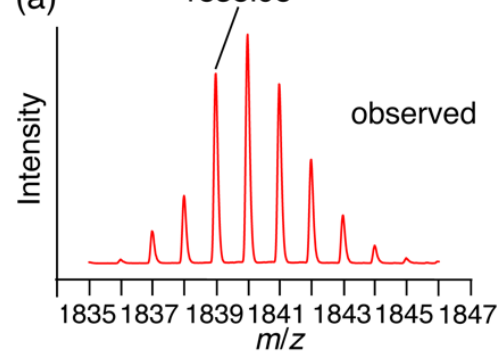

(b)
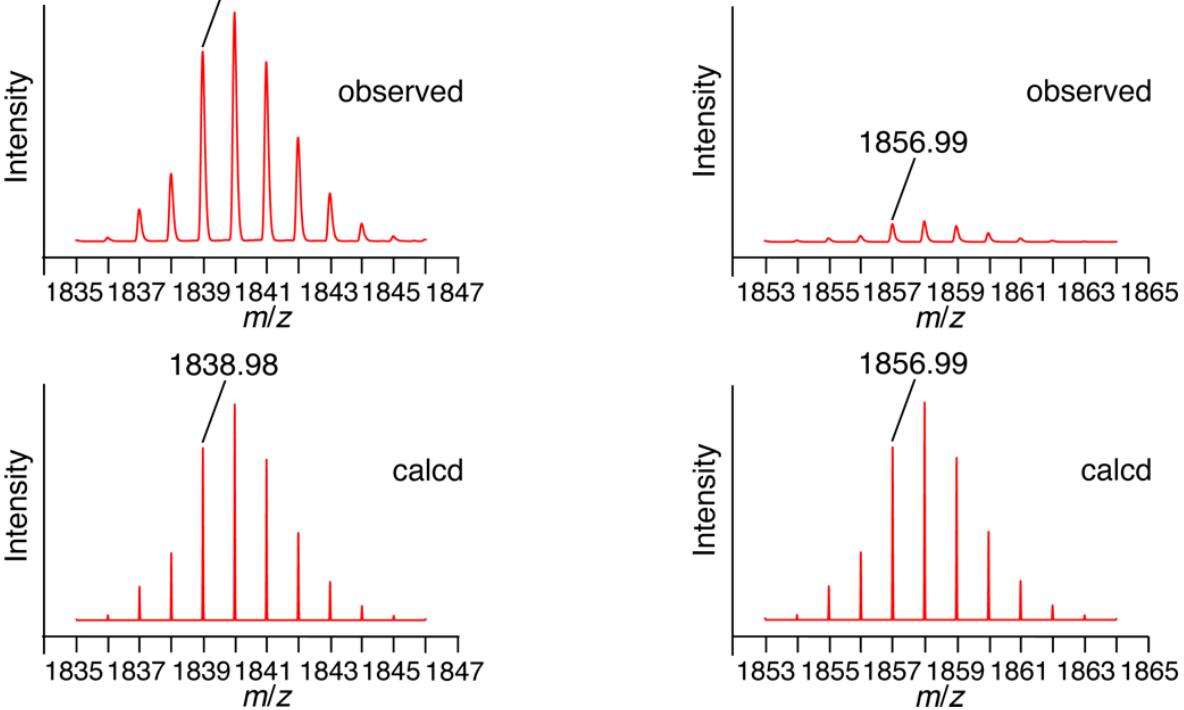

Figure S17. Negative mode CSI mass spectra (anhydrous $\mathrm{CD}_{3} \mathrm{CN}, 0.50 \mathrm{mM},-20{ }^{\circ} \mathrm{C}$ ) of $m e s o-2 \mathbf{b}^{2-}$ $\cdot\left(\mathrm{TBA}^{+}\right)_{2}$ after heating at $75^{\circ} \mathrm{C}$ for $11 \mathrm{~h}$. 


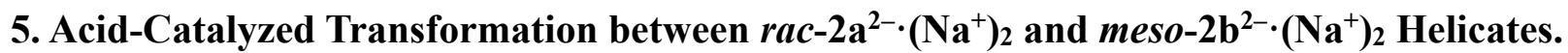

Procedure for meso- $2 \mathrm{~b}^{2-} \cdot\left(\mathrm{Na}^{+}\right)_{2}$ to $\mathrm{rac}-2 \mathrm{a}^{2-} \cdot\left(\mathrm{Na}^{+}\right)_{2}$ Transformation in the Presence of $p$ Toluenesulfonic Acid in Acetonitrile Containing a Small Amount of Water. A mixture of meso$\mathbf{2 b}^{2-} \cdot\left(\mathrm{Na}^{+}\right)_{2}(0.50 \mathrm{mM}, 0.50 \mu \mathrm{mol})$ and $p$-toluenesulfonic acid $(p-\mathrm{TsOH}) \quad\left([p-\mathrm{TsOH}]_{0} /[\right.$ meso$\left.\left.\mathbf{2 b}^{2-} \cdot\left(\mathrm{Na}^{+}\right)_{2}\right]_{0}=0.10\right)$ in dry $\mathrm{CD}_{3} \mathrm{CN}(1.0 \mathrm{~mL})$ containing a small amount of $\mathrm{H}_{2} \mathrm{O}\left(\left[\mathrm{H}_{2} \mathrm{O}\right]_{0} /[\right.$ meso$\left.\mathbf{2 b}^{2-} \cdot\left(\mathrm{Na}^{+}\right)_{2}\right]_{0}=$ ca. 9) was prepared in a 5-mm NMR tube under argon (Figure 5Aa). The NMR tube was sealed at $-78{ }^{\circ} \mathrm{C}$ under vacuum and then placed in an oil bath preheated to $35^{\circ} \mathrm{C}$, and the meso$\mathbf{2 b}^{2-} \cdot\left(\mathrm{Na}^{+}\right)_{2}$ to $\mathrm{rac}-\mathbf{2} \mathbf{a}^{2-} \cdot\left(\mathrm{Na}^{+}\right)_{2}$ transformation progress was monitored by ${ }^{1} \mathrm{H}$ NMR spectroscopy at an appropriate time interval (Figure 5Ca). The meso-2 $\mathbf{b}^{2-} \cdot\left(\mathrm{Na}^{+}\right)_{2}$ helicate finally reached an

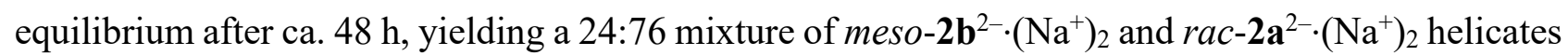
(Figure $5 \mathrm{Ab}, \mathrm{Ca}$ ).

Procedure for $r a c-2 a^{2-} \cdot\left(\mathrm{Na}^{+}\right)_{2}$ to meso- $2 \mathrm{~b}^{2-} \cdot\left(\mathrm{Na}^{+}\right)_{2}$ Transformation in the Presence of $p$ Toluenesulfonic Acid in Acetonitrile Containing a Large Amount of Water. A mixture of rac$\mathbf{2 a}^{2-} \cdot\left(\mathrm{Na}^{+}\right)_{2}(0.50 \mathrm{mM}, 0.37 \mu \mathrm{mol})$ and $p-\mathrm{TsOH}\left([p-\mathrm{TsOH}]_{0} /\left[\mathrm{rac}-\mathbf{2 a}^{2-} \cdot\left(\mathrm{Na}^{+}\right)_{2}\right]_{0}=0.10\right)$ in dry $\mathrm{CD}_{3} \mathrm{CN}$ $(740 \mu \mathrm{L})$ containing a large amount of $\mathrm{H}_{2} \mathrm{O}\left(\left[\mathrm{H}_{2} \mathrm{O}\right]_{0} /\left[\mathrm{rac}-\mathbf{2 a}^{2-} \cdot\left(\mathrm{Na}^{+}\right)_{2}\right]_{0}>\right.$ ca. 1000) was prepared in a 5-mm NMR tube under argon (Figure 5Ba). The NMR tube was sealed at $-78^{\circ} \mathrm{C}$ under vacuum and then placed in an oil bath preheated to $35{ }^{\circ} \mathrm{C}$, and the $\mathrm{rac}-\mathbf{2} \mathbf{a}^{2-} \cdot\left(\mathrm{Na}^{+}\right)_{2}$ to meso-2 $\mathbf{b}^{2-} \cdot\left(\mathrm{Na}^{+}\right)_{2}$ transformation progress was monitored by ${ }^{1} \mathrm{H}$ NMR spectroscopy at an appropriate time interval (Figure 5Cb). The $\mathrm{rac}-\mathbf{2 a}^{2-} \cdot\left(\mathrm{Na}^{+}\right)_{2}$ helicate finally reached an equilibrium after ca. $5 \mathrm{~h}$, yielding a 2:98 mixture of $\mathrm{rac}-\mathbf{2 a}^{2-} \cdot\left(\mathrm{Na}^{+}\right)_{2}$ and meso-2 $\mathbf{b}^{2-} \cdot\left(\mathrm{Na}^{+}\right)_{2}$ helicates (Figure 5Bb, Cb). 


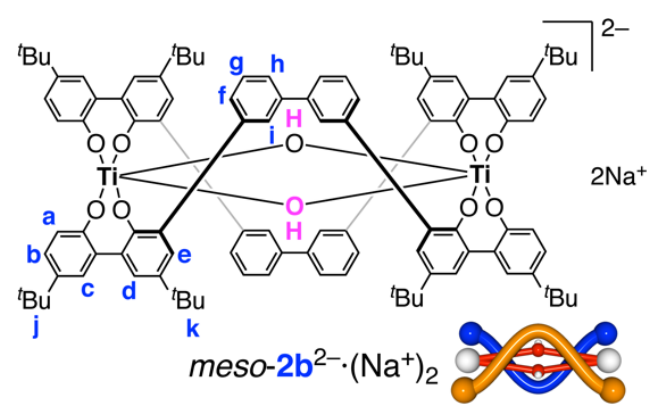

A

(a) $m e s o-2 b^{2-} \cdot\left(\mathrm{Na}^{+}\right)_{2}$

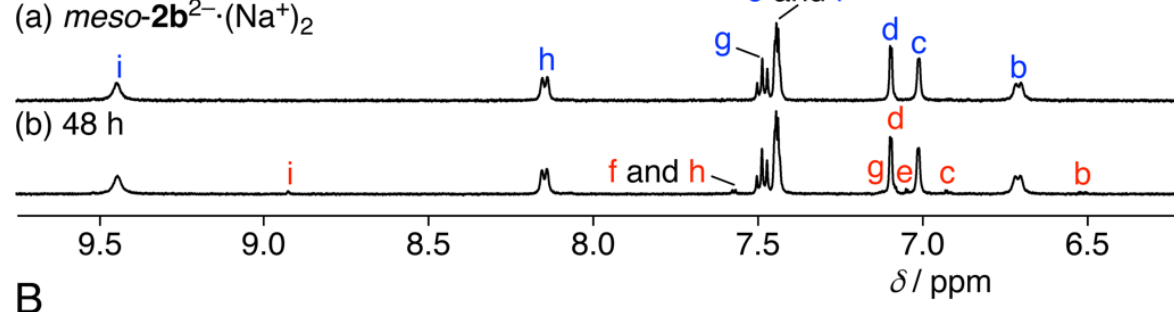

B

(a) $r a c-2 a^{2-} \cdot\left(\mathrm{Na}^{+}\right)_{2}$
$A$

$35^{\circ} \mathrm{C}, \mathrm{CD}_{3} \mathrm{CN}$

$\left(\left[\mathrm{H}_{2} \mathrm{O}\right]_{0} /[2 \mathrm{~b}]_{0}=\right.$ ca. 10$)$

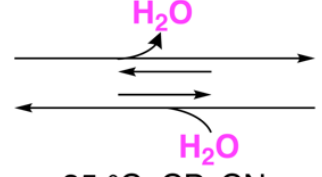

$35^{\circ} \mathrm{C}, \mathrm{CD}_{3} \mathrm{CN}$ $\left(\left[\mathrm{H}_{2} \mathrm{O}\right]_{0} /[2 \mathrm{a}]_{0}>\right.$ ca. 1000$)$

$B$

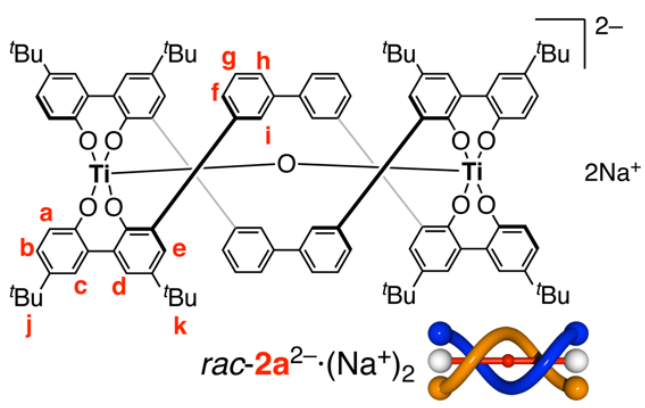

rac-2a $\mathrm{a}^{2-} \quad$ meso-2 $\mathrm{b}^{2-}$ $\cdot\left(\mathrm{Na}^{+}\right)_{2} \quad \cdot\left(\mathrm{Na}^{+}\right)_{2}$

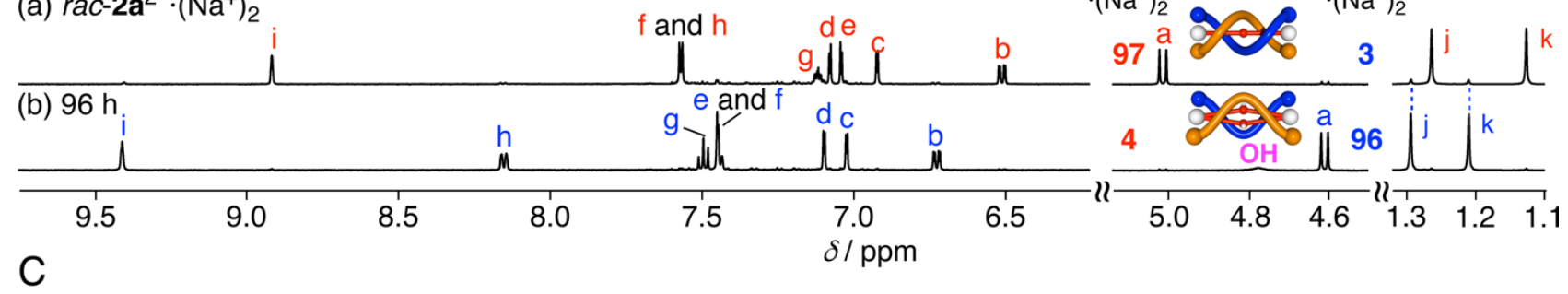

(a) in the absence of $p$ - $\mathrm{TsOH}$

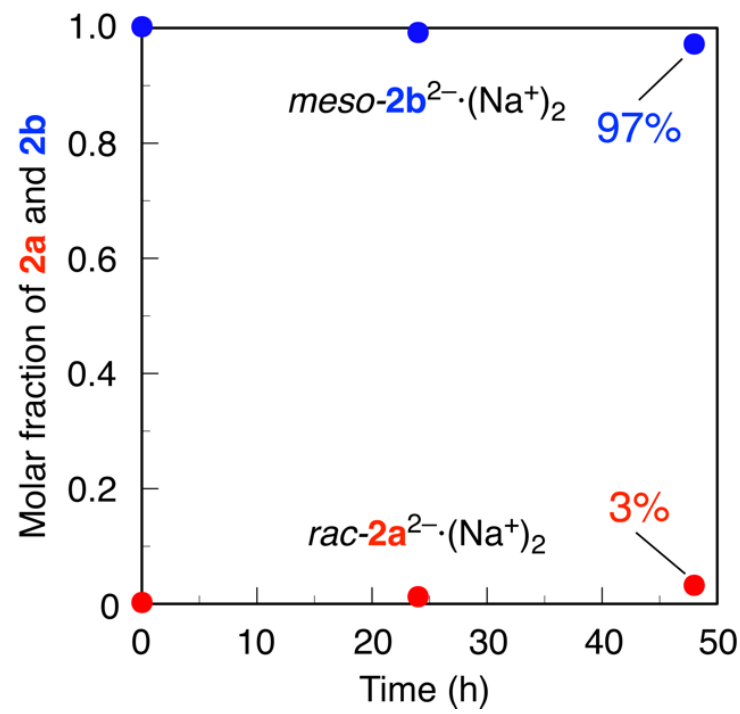

(b) in the absence of $p-\mathrm{TsOH}$



Figure S18. (A) ${ }^{1} \mathrm{H}$ NMR spectra of meso-2 $\mathbf{b}^{2-} \cdot\left(\mathrm{Na}^{+}\right)_{2}\left(500 \mathrm{MHz}, \mathrm{CD}_{3} \mathrm{CN}\right.$ containing $\mathrm{H}_{2} \mathrm{O}$ $\left(\left[\mathrm{H}_{2} \mathrm{O}\right]_{0} /\left[\text { meso-2 } \mathbf{b}^{2-} \cdot\left(\mathrm{Na}^{+}\right)_{2}\right]_{0}=\right.$ ca. 10$\left.), 0.50 \mathrm{mM}\right)$ in the absence of $p$-TsOH measured at $35^{\circ} \mathrm{C}$ before (a) and after heating at $35^{\circ} \mathrm{C}$ for $48 \mathrm{~h}$ (b). (B) ${ }^{1} \mathrm{H} \mathrm{NMR}$ spectra of $\mathrm{rac}-\mathbf{2 a}^{2-} \cdot\left(\mathrm{Na}^{+}\right)_{2}\left(500 \mathrm{MHz}, \mathrm{CD}_{3} \mathrm{CN}\right.$ containing $\mathrm{H}_{2} \mathrm{O}\left(\left[\mathrm{H}_{2} \mathrm{O}\right]_{0} /\left[\mathrm{rac}-\mathbf{2 a}^{2-} \cdot\left(\mathrm{Na}^{+}\right)_{2}\right]_{0}>\right.$ ca. 1000$\left.), 0.50 \mathrm{mM}\right)$ in the absence of $p$-TsOH before (a) and after heating at $35^{\circ} \mathrm{C}$ for $96 \mathrm{~h} \mathrm{(b),} \mathrm{measured} \mathrm{at} 35^{\circ} \mathrm{C}$. (C) (a) Plots of the molar fractions of meso- $\mathbf{2} \mathbf{b}^{2-} \cdot\left(\mathrm{Na}^{+}\right)_{2}$ and $r a c-2 \mathbf{a}^{2-} \cdot\left(\mathrm{Na}^{+}\right)_{2}$ as a function of time during the meso-2 $\mathbf{b}^{2-}$-to-rac-2 $\mathbf{a}^{2-}$ (a) and rac-2-2a ${ }^{2-}$-to-meso- $\mathbf{2} \mathbf{b}^{2-}$ transformations (b), estimated by ${ }^{1} \mathrm{H}$ NMR spectral changes. The solid lines are drawn to guide the eyes. 


\section{X-ray Crystallographic Data}

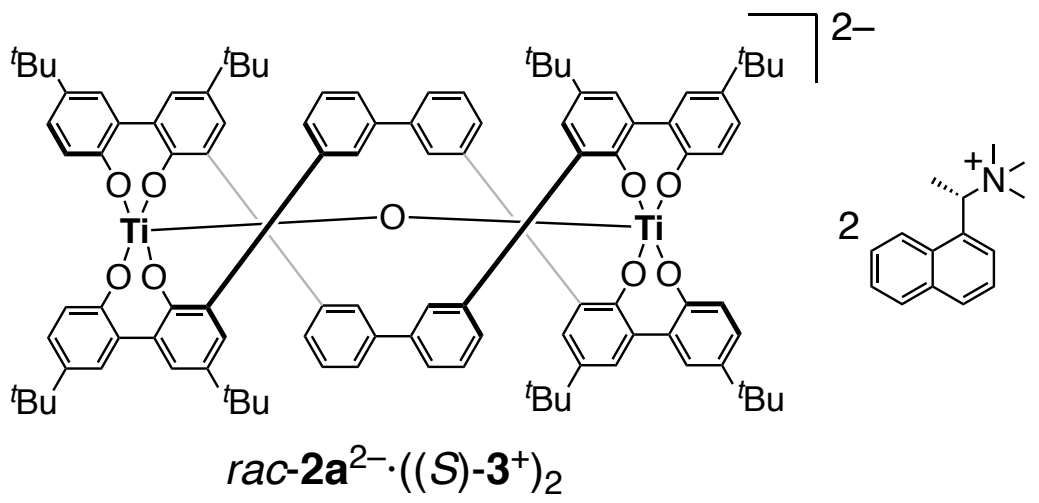

\section{Crystallographic Data of $r a c-2 a^{2-} \cdot\left((S)-3^{+}\right)_{2}$}

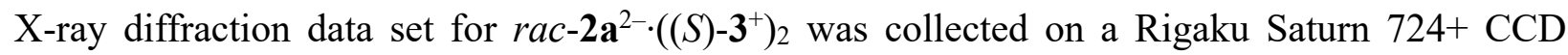
diffractometer with Mo K $\alpha$ radiation $(\lambda=0.71075 \AA)$ at $163(2) \mathrm{K}$. Single crystals of $\mathrm{rac}^{-2 \mathbf{a}^{2-}} \cdot((S)$ $\left.\mathbf{3}^{+}\right)_{2}\left[\mathrm{C}_{156} \mathrm{H}_{181} \mathrm{~N}_{13} \mathrm{O}_{9} \mathrm{Ti}_{2}, \mathrm{MW}=2,477.94\right]$ suitable for $\mathrm{X}$-ray analysis were grown by slow evaporation of a solution of $\mathrm{rac}-\mathbf{2 a}^{2-} \cdot\left(\mathrm{Na}^{+}\right)_{2}$ with $(S)-\mathbf{3}^{+} \cdot \mathrm{I}^{-}\left(100\right.$ equiv) in $\mathrm{CH}_{3} \mathrm{CN}$, and a single orange crystal with dimensions $0.22 \times 0.09 \times 0.07 \mathrm{~mm}^{3}$ was selected for intensity measurements. The unit cell was monoclinic with the space group $C 2$. Lattice constants with $Z=4, \rho_{\text {calcd }}=1.161 \mathrm{~g} \mathrm{~cm}^{-3}, \mu(\mathrm{MoK} \alpha)=$ $0.174 \mathrm{~mm}^{-1}, F(000)=5,296,2 \theta_{\max }=54.98^{\circ}$ were $a=24.448(5) \AA, b=20.426(4), c=28.398(6) \AA$, and $V=14,178(5) \AA^{3}$. A total of 53,065 reflections was collected, of which 22,172 reflections were independent $\left(R_{\text {int }}=0.0307\right)$. The structure was refined to final $R_{1}=0.0579$ for 20,270 data $[I>2 \sigma(I)]$ with 1,631 parameters and $w R_{2}=0.1527$ for all data, $G O F=1.050$, and residual electron density $\max / \min =0.394 /-0.410$ e $\AA^{-3}$. The ORTEP drawing is shown in Figure S19, and crystal data and structure refinement are listed in Table S1.

Data collection and processing were conducted using the Rigaku CrystalClear software package. ${ }^{\text {S2 }}$ The structure was solved by direct methods using Sir $2004^{\mathrm{S} 3}$ and refined by full-matrix least squares methods on $F^{2}$ with SHELXL-97 program ${ }^{\mathrm{S} 4, \mathrm{~S} 5}$ using Yadokari-XG 2009. ${ }^{\mathrm{S} 6}$ All non-hydrogen atoms were refined anisotropically. All hydrogen atoms were calculated geometrically and refined using the riding model. Crystallographic data have been deposited at the CCDC (12 Union Road, Cambridge CB2 1EZ, UK) and copies can be obtained on request, free of charge, by quoting the publication citation and the deposition number 1988440. 


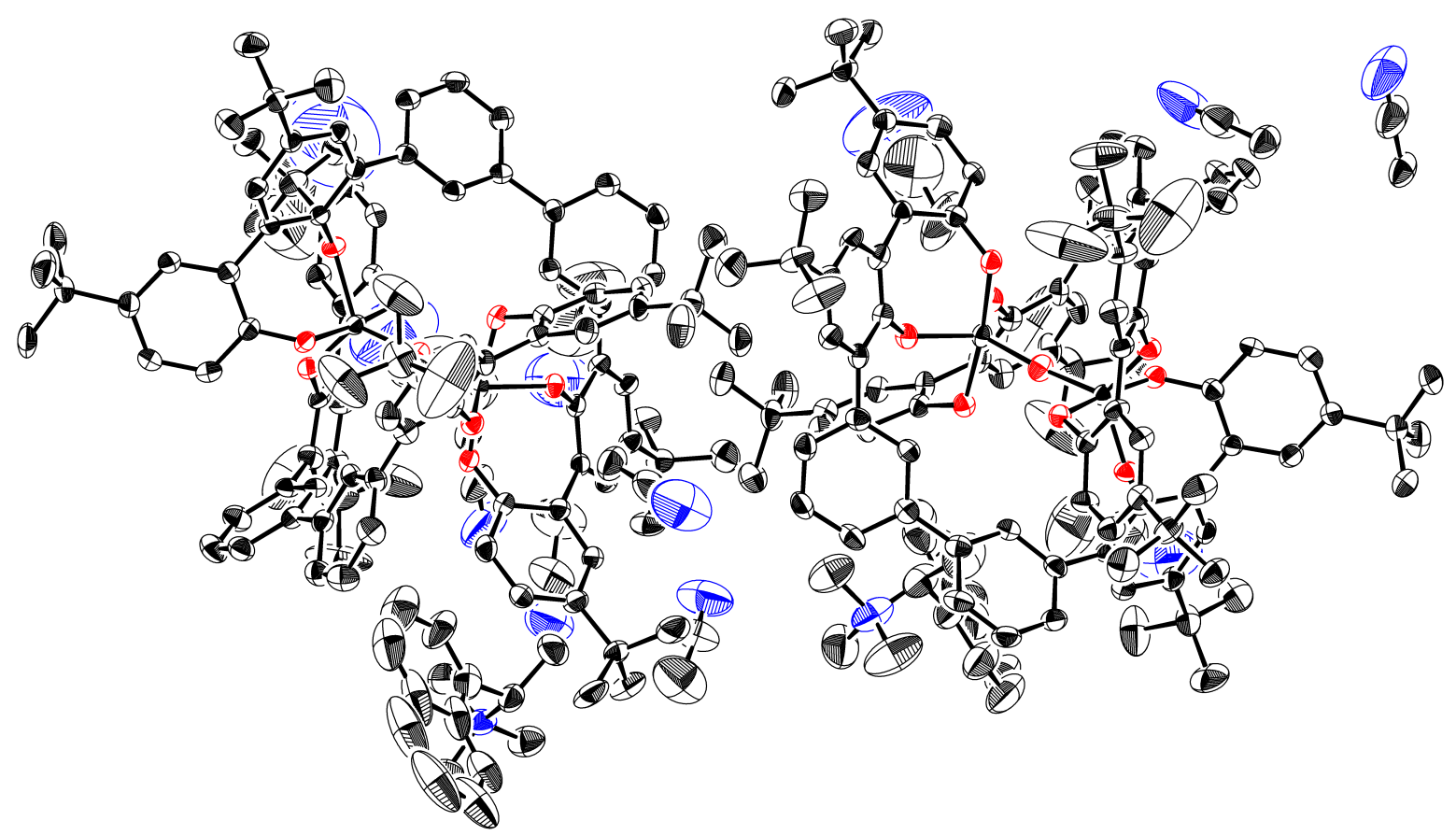

Figure S19. ORTEP drawing of the crystal structure of $\mathrm{rac}_{-} \mathbf{2} \mathbf{a}^{2-} \cdot\left((S)-\mathbf{3}^{+}\right)_{2}$ with thermal ellipsoids at $50 \%$ probability. Hydrogen atoms are omitted for clarity.

Table S1. Crystal data and structure refinement for $r a c-2 \mathbf{a}^{2-} \cdot\left((S)-\mathbf{3}^{+}\right)_{2}$

Empirical formula

Formula weight

Temperature

Wavelength

Crystal system

Space group

Unit cell dimensions

Volume

Z

Density (calculated)

Absorption coefficient

$\mathrm{F}(000)$

Crystal size

Theta range for data collection

Index ranges

Reflections collected

Independent reflections

Completeness to theta $=26.00^{\circ}$

Absorption correction

Max. and min. transmission

Refinement method

Data / restraints / parameters

Goodness-of-fit on $\mathrm{F}^{2}$

Final R indices [I $>2 \operatorname{sigma}(\mathrm{I})]$

$\mathrm{R}$ indices (all data)

Largest diff. peak and hole

CCDC reference number
$\mathrm{C}_{156} \mathrm{H}_{181} \mathrm{~N}_{13} \mathrm{O}_{9} \mathrm{Ti}_{2}$

$2,477.94$

$163(2) \mathrm{K}$

$0.71075 \AA$

Monoclinic

$C 2$

$\mathrm{a}=24.448(5) \AA$

$\mathrm{b}=20.426(4) \AA$

$\mathrm{c}=28.398(6) \AA$

$14,178(5) \AA^{3}$

4

$1.161 \mathrm{~g} \mathrm{~cm}^{-3}$

$0.174 \mathrm{~mm}^{-1}$

5,296

$0.22 \times 0.09 \times 0.07 \mathrm{~mm}^{3}$

3.03 to $26.00^{\circ}$.

$-29<=\mathrm{h}<=30,-22<=\mathrm{k}<=25,-35<=1<=35$

53,065

$22,172\left[R_{\text {int }}=0.0307\right]$

$99.5 \%$

Semi-empirical from equivalents

1.0000 and 0.9017

Full-matrix least-squares on $\mathrm{F}^{2}$

$22,172 / 120 / 1,631$

1.050

$R_{1}=0.0579, w R_{2}=0.1474$

$R_{1}=0.0632, w R_{2}=0.1527$

0.394 and $-0.410 \mathrm{e}^{-3}$

1988440 $\alpha=90.00^{\circ}$.

$\beta=91.170(4)^{\circ}$.

$\gamma=90.00^{\circ}$. 


\section{X-ray Crystallographic Data}

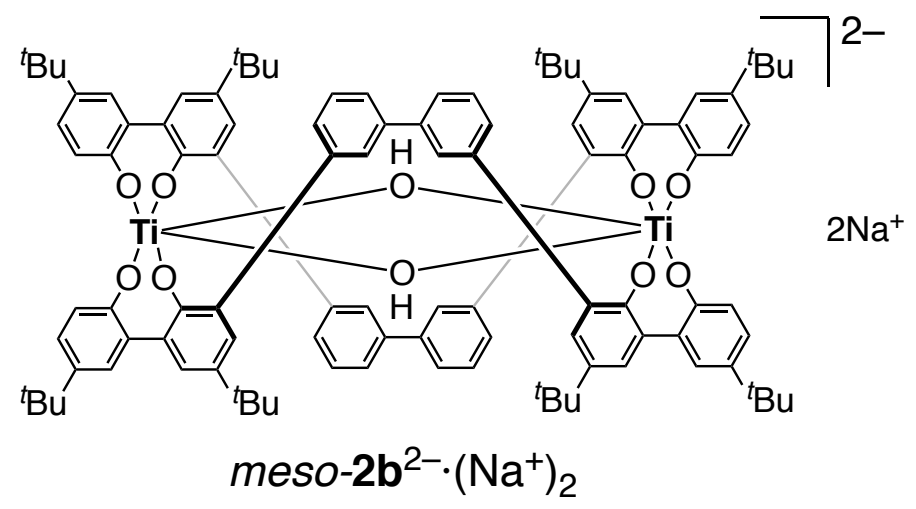

\section{Crystallographic Data of meso- $2 \mathrm{~b}^{2-\cdot} \cdot\left(\mathrm{Na}^{+}\right)_{2}$}

X-ray diffraction data set for meso-2 $\mathbf{b}^{2-} \cdot\left(\mathrm{Na}^{+}\right)_{2}$ was collected on a Rigaku Saturn $724+$ CCD diffractometer with Mo K $\alpha$ radiation $(\lambda=0.71075 \AA)$ at $163.1500 \mathrm{~K}$. Single crystals of meso$\mathbf{2 b}^{2-} \cdot\left(\mathrm{Na}^{+}\right)_{2}\left[\mathrm{C}_{126} \mathrm{H}_{130} \mathrm{Cl}_{4} \mathrm{~N}_{4} \mathrm{Na}_{2} \mathrm{O}_{12} \mathrm{Ti}_{2}, \mathrm{MW}=2,175.92\right]$ suitable for $\mathrm{X}$-ray analysis were obtained by the slow diffusion of $n$-hexane into a $\mathrm{CH}_{2} \mathrm{Cl}_{2}$ solution of meso-2 $\mathbf{b}^{2-} \cdot\left(\mathrm{Na}^{+}\right)_{2}$, and a single orange crystal with dimensions $0.24 \times 0.17 \times 0.08 \mathrm{~mm}^{3}$ was selected for intensity measurements. The unit cell was monoclinic with the space group $P 2_{1} / \mathrm{n}$. Lattice constants with $Z=4, \rho_{\text {calcd }}=1.181 \mathrm{~g} \mathrm{~cm}^{-3}, \mu(\mathrm{MoK} \alpha)$ $=0.283 \mathrm{~mm}^{-1}, F(000)=4,576,2 \theta_{\max }=54.9864^{\circ}$ were $a=15.4084(12) \AA, b=24.6465(19), c=$ 32.428(3) $\AA$, and $V=12236.8(17) \AA^{3}$. A total of 90,054 reflections was collected, of which 23,931 reflections were independent $\left(R_{\text {int }}=0.0283\right)$. The structure was refined to final $R_{1}=0.0821$ for 21,393 data $[I>2 \sigma(I)]$ with 1,472 parameters and $w R_{2}=0.2467$ for all data, $G O F=1.058$, and residual electron density $\max / \min =1.211 /-1.546 \mathrm{e} \AA^{-3}$. The ORTEP drawing is shown in Figure S20, and crystal data and structure refinement are listed in Table S2.

Data collection and processing were conducted using the Rigaku CrystalClear software package. ${ }^{\text {S2 }}$ The structure was solved by direct methods using Sir $2004^{\mathrm{S} 3}$ and refined by full-matrix least squares methods on $F^{2}$ with SHELXL-97 program ${ }^{\text {S4,S5 }}$ using Yadokari-XG 2009. ${ }^{\text {S6 }}$ All non-hydrogen atoms were refined anisotropically. All hydrogen atoms were calculated geometrically and refined using the riding model. Crystallographic data have been deposited at the CCDC (12 Union Road, Cambridge CB2 1EZ, UK) and copies can be obtained on request, free of charge, by quoting the publication citation and the deposition number 1988441. 

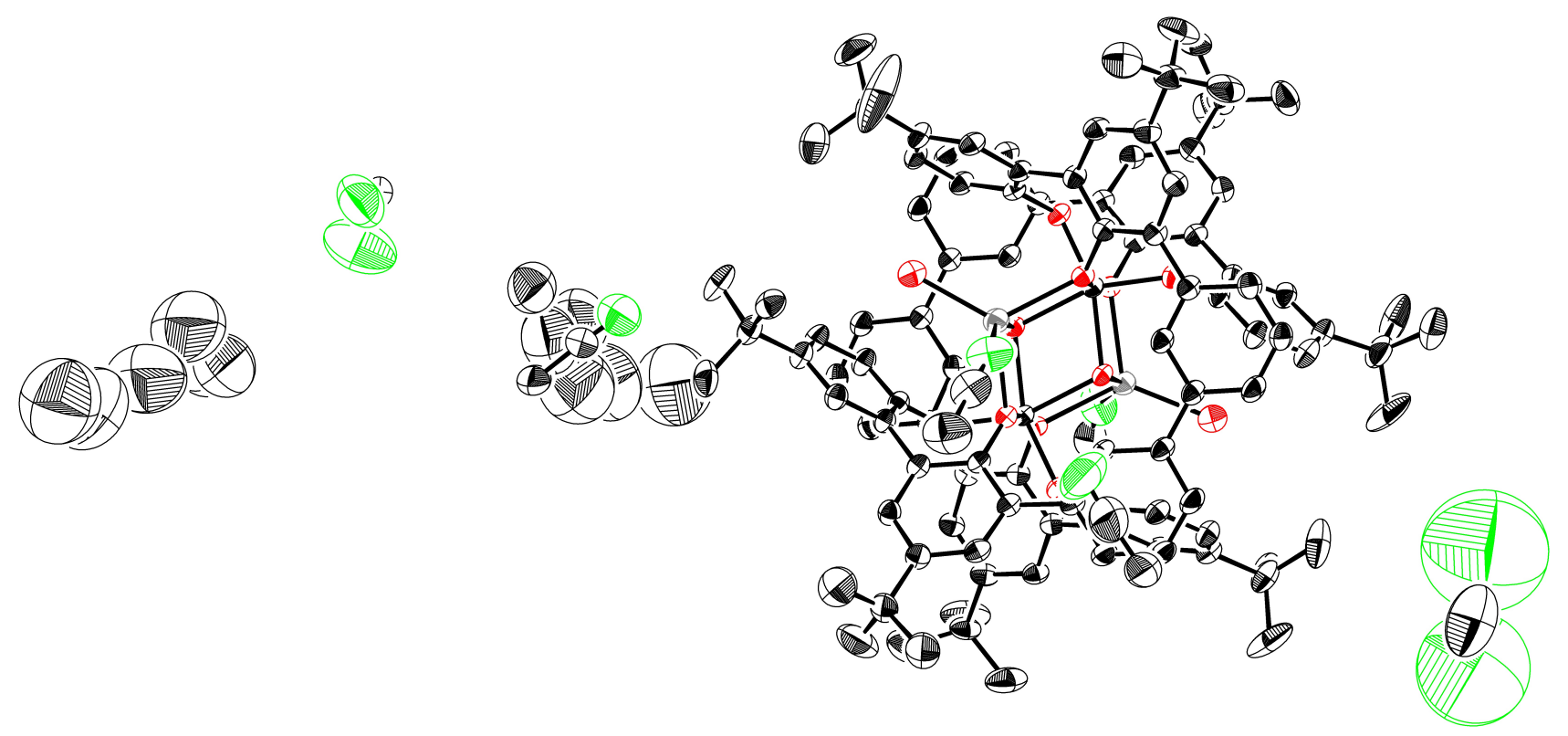

Figure S20. ORTEP drawing of the crystal structure of $m e s o-\mathbf{2 b}^{2-} \cdot\left(\mathrm{Na}^{+}\right)_{2}$ with thermal ellipsoids at $50 \%$ probability. Hydrogen atoms are omitted for clarity.

Table S2. Crystal data and structure refinement for $m e s o-\mathbf{2 b}^{2-} \cdot\left(\mathrm{Na}^{+}\right)_{2}$

Empirical formula

Formula weight

Temperature

Wavelength

Crystal system

Space group

Unit cell dimensions

Volume

Z

Density (calculated)

Absorption coefficient

$\mathrm{F}(000)$

Crystal size

Theta range for data collection

Index ranges

Reflections collected

Independent reflections

Completeness to theta $=26.00^{\circ}$

Absorption correction

Max. and min. transmission

Refinement method

Data / restraints / parameters

Goodness-of-fit on $\mathrm{F}^{2}$

Final R indices [I $>2 \operatorname{sigma}(\mathrm{I})]$

$\mathrm{R}$ indices (all data)

Largest diff. peak and hole

CCDC reference number
$\mathrm{C}_{126} \mathrm{H}_{130} \mathrm{Cl}_{4} \mathrm{~N}_{4} \mathrm{Na}_{2} \mathrm{O}_{12} \mathrm{Ti}_{2}$

$2,175.92$

$163.1500 \mathrm{~K}$

$0.71075 \AA$

monoclinic

$P 21 / \mathrm{n}$

$\mathrm{a}=15.4084(12) \AA$

$\alpha=90.00^{\circ}$.

$\beta=96.4640(10)^{\circ}$.

$\mathrm{b}=24.6465(19) \AA$

$\mathrm{c}=32.428(3) \AA$

$12,236.8(17) \AA^{3}$

$\gamma=90.00^{\circ}$.

4

$1.181 \mathrm{~g} \mathrm{~cm}^{-3}$

$0.283 \mathrm{~mm}^{-1}$

4,576

$0.24 \times 0.17 \times 0.08 \mathrm{~mm}^{3}$

3.02 to $26.00^{\circ}$.

$-19<=\mathrm{h}<=18,-26<=\mathrm{k}<=30,-40<=1<=40$

90,054

$23,931\left[R_{\text {int }}=0.0283\right]$

$99.6 \%$

Semi-empirical from equivalents

1.0000 and 0.8849

Full-matrix least-squares on $\mathrm{F}^{2}$

$23,931 / 163 / 1,472$

1.058

$R_{1}=0.0821, w R_{2}=0.2383$

$R_{1}=0.0888, w R_{2}=0.2467$

1.211 and $-1.546 \mathrm{e}^{-3}$

1988441 
Table S3. Selected Bond Distances $\left(d_{\mathrm{Ti}-\mathrm{Ti}}\right)$ between Two Titanium Atoms, Bond Angles, and Dihedral Angles of the Crystal Structures of rac-2a ${ }^{2-}$ and meso-2 $\mathrm{b}^{2-}$
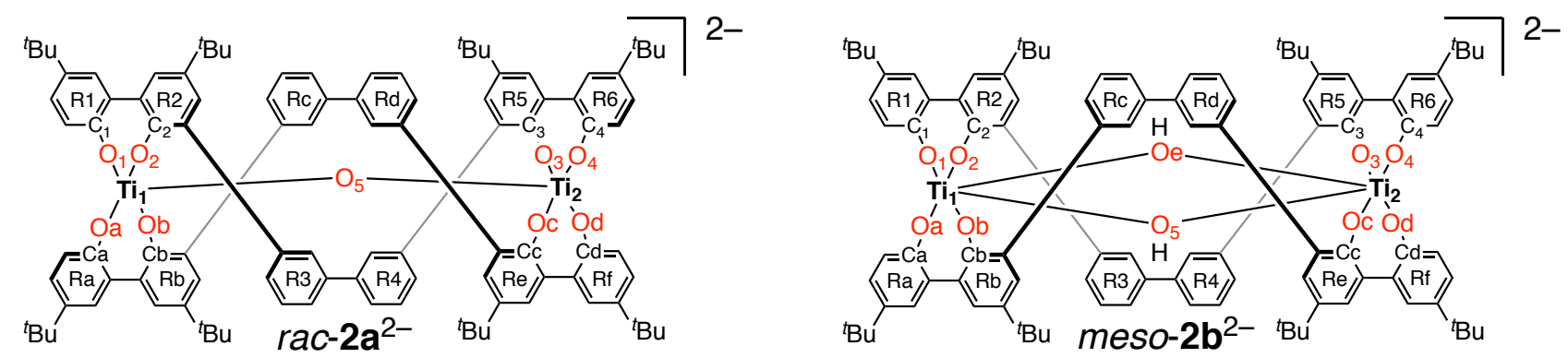

\begin{tabular}{|c|c|c|c|c|c|c|}
\hline helicate & $\begin{array}{l}d_{\mathrm{Ti}-\mathrm{Ti}} \\
(\AA)\end{array}$ & $\begin{array}{c}\text { twist angle } \\
\left({ }^{\circ}\right)^{a}\end{array}$ & & bond angle $\left(^{\circ}\right)$ & & dihedral angle $\left(^{\circ}\right)$ \\
\hline $\begin{array}{l}r a c-\mathbf{2 a}^{2-} \\
\cdot\left((S)-\mathbf{3}^{+}\right)_{2}\end{array}$ & 3.623 & $\begin{array}{c}267.25 \\
\text { (R1-R6) } \\
\\
269.78 \\
\text { (Ra-Rf) } \\
\\
\text { Average } \\
=268.52\end{array}$ & $\begin{array}{c}\mathrm{O}_{1}-\mathrm{Ti}_{1} 1-\mathrm{O}_{2} 87.80 \\
\mathrm{O}_{1}-\mathrm{Ti}_{1}-\mathrm{O}_{a} 172.20 \\
\mathrm{O}_{1}-\mathrm{Ti}_{1}-\mathrm{O}_{\mathrm{b}} 88.51 \\
\mathrm{O}_{1}-\mathrm{Ti}_{1}-\mathrm{O}_{5} 93.78 \\
\mathrm{O}_{2}-\mathrm{Ti}_{1}-\mathrm{O}_{\mathrm{a}} 88.45 \\
\mathrm{O}_{2}-\mathrm{Ti}_{1}-\mathrm{O}_{\mathrm{b}} 115.25 \\
\mathrm{O}_{2}-\mathrm{Ti}_{1}-\mathrm{O}_{5} 121.46 \\
\mathrm{O}_{\mathrm{a}}-\mathrm{Ti}_{1}-\mathrm{O}_{\mathrm{b}} 86.90 \\
\mathrm{O}_{\mathrm{a}}-\mathrm{Ti}_{1}-\mathrm{O}_{5} 94.02 \\
\mathrm{O}_{b}-\mathrm{Ti}_{1}-\mathrm{O}_{5} 123.28\end{array}$ & $\begin{array}{c}\mathrm{C}_{1}-\mathrm{O}_{1}-\mathrm{Ti}_{1} 122.46 \\
\mathrm{C}_{2}-\mathrm{O}_{2}-\mathrm{Ti}_{1} 132.47 \\
\mathrm{C}_{2}-\mathrm{O}_{2}-\mathrm{Ti}_{1} 119.75 \\
\mathrm{C}_{\mathrm{b}}-\mathrm{O}_{\mathrm{b}}-\mathrm{Ti}_{1} 132.87 \\
\mathrm{O}_{4}-\mathrm{Ti}_{2}-\mathrm{O}_{3} 87.80 \\
\mathrm{O}_{4}-\mathrm{Ti}_{2}-\mathrm{O}_{\mathrm{d}} 172.20 \\
\mathrm{O}_{4}-\mathrm{Ti}_{2}-\mathrm{O}_{\mathrm{c}} 88.51 \\
\mathrm{O}_{4}-\mathrm{Ti}_{2}-\mathrm{O}_{5} 93.78 \\
\mathrm{O}_{3}-\mathrm{Ti}_{2}-\mathrm{O}_{\mathrm{d}} 88.45 \\
\mathrm{O}_{3}-\mathrm{Ti}_{2}-\mathrm{O}_{\mathrm{c}} 115.25\end{array}$ & $\begin{array}{c}\mathrm{O}_{3}-\mathrm{Ti}_{2}-\mathrm{O}_{5} \\
121.46 \\
\mathrm{O}_{\mathrm{c}}-\mathrm{Ti}_{2}-\mathrm{O}_{5} \\
\mathrm{O}_{\mathrm{d}}-\mathrm{Ti}_{2}-\mathrm{O}_{\mathrm{c}} 86.90 \\
\mathrm{O}_{\mathrm{d}}-\mathrm{Ti}_{2}-\mathrm{O}_{5} 94.02 \\
\mathrm{C}_{4}-\mathrm{O}_{4}-\mathrm{Ti}_{2} 122.46 \\
\mathrm{C}_{3}-\mathrm{O}_{3}-\mathrm{Ti}_{2} 132.47 \\
\mathrm{C}_{\mathrm{d}}-\mathrm{O}_{\mathrm{d}}-\mathrm{Ti}_{2} 119.75 \\
\mathrm{C}_{\mathrm{c}}-\mathrm{O}_{\mathrm{c}}-\mathrm{Ti}_{2} 132.87 \\
\mathrm{Ti}_{1}-\mathrm{O}_{5}-\mathrm{Ti}_{2} 174.84\end{array}$ & $\begin{array}{l}\mathrm{R}_{1}-\mathrm{R}_{2} / \mathrm{R}_{\mathrm{a}}-\mathrm{R}_{\mathrm{b}} \\
=-44.82 /-45.94 \\
\mathrm{R}_{2}-\mathrm{R}_{3} / \mathrm{R}_{\mathrm{b}}-\mathrm{R}_{\mathrm{c}} \\
=+61.54 /+58.85 \\
\mathrm{R}_{3}-\mathrm{R}_{4} / \mathrm{R}_{\mathrm{c}}-\mathrm{R}_{\mathrm{d}} \\
=-40.78 /-40.80 \\
\mathrm{R}_{4}-\mathrm{R}_{5} / \mathrm{R}_{\mathrm{d}}-\mathrm{R}_{\mathrm{e}} \\
=+61.54 /+58.85 \\
\mathrm{R}_{5}-\mathrm{R}_{6} / \mathrm{R}_{\mathrm{e}}-\mathrm{R}_{\mathrm{f}} \\
=-44.82 /-45.94\end{array}$ \\
\hline $\begin{array}{c}\text { meso- } \mathbf{2} \mathbf{b}^{2-} \\
\cdot\left(\mathrm{Na}^{+}\right)_{2}\end{array}$ & 3.382 & $\begin{array}{c}-1.38 \\
\text { (Ra-Rf) } \\
\text { Average } \\
=+0.52\end{array}$ & 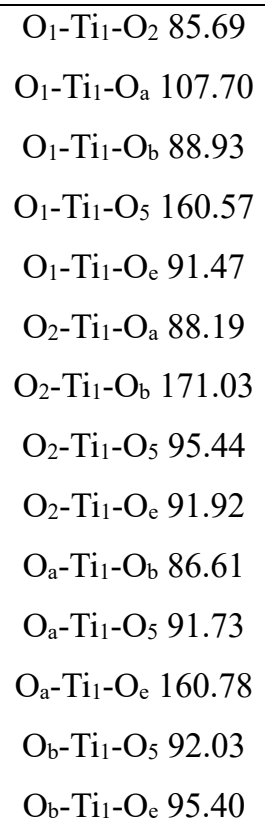 & $\begin{array}{c}\mathrm{C}_{1}-\mathrm{O}_{1}-\mathrm{Ti}_{1} 133.18 \\
\mathrm{C}_{2}-\mathrm{O}_{2}-\mathrm{Ti}_{1} 122.54 \\
\mathrm{C}_{2}-\mathrm{O}_{2}-\mathrm{Ti}_{1} 130.19 \\
\mathrm{C}_{b}-\mathrm{O}_{b}-\mathrm{Ti}_{1} 122.94 \\
\mathrm{O}_{5}-\mathrm{Ti}_{1}-\mathrm{O}_{\mathrm{e}} 69.12 \\
\mathrm{O}_{5}-\mathrm{Ti}_{2}-\mathrm{O}_{\mathrm{e}} 69.05 \\
\mathrm{O}_{4}-\mathrm{Ti}_{2}-\mathrm{O}_{3} 85.65 \\
\mathrm{O}_{4}-\mathrm{Ti}_{2}-\mathrm{O}_{\mathrm{d}} 108.51 \\
\mathrm{O}_{4}-\mathrm{Ti}_{2}-\mathrm{O}_{c} 88.17 \\
\mathrm{O}_{4}-\mathrm{Ti}_{2}-\mathrm{O}_{5} 160.47 \\
\mathrm{O}_{4}-\mathrm{Ti}_{2}-\mathrm{O}_{\mathrm{e}} 91.48 \\
\mathrm{O}_{3}-\mathrm{Ti}_{2}-\mathrm{O}_{d} 88.87 \\
\mathrm{O}_{3}-\mathrm{Ti}_{2}-\mathrm{O}_{c} 170.85\end{array}$ & $\begin{array}{l}\mathrm{O}_{3}-\mathrm{Ti}_{2}-\mathrm{O}_{5} 95.95 \\
\mathrm{O}_{3}-\mathrm{Ti}_{2}-\mathrm{O}_{\mathrm{e}} 91.17 \\
\mathrm{O}_{\mathrm{c}}-\mathrm{Ti}_{2}-\mathrm{O}_{5} 92.13 \\
\mathrm{O}_{c}-\mathrm{Ti}_{2}-\mathrm{O}_{\mathrm{e}} 95.73 \\
\mathrm{O}_{\mathrm{d}-\mathrm{Ti}}-\mathrm{O}_{\mathrm{c}} 86.70 \\
\mathrm{O}_{\mathrm{d}}-\mathrm{Ti}_{2}-\mathrm{O}_{5} 91.00 \\
\mathrm{O}_{\mathrm{d}}-\mathrm{Ti}_{2}-\mathrm{O}_{\mathrm{e}} 159.95 \\
\mathrm{C}_{4}-\mathrm{O}_{4}-\mathrm{Ti}_{2} 127.71 \\
\mathrm{C}_{3}-\mathrm{O}_{3}-\mathrm{Ti}_{2} 123.63 \\
\mathrm{C}_{\mathrm{d}}-\mathrm{O}_{\mathrm{d}}-\mathrm{Ti}_{2} 130.03 \\
\mathrm{C}_{\mathrm{c}}-\mathrm{O}_{\mathrm{c}}-\mathrm{Ti}_{2} 121.84 \\
\mathrm{Ti}_{1}-\mathrm{O}_{5}-\mathrm{Ti}_{2} 110.91 \\
\mathrm{Ti}_{1}-\mathrm{O}_{\mathrm{e}}-\mathrm{Ti}_{2} 110.92\end{array}$ & $\begin{array}{l}\mathrm{R}_{1}-\mathrm{R}_{2} / \mathrm{R}_{\mathrm{a}}-\mathrm{R}_{\mathrm{b}} \\
=-45.92 /-50.39 \\
\mathrm{R}_{2}-\mathrm{R}_{3} / \mathrm{R}_{\mathrm{b}}-\mathrm{R}_{\mathrm{c}} \\
=-36.16 /-38.29 \\
\mathrm{R}_{3}-\mathrm{R}_{4} / \mathrm{R}_{\mathrm{c}}-\mathrm{R}_{\mathrm{d}} \\
=+2.08 /+7.91 \\
\mathrm{R}_{4}-\mathrm{R}_{5} / \mathrm{R}_{\mathrm{d}}-\mathrm{R}_{\mathrm{e}} \\
=+33.56 /+29.56 \\
\mathrm{R}_{5}-\mathrm{R}_{6} / \mathrm{R}_{\mathrm{e}}-\mathrm{R}_{\mathrm{f}} \\
=+49.67 /+52.79\end{array}$ \\
\hline
\end{tabular}

\footnotetext{
${ }^{a}$ Twist angles between the two terminal benzene rings (R1 and R6, Ra and Rf) of each strand.
} 


\section{Theoretical Studies on the Structures of the Racemo-Titanium Helicates (rac-2a ${ }^{2-}$ and rac-}

$2 \mathrm{~d}^{2-}$ ) and Meso-Titanium Helicates (meso- $2 \mathrm{~b}^{2-}$ and $m e s o-2 \mathrm{c}^{2-}$ ).

The molecular modeling was performed on a Windows 7 PC with the ArgusLab software. ${ }^{\mathrm{S} 7}$ The initial structures of $\mathrm{rac}-\mathbf{2 a}^{2-}$ and meso-2 $\mathbf{b}^{2-}$ were taken from the corresponding crystal structures and those of $\mathrm{rac}-\mathbf{2} \mathbf{d}^{2-}$ and meso-2 $\mathbf{c}^{2-}$ were constructed using the crystal structures of $\mathrm{rac}-\mathbf{2} \mathbf{a}^{2-}$ and meso$\mathbf{2 b}^{2-}$ by replacing $\mu$-oxo and bis( $\mu$-hydroxo) bridges with bis( $\mu$-hydroxo) and $\mu$-oxo bridges, respectively. The initial models of rac-2 $\mathbf{a}^{2-}$, meso- $\mathbf{2} \mathbf{b}^{2-}$, and $r a c-\mathbf{2} \mathbf{d}^{2-}$ were then fully optimized and refined by the density functional theory (DFT) calculations using the dispersion corrected B3LYP (B3LYP-D3) $^{\mathrm{S} 8}$ functional with the LANL2DZ (for titanium ions) and the 6-31G* (for H, B, C, N, and $\mathrm{O}$ atoms) basis sets in Gaussian 16 software (Gaussian, Inc., Pittsburgh, PA). ${ }^{\mathrm{S} 9}$ The initial model of meso-2 $\mathbf{c}^{2-}$ was first optimized by the semiempirical molecular orbital (MO) calculations (PM6 method $^{\mathrm{S} 10}$ in MOPAC2012 ${ }^{\mathrm{S} 11}$ ) and the geometries were further refined by the DFT calculations using the B3LYP-D3 ${ }^{\mathrm{S} 8}$ functional with the LANL2DZ (for titanium ions) and the $6-31 \mathrm{G}^{*}$ (for $\mathrm{H}, \mathrm{B}, \mathrm{C}, \mathrm{N}$, and $\mathrm{O}$ atoms) basis sets in Gaussian 16 software. ${ }^{\mathrm{S} 9}$ Computer resources for the DFT calculations were provided by the Information Technology Center of Nagoya University. The resultant energyminimized structures are depicted in Figure S21. 
(a) $r a c-2 a^{2-}$


$\Delta E=0 \mathrm{kcal} / \mathrm{mol}$

(c) $m e s o-2 c^{2-}$
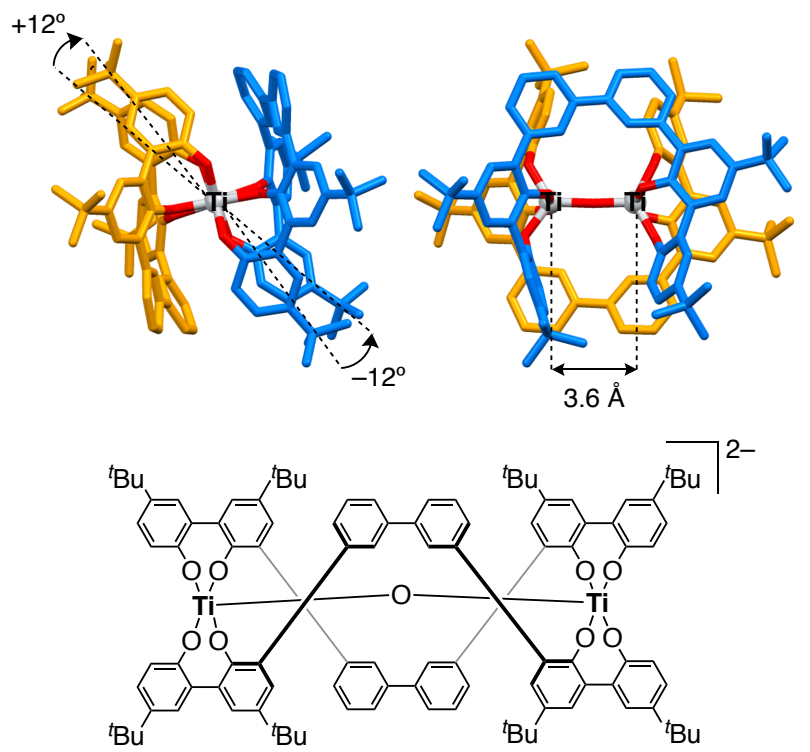

$$
\Delta E=E_{m e s o-2 c}^{2-}-E_{r a c-2 a^{2-}}
$$$$
=+7.59 \mathrm{kcal} / \mathrm{mol}
$$

(b) $m e s o-2 b^{2-}$
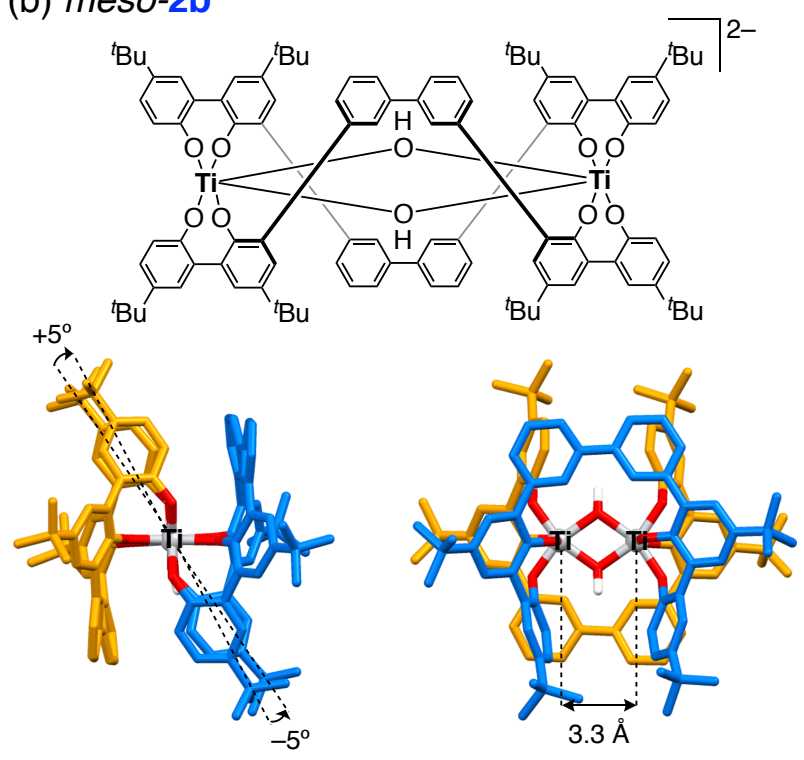

$\Delta E=0 \mathrm{kcal} / \mathrm{mol}$

(d) $r a c-2 d^{2-}$


Figure S21. Capped-stick representations of the DFT-calculated energy-minimized structures of

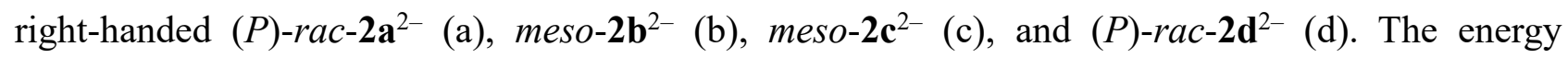
difference $(\Delta E)$ values are also shown. All the hydrogen atoms are omitted for clarity. 
(a) rac-2a ${ }^{2-}$
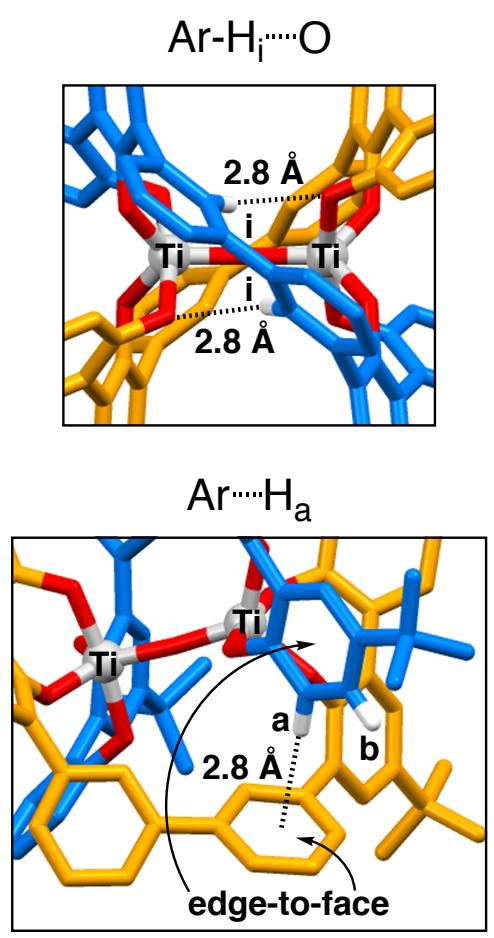

(b) $m e s o-2 b^{2-}$



Ar $\cdots \cdot \mathrm{H}_{\mathrm{a}}$

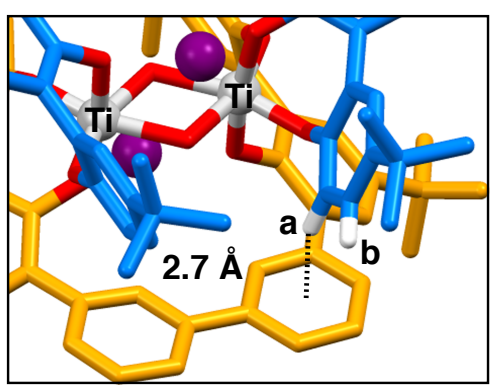

(c) $m e s o-2 c^{2-}$

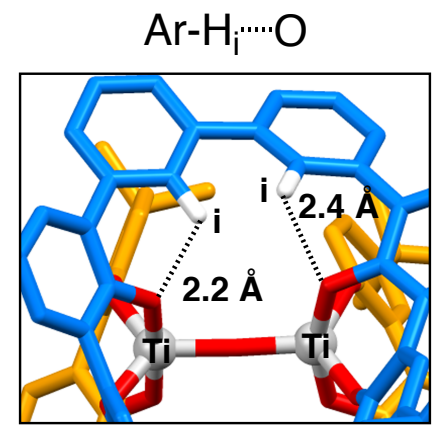

$\operatorname{Ar} \cdots \cdot H_{a}$

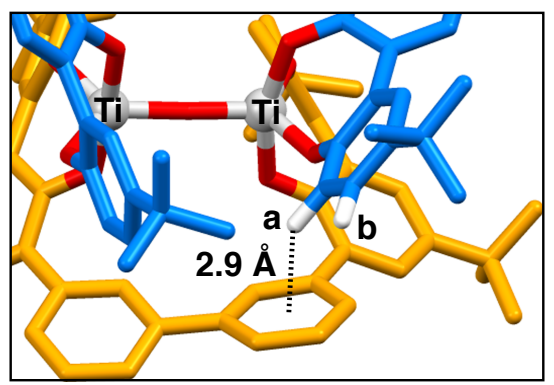

Figure S22. Expanded capped-stick representations of the X-ray crystal structures of right-handed $(P)-r a c-2 \mathbf{a}^{2-} \cdot\left((S)-\mathbf{3}^{+}\right)_{2}$ (a) and meso-2 $\mathbf{b}^{2-} \cdot\left(\mathrm{Na}^{+}\right)_{2}$ (b) and the DFT-calculated energy-minimized structure of $m e s o-2 \mathrm{c}^{2-}(\mathrm{c})$. All the hydrogen atoms are omitted for clarity. 
Table S4. Selected Bond Distances $\left(d_{\mathrm{Ti}-\mathrm{Ti}}\right)$ between Two Titanium Atoms, Bond Angles, and Dihedral Angles of the DFT-Calculated Energy-Minimized Structures of Right-Handed (P)-rac$2 \mathrm{a}^{2-}$, meso- $2 \mathrm{~b}^{2-}$, meso-2 $\mathrm{c}^{2-}$, and $(P)-r a c-2 \mathrm{~d}^{2-}$
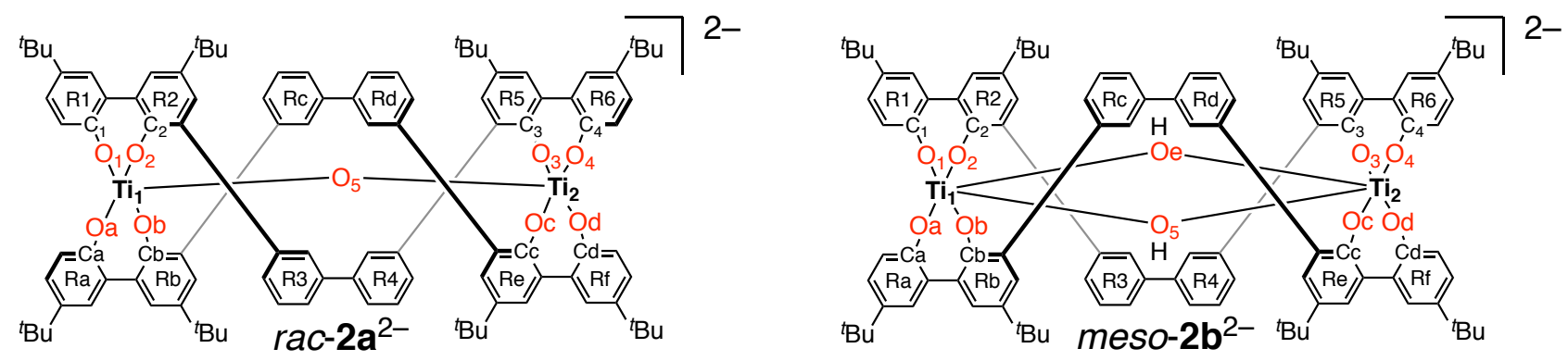

\begin{tabular}{|c|c|c|c|c|c|c|}
\hline helicate & $\begin{array}{c}d_{\mathrm{Ti}-\mathrm{Ti}} \\
(\AA)\end{array}$ & $\begin{array}{c}\text { twist angle } \\
\left({ }^{\circ}\right)^{a}\end{array}$ & & bond angle $\left(^{\circ}\right)$ & & dihedral angle $\left(^{\circ}\right)$ \\
\hline$r a c-2 \mathbf{a}^{2-}$ & 3.596 & $\begin{array}{c}264.49 \\
\text { (R1-R6) } \\
266.02 \\
\text { (Ra-Rf) } \\
\text { Average } \\
=265.26\end{array}$ & $\begin{array}{c}\mathrm{O}_{1}-\mathrm{Ti}_{1}-\mathrm{O}_{2} 86.97 \\
\mathrm{O}_{1}-\mathrm{Ti}_{1}-\mathrm{O}_{a} 175.42 \\
\mathrm{O}_{1}-\mathrm{Ti} \mathrm{i}_{1}-\mathrm{O}_{b} 90.80 \\
\mathrm{O}_{1}-\mathrm{Ti}_{1}-\mathrm{O}_{5} 92.36 \\
\mathrm{O}_{2}-\mathrm{Ti}_{1}-\mathrm{O}_{a} 90.21 \\
\mathrm{O}_{2}-\mathrm{Ti}_{1}-\mathrm{O}_{b} 116.25 \\
\mathrm{O}_{2}-\mathrm{Ti}_{1}-\mathrm{O}_{5} 122.01 \\
\mathrm{O}_{\mathrm{a}}-\mathrm{Ti}_{1}-\mathrm{O}_{b} 87.21 \\
\mathrm{O}_{\mathrm{a}}-\mathrm{Ti}_{1}-\mathrm{O}_{5} 92.19 \\
\mathrm{O}_{\mathrm{b}}-\mathrm{Ti}_{1}-\mathrm{O}_{5} 121.75\end{array}$ & 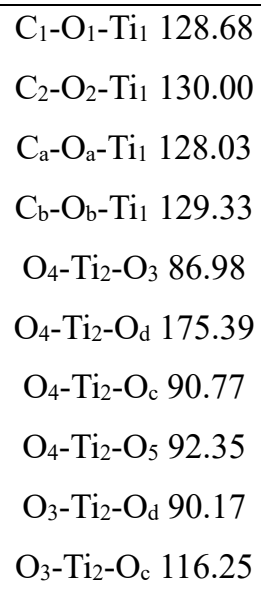 & $\begin{array}{l}\mathrm{O}_{3}-\mathrm{Ti}_{2}-\mathrm{O}_{5} 122.03 \\
\mathrm{O}_{c}-\mathrm{Ti}_{2}-\mathrm{O}_{5} 121.71 \\
\mathrm{O}_{d}-\mathrm{Ti}_{2}-\mathrm{O}_{c} 87.23 \\
\mathrm{O}_{d}-\mathrm{Ti}_{2}-\mathrm{O}_{5} 92.24 \\
\mathrm{C}_{4}-\mathrm{O}_{4}-\mathrm{Ti}_{2} 128.60 \\
\mathrm{C}_{3}-\mathrm{O}_{3}-\mathrm{Ti}_{2} 130.18 \\
\mathrm{C}_{d}-\mathrm{O}_{d}-\mathrm{Ti}_{2} 127.92 \\
\mathrm{C}_{c}-\mathrm{O}_{c}-\mathrm{Ti}_{2} 129.42 \\
\mathrm{Ti}_{1}-\mathrm{O}_{5}-\mathrm{Ti}_{2} 179.45\end{array}$ & $\begin{array}{l}\mathrm{R}_{1}-\mathrm{R}_{2} / \mathrm{R}_{\mathrm{a}}-\mathrm{R}_{\mathrm{b}} \\
=-45.83 /-46.80 \\
\mathrm{R}_{2}-\mathrm{R}_{3} / \mathrm{R}_{\mathrm{b}}-\mathrm{R}_{\mathrm{c}} \\
=+64.53 /+65.29 \\
\mathrm{R}_{3}-\mathrm{R}_{4} / \mathrm{R}_{\mathrm{c}}-\mathrm{R}_{\mathrm{d}} \\
=-44.26 /-42.41 \\
\mathrm{R}_{4}-\mathrm{R}_{5} / \mathrm{R}_{\mathrm{d}}-\mathrm{R}_{\mathrm{e}} \\
=+64.16 /+64.96 \\
\mathrm{R}_{5}-\mathrm{R}_{6} / \mathrm{R}_{\mathrm{e}}-\mathrm{R}_{\mathrm{f}} \\
=-45.75 /-46.91\end{array}$ \\
\hline meso-2 $\mathbf{b}^{2-}$ & 3.299 & $\begin{array}{c}-4.74 \\
(\mathrm{R} 1-\mathrm{R} 6) \\
-6.12 \\
\text { (Ra-Rf) } \\
\text { Average } \\
=-5.43\end{array}$ & $\begin{array}{c}\mathrm{O}_{1}-\mathrm{Ti}_{1}-\mathrm{O}_{2} 85.09 \\
\mathrm{O}_{1}-\mathrm{Ti}_{1}-\mathrm{O}_{\mathrm{a}} 108.45 \\
\mathrm{O}_{1}-\mathrm{Ti}_{1}-\mathrm{O}_{\mathrm{b}} 87.30 \\
\mathrm{O}_{1}-\mathrm{Ti}_{1}-\mathrm{O}_{5} 160.89 \\
\mathrm{O}_{1}-\mathrm{Ti}_{1}-\mathrm{O}_{\mathrm{e}} 90.59 \\
\mathrm{O}_{2}-\mathrm{Ti}_{1}-\mathrm{O}_{\mathrm{a}} 87.25 \\
\mathrm{O}_{2}-\mathrm{Ti}_{1}-\mathrm{O}_{\mathrm{b}} 166.93 \\
\mathrm{O}_{2}-\mathrm{Ti}_{1}-\mathrm{O}_{5} 96.01 \\
\mathrm{O}_{2}-\mathrm{Ti}_{1}-\mathrm{O}_{\mathrm{e}} 95.00 \\
\mathrm{O}_{\mathrm{a}}-\mathrm{Ti}_{1}-\mathrm{O}_{\mathrm{b}} 85.11 \\
\mathrm{O}_{\mathrm{a}}-\mathrm{Ti}_{1}-\mathrm{O}_{5} 90.67 \\
\mathrm{O}_{\mathrm{a}}-\mathrm{Ti}_{1}-\mathrm{O}_{\mathrm{e}} 160.96 \\
\mathrm{O}_{\mathrm{b}}-\mathrm{Ti}_{1}-\mathrm{O}_{5} 94.66 \\
\mathrm{O}_{\mathrm{b}}-\mathrm{Ti}_{1}-\mathrm{O}_{\mathrm{e}} 95.68\end{array}$ & 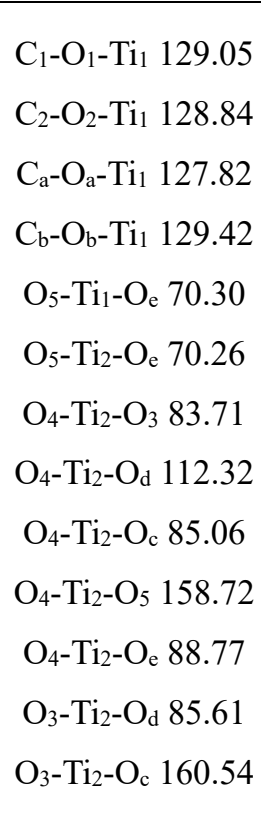 & $\begin{array}{l}\mathrm{O}_{3}-\mathrm{Ti}_{2}-\mathrm{O}_{5} 95.91 \\
\mathrm{O}_{3}-\mathrm{Ti}_{2}-\mathrm{O}_{\mathrm{e}} 99.44 \\
\mathrm{O}_{\mathrm{c}}-\mathrm{Ti}_{2}-\mathrm{O}_{5} 100.28 \\
\mathrm{O}_{\mathrm{c}}-\mathrm{Ti}_{2}-\mathrm{O}_{\mathrm{e}} 96.15 \\
\mathrm{O}_{\mathrm{d}}-\mathrm{Ti}_{2}-\mathrm{O}_{\mathrm{c}} 84.03 \\
\mathrm{O}_{\mathrm{d}}-\mathrm{Ti}_{2}-\mathrm{O}_{5} 88.81 \\
\mathrm{O}_{\mathrm{d}}-\mathrm{Ti}_{2}-\mathrm{O}_{\mathrm{e}} 158.80 \\
\mathrm{C}_{4}-\mathrm{O}_{4}-\mathrm{Ti}_{2} 130.10 \\
\mathrm{C}_{3}-\mathrm{O}_{3}-\mathrm{Ti}_{2} 126.56 \\
\mathrm{C}_{\mathrm{d}}-\mathrm{O}_{\mathrm{d}}-\mathrm{Ti}_{2} 131.21 \\
\mathrm{C}_{\mathrm{c}}-\mathrm{O}_{\mathrm{c}}-\mathrm{Ti}_{2} 125.91 \\
\mathrm{Ti}_{1}-\mathrm{O}_{5}-\mathrm{Ti}_{2} 109.68 \\
\mathrm{Ti}_{1}-\mathrm{O}_{\mathrm{e}}-\mathrm{Ti}_{2} 109.76\end{array}$ & $\begin{array}{l}\mathrm{R}_{1}-\mathrm{R}_{2} / \mathrm{R}_{\mathrm{a}}-\mathrm{R}_{\mathrm{b}} \\
=-47.25 /-48.36 \\
\mathrm{R}_{2}-\mathrm{R}_{3} / \mathrm{R}_{\mathrm{b}}-\mathrm{R}_{\mathrm{c}} \\
=-30.68 /-31.47 \\
\mathrm{R}_{3}-\mathrm{R}_{4} / \mathrm{R}_{\mathrm{c}}-\mathrm{R}_{\mathrm{d}} \\
=-15.87 /-14.94 \\
\mathrm{R}_{4}-\mathrm{R}_{5} / \mathrm{R}_{\mathrm{d}}-\mathrm{R}_{\mathrm{e}} \\
=+39.94 /+39.37 \\
\mathrm{R}_{5}-\mathrm{R}_{6} / \mathrm{R}_{\mathrm{e}}-\mathrm{R}_{\mathrm{f}} \\
=+45.93 /+46.34\end{array}$ \\
\hline
\end{tabular}

(Table S4 to be continued) 


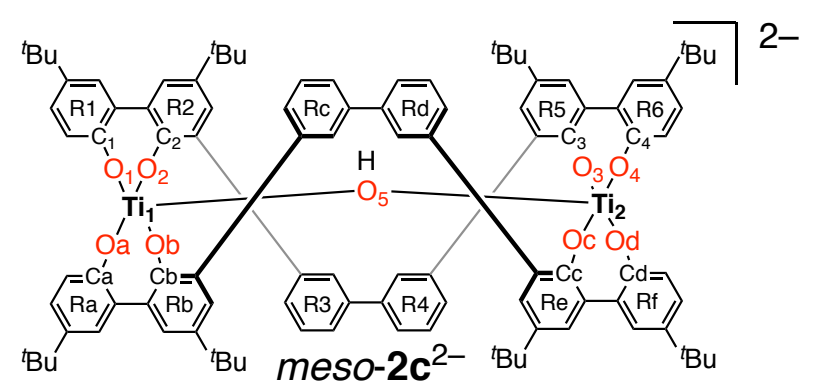

helicate $d_{\mathrm{Ti}-\mathrm{Ti}} \quad$ twist angle

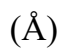

$\left({ }^{\circ}\right)^{a}$

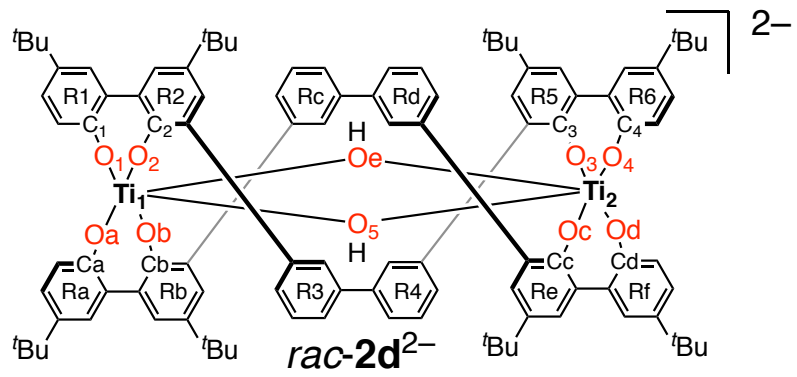

bond angle $\left(^{\circ}\right)$

dihedral angle $\left(^{\circ}\right)$

\begin{tabular}{|c|c|c|c|c|c|c|}
\hline meso-2 $\mathrm{c}^{2-}$ & 3.603 & $\begin{array}{l}-10.54 \\
(\mathrm{R} 1-\mathrm{R} 6) \\
-14.17 \\
\text { (Ra-Rf) } \\
\text { Average } \\
=-12.36\end{array}$ & $\begin{array}{c}\mathrm{O}_{1}-\mathrm{Ti}_{1}-\mathrm{O}_{2} 87.31 \\
\mathrm{O}_{1}-\mathrm{Ti}_{1}-\mathrm{O}_{\mathrm{a}} 113.40 \\
\mathrm{O}_{1}-\mathrm{Ti}_{1}-\mathrm{O}_{\mathrm{b}} 91.31 \\
\mathrm{O}_{1}-\mathrm{Ti}_{1}-\mathrm{O}_{5} 122.03 \\
\mathrm{O}_{2}-\mathrm{Ti}_{1}-\mathrm{O}_{\mathrm{a}} 90.75 \\
\mathrm{O}_{2}-\mathrm{Ti}_{1}-\mathrm{O}_{\mathrm{b}} 176.46 \\
\mathrm{O}_{2}-\mathrm{Ti}_{1}-\mathrm{O}_{5} 91.67 \\
\mathrm{O}_{\mathrm{a}}-\mathrm{Ti}_{1}-\mathrm{O}_{\mathrm{b}} 86.81 \\
\mathrm{O}_{\mathrm{a}}-\mathrm{Ti}_{1}-\mathrm{O}_{5} 124.57 \\
\mathrm{O}_{\mathrm{b}}-\mathrm{Ti}_{1}-\mathrm{O}_{5} 91.82\end{array}$ & $\begin{array}{l}\mathrm{C}_{1}-\mathrm{O}_{1}-\mathrm{Ti}_{1} 128.09 \\
\mathrm{C}_{2}-\mathrm{O}_{2}-\mathrm{Ti}_{1} 130.21 \\
\mathrm{C}_{\mathrm{a}}-\mathrm{O}_{\mathrm{a}}-\mathrm{Ti}_{1} 125.61 \\
\mathrm{C}_{\mathrm{b}}-\mathrm{O}_{\mathrm{b}}-\mathrm{Ti}_{1} 133.08 \\
\mathrm{O}_{4}-\mathrm{Ti}_{2}-\mathrm{O}_{3} 85.29 \\
\mathrm{O}_{4}-\mathrm{Ti}_{2}-\mathrm{O}_{\mathrm{d}} 126.54 \\
\mathrm{O}_{4}-\mathrm{Ti}_{2}-\mathrm{O}_{\mathrm{c}} 85.79 \\
\mathrm{O}_{4}-\mathrm{Ti}_{2}-\mathrm{O}_{5} 117.12 \\
\mathrm{O}_{3}-\mathrm{Ti}_{2}-\mathrm{O}_{\mathrm{d}} 86.35 \\
\mathrm{O}_{3}-\mathrm{Ti}_{2}-\mathrm{O}_{\mathrm{c}} 160.90\end{array}$ & $\begin{array}{l}\mathrm{O}_{3}-\mathrm{Ti}_{2}-\mathrm{O}_{5} 99.44 \\
\mathrm{O}_{c}-\mathrm{Ti}_{2}-\mathrm{O}_{5} 99.66 \\
\mathrm{O}_{\mathrm{d}}-\mathrm{Ti}_{2}-\mathrm{O}_{\mathrm{c}} 85.45 \\
\mathrm{O}_{\mathrm{d}}-\mathrm{Ti}_{2}-\mathrm{O}_{5} 116.34 \\
\mathrm{C}_{4}-\mathrm{O}_{4}-\mathrm{Ti}_{2} 135.65 \\
\mathrm{C}_{3}-\mathrm{O}_{3}-\mathrm{Ti}_{2} 122.65 \\
\mathrm{C}_{\mathrm{d}}-\mathrm{O}_{\mathrm{d}}-\mathrm{Ti}_{2} 134.68 \\
\mathrm{C}_{\mathrm{c}}-\mathrm{O}_{\mathrm{c}}-\mathrm{Ti}_{2} 122.31 \\
\mathrm{Ti}_{1}-\mathrm{O}_{5}-\mathrm{Ti}_{2} 176.14\end{array}$ & $\begin{array}{l}\mathrm{R}_{1}-\mathrm{R}_{2} / \mathrm{R}_{\mathrm{a}}-\mathrm{R}_{\mathrm{b}} \\
=-48.56 /-48.47 \\
\mathrm{R}_{2}-\mathrm{R}_{3} / \mathrm{R}_{\mathrm{b}}-\mathrm{R}_{\mathrm{c}} \\
=-32.24 /-33.61 \\
\mathrm{R}_{3}-\mathrm{R}_{4} / \mathrm{R}_{\mathrm{c}}-\mathrm{R}_{\mathrm{d}} \\
=-23.00 /-22.99 \\
\mathrm{R}_{4}-\mathrm{R}_{5} / \mathrm{R}_{\mathrm{d}}-\mathrm{R}_{\mathrm{e}} \\
=+41.76 /+40.75 \\
\mathrm{R}_{5}-\mathrm{R}_{6} / \mathrm{R}_{\mathrm{e}}-\mathrm{R}_{\mathrm{f}} \\
=+45.77 /+46.37\end{array}$ \\
\hline$r a c-\mathbf{2} \mathbf{d}^{2-}$ & 3.263 & $\begin{array}{l}295.19 \\
\text { (Ra-Rf) } \\
\text { Average } \\
=294.93\end{array}$ & $\begin{array}{c}\mathrm{O}_{1}-\mathrm{Ti}_{1}-\mathrm{O}_{2} 81.67 \\
\mathrm{O}_{1}-\mathrm{Ti}_{1}-\mathrm{O}_{\mathrm{a}} 152.32 \\
\mathrm{O}_{1}-\mathrm{Ti}_{1}-\mathrm{O}_{\mathrm{b}} 85.00 \\
\mathrm{O}_{1}-\mathrm{Ti}_{1}-\mathrm{O}_{5} 129.63 \\
\mathrm{O}_{1}-\mathrm{Ti}_{1}-\mathrm{O}_{\mathrm{e}} 75.67 \\
\mathrm{O}_{2}-\mathrm{Ti}_{1}-\mathrm{O}_{\mathrm{a}} 85.04 \\
\mathrm{O}_{2}-\mathrm{Ti}_{1}-\mathrm{O}_{\mathrm{b}} 121.44 \\
\mathrm{O}_{2}-\mathrm{Ti}_{1}-\mathrm{O}_{5} 94.79 \\
\mathrm{O}_{2}-\mathrm{Ti}_{1}-\mathrm{O}_{\mathrm{e}} 135.14 \\
\mathrm{O}_{\mathrm{a}}-\mathrm{Ti}_{1}-\mathrm{O}_{\mathrm{b}} 81.40 \\
\mathrm{O}_{\mathrm{a}}-\mathrm{Ti}_{1}-\mathrm{O}_{5} 75.50 \\
\mathrm{O}_{\mathrm{a}}-\mathrm{Ti}_{1}-\mathrm{O}_{\mathrm{e}} 129.28 \\
\mathrm{O}_{b}-\mathrm{Ti}_{1}-\mathrm{O}_{5} 134.85 \\
\mathrm{O}_{\mathrm{b}}-\mathrm{Ti}_{1}-\mathrm{O}_{\mathrm{e}} 94.76\end{array}$ & $\begin{array}{l}\mathrm{C}_{1}-\mathrm{O}_{1}-\mathrm{Ti}_{1} 113.08 \\
\mathrm{C}_{2}-\mathrm{O}_{2}-\mathrm{Ti}_{1} 144.99 \\
\mathrm{C}_{\mathrm{a}}-\mathrm{O}_{\mathrm{a}}-\mathrm{Ti}_{1} 113.05 \\
\mathrm{C}_{\mathrm{b}}-\mathrm{O}_{\mathrm{b}}-\mathrm{Ti}_{1} 145.33 \\
\mathrm{O}_{5}-\mathrm{Ti}_{1}-\mathrm{O}_{\mathrm{e}} 72.22 \\
\mathrm{O}_{5}-\mathrm{Ti}_{2}-\mathrm{O}_{\mathrm{e}} 71.52 \\
\mathrm{O}_{4}-\mathrm{Ti}_{2}-\mathrm{O}_{3} 87.01 \\
\mathrm{O}_{4}-\mathrm{Ti}_{2}-\mathrm{O}_{\mathrm{d}} 172.92 \\
\mathrm{O}_{4}-\mathrm{Ti}_{2}-\mathrm{O}_{\mathrm{c}} 88.52 \\
\mathrm{O}_{4}-\mathrm{Ti}_{2}-\mathrm{O}_{5} 90.97 \\
\mathrm{O}_{4}-\mathrm{Ti}_{2}-\mathrm{O}_{\mathrm{e}} 94.85 \\
\mathrm{O}_{3}-\mathrm{Ti}_{2}-\mathrm{O}_{\mathrm{d}} 88.53 \\
\mathrm{O}_{3}-\mathrm{Ti}_{2}-\mathrm{O}_{\mathrm{c}} 100.84\end{array}$ & $\begin{array}{c}\mathrm{O}_{3}-\mathrm{Ti}_{2}-\mathrm{O}_{5} 93.80 \\
\mathrm{O}_{3}-\mathrm{Ti}_{2}-\mathrm{O}_{\mathrm{e}} 165.20 \\
\mathrm{O}_{\mathrm{c}}-\mathrm{Ti}_{2}-\mathrm{O}_{5} 165.30 \\
\mathrm{O}_{\mathrm{c}}-\mathrm{Ti}_{2}-\mathrm{O}_{\mathrm{e}} 93.88 \\
\mathrm{O}_{\mathrm{d}}-\mathrm{Ti}_{2}-\mathrm{O}_{\mathrm{c}} 86.92 \\
\mathrm{O}_{\mathrm{d}}-\mathrm{Ti}_{2}-\mathrm{O}_{5} 94.81 \\
\mathrm{O}_{\mathrm{d}}-\mathrm{Ti}_{2}-\mathrm{O}_{\mathrm{e}} 90.86 \\
\mathrm{C}_{4}-\mathrm{O}_{4}-\mathrm{Ti}_{2} 123.75 \\
\mathrm{C}_{3}-\mathrm{O}_{3}-\mathrm{Ti}_{2} 140.16 \\
\mathrm{C}_{\mathrm{d}}-\mathrm{O}_{\mathrm{d}}-\mathrm{Ti}_{2} 123.55 \\
\mathrm{C}_{\mathrm{c}}-\mathrm{O}_{\mathrm{c}}-\mathrm{Ti}_{2} 140.25 \\
\mathrm{Ti}_{1}-\mathrm{O}_{5}-\mathrm{Ti}_{2} 108.13 \\
\mathrm{Ti}_{1}-\mathrm{O}_{\mathrm{e}}-\mathrm{Ti}_{2} 108.13\end{array}$ & $\begin{array}{l}\mathrm{R}_{1}-\mathrm{R}_{2} / \mathrm{R}_{\mathrm{a}}-\mathrm{R}_{\mathrm{b}} \\
=-46.83 /-45.48 \\
\mathrm{R}_{2}-\mathrm{R}_{3} / \mathrm{R}_{\mathrm{b}}-\mathrm{R}_{\mathrm{c}} \\
=+45.67 /+44.36 \\
\mathrm{R}_{3}-\mathrm{R}_{4} / \mathrm{R}_{\mathrm{c}}-\mathrm{R}_{\mathrm{d}} \\
=-57.12 /-57.76 \\
\mathrm{R}_{4}-\mathrm{R}_{5} / \mathrm{R}_{\mathrm{d}}-\mathrm{R}_{\mathrm{e}} \\
=+56.93 /+57.03 \\
\mathrm{R}_{5}-\mathrm{R}_{6} / \mathrm{R}_{\mathrm{e}}-\mathrm{R}_{\mathrm{f}} \\
=-44.96 /-44.93\end{array}$ \\
\hline
\end{tabular}

${ }^{a}$ Twist angles between the two terminal benzene rings (R1 and R6, Ra and Rf) of each strand. 
8. 2D NMR (gCOSY and NOESY) Spectra of $r a c-2 a^{2-} \cdot\left(\mathrm{Na}^{+}\right)_{2}$, meso-2 $\mathrm{b}^{2-} \cdot\left(\mathrm{Na}^{+}\right)_{2}$, and meso$2 \mathrm{c}^{2-\cdot} \cdot\left(\mathrm{Na}^{+} \subset[2.2 .1]\right) 2$.
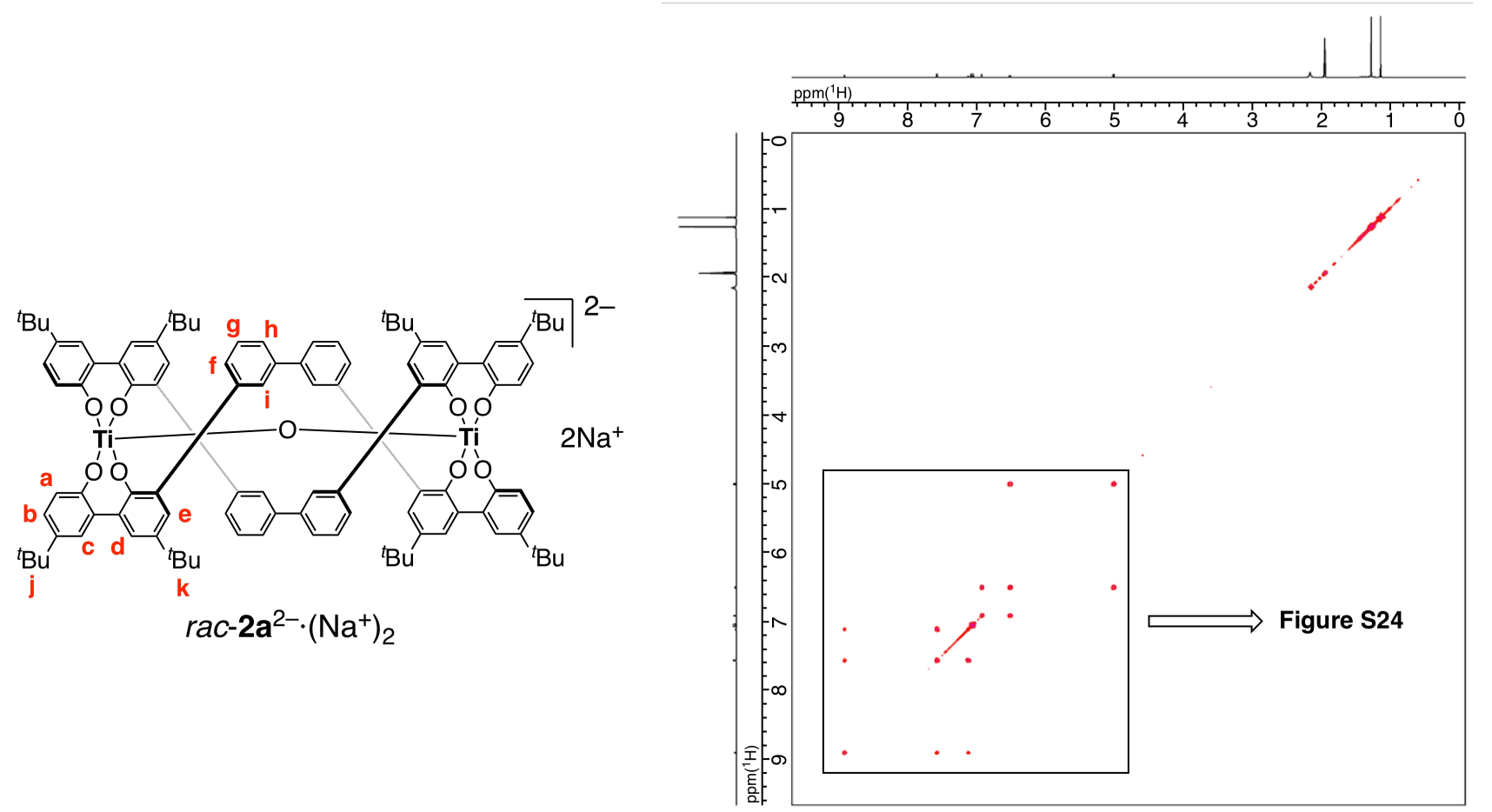

Figure S23. $g \mathrm{COSY}$ spectrum of $r a c-2 \mathbf{a}^{2-} \cdot\left(\mathrm{Na}^{+}\right)_{2}\left(500 \mathrm{MHz}, \mathrm{CD}_{3} \mathrm{CN}, 2.5 \mathrm{mM}, 25^{\circ} \mathrm{C}\right)$.

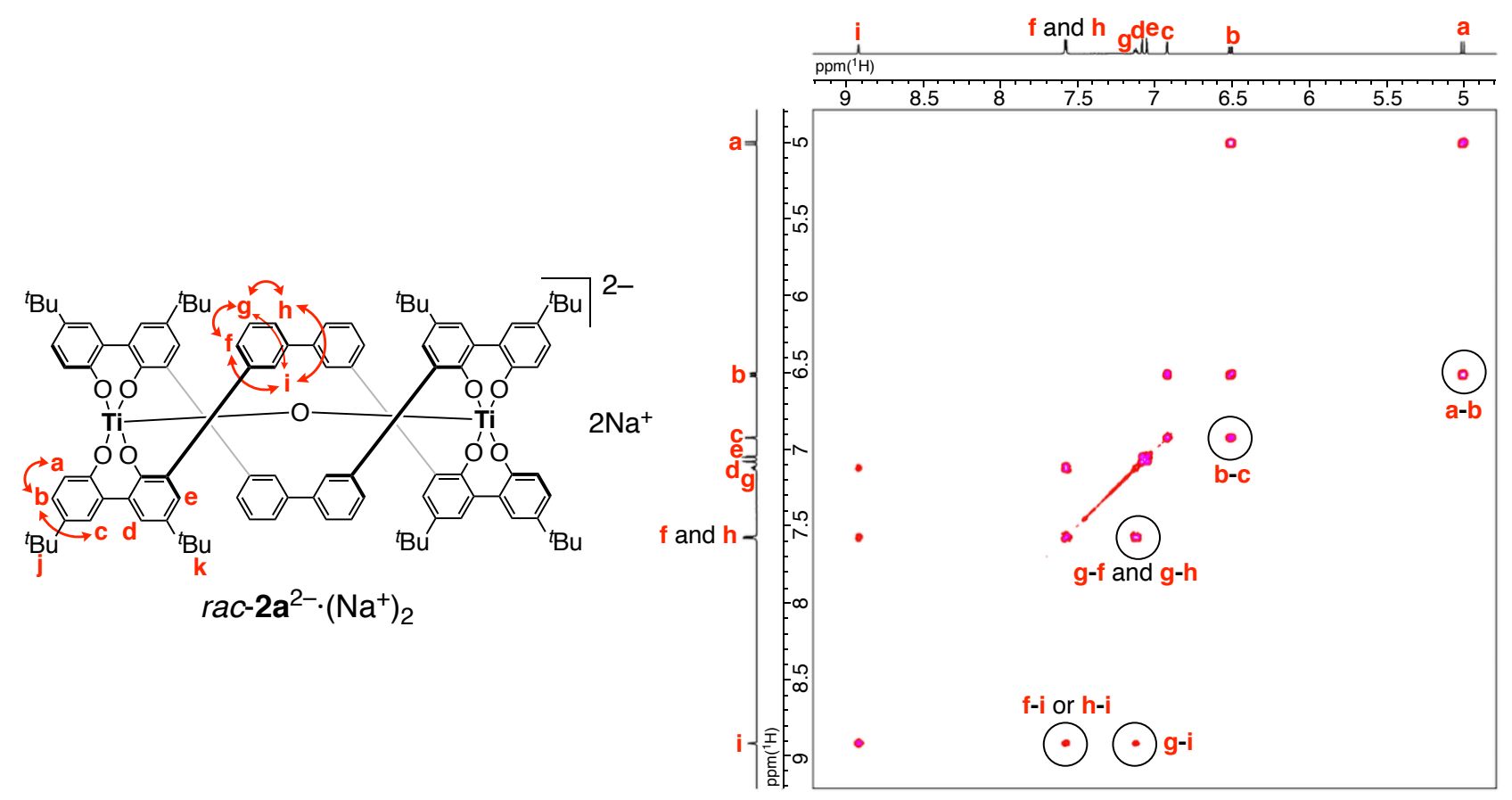

Figure S24. Partial gCOSY spectrum of $r a c-2 \mathbf{a}^{2-} \cdot\left(\mathrm{Na}^{+}\right)_{2}\left(500 \mathrm{MHz}, \mathrm{CD}_{3} \mathrm{CN}, 2.5 \mathrm{mM}, 25^{\circ} \mathrm{C}\right)$. 



Figure S25. NOESY spectrum of $r a c-2 a^{2-} \cdot\left(\mathrm{Na}^{+}\right)_{2}\left(500 \mathrm{MHz}, \mathrm{CD}_{3} \mathrm{CN}, 2.5 \mathrm{mM}, 25^{\circ} \mathrm{C}\right.$, mixing time $=500 \mathrm{~ms}$ ). 


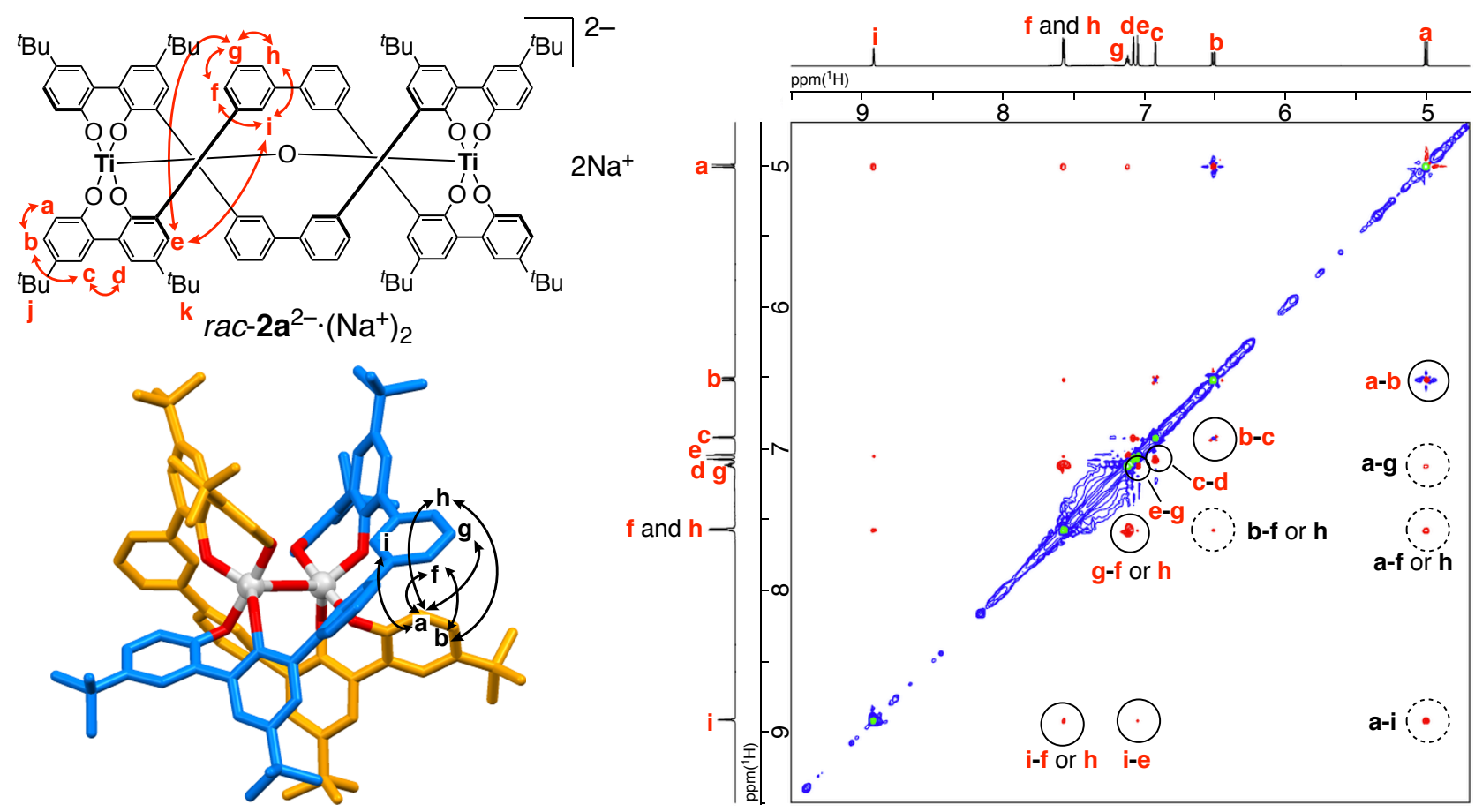

Figure S26. Partial NOESY spectrum of $r a c-2 a^{2-} \cdot\left(\mathrm{Na}^{+}\right)_{2}\left(500 \mathrm{MHz}, \mathrm{CD}_{3} \mathrm{CN}, 2.5 \mathrm{mM}, 25^{\circ} \mathrm{C}\right.$, mixing time $=500 \mathrm{~ms}$ ). Interstrand NOE cross-peaks are indicated by arrows in the crystal structure of rac-

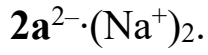

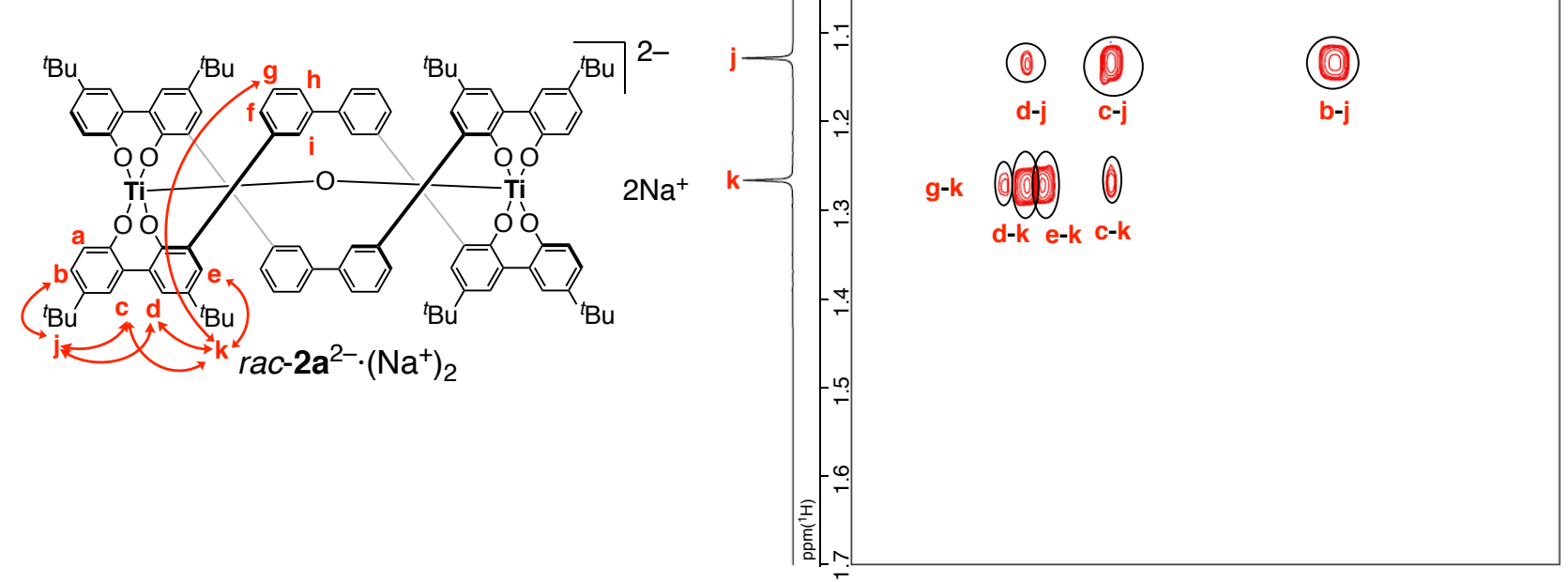

Figure S27. Partial NOESY spectrum of $\mathrm{rac}-\mathbf{2 a}^{2-} \cdot\left(\mathrm{Na}^{+}\right)_{2}\left(500 \mathrm{MHz}, \mathrm{CD}_{3} \mathrm{CN}, 2.5 \mathrm{mM}, 25^{\circ} \mathrm{C}\right.$, mixing time $=500 \mathrm{~ms})$. 


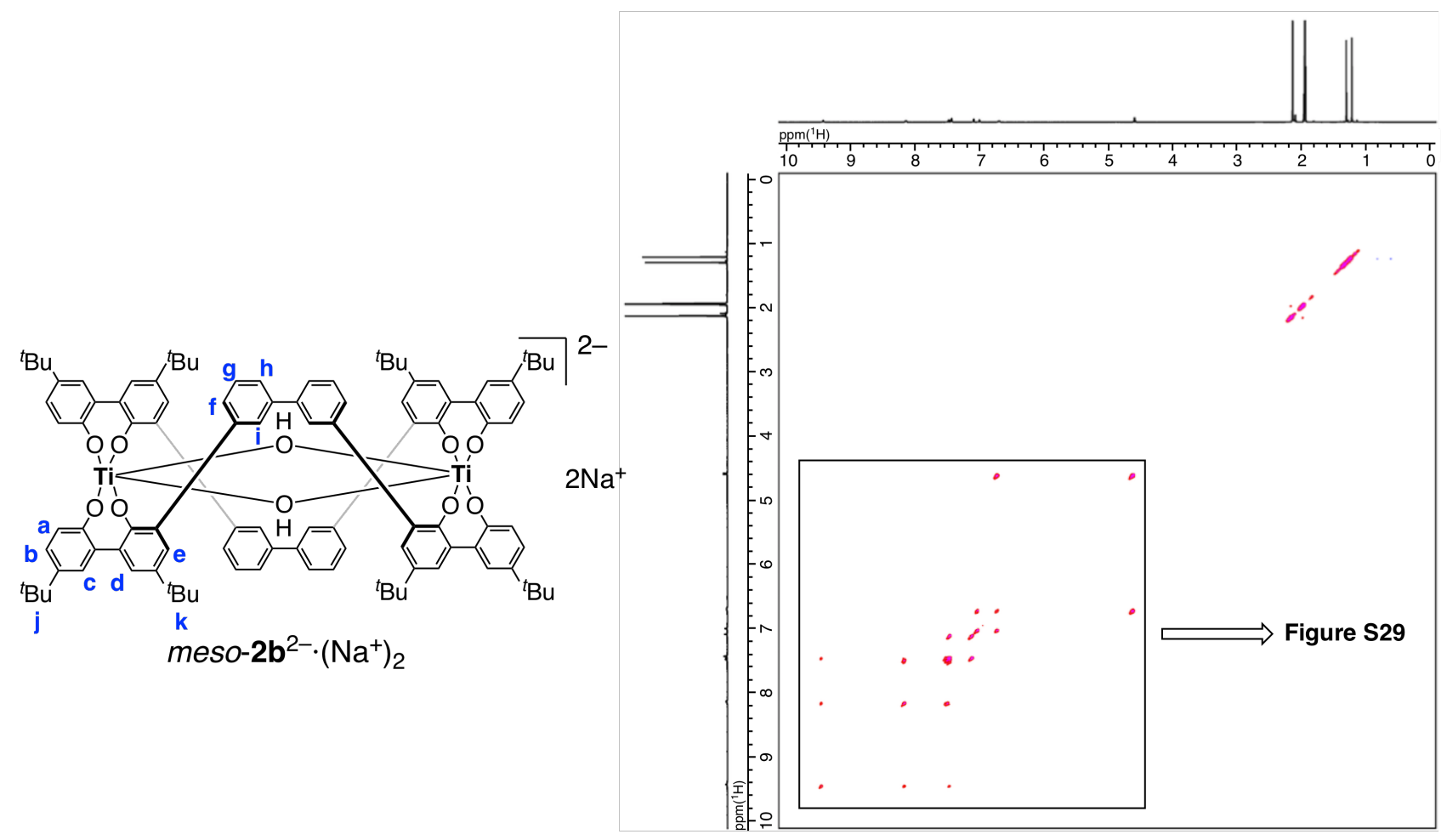

Figure S28. $g \mathrm{COSY}$ spectrum of meso-2 $\mathbf{b}^{2-} \cdot\left(\mathrm{Na}^{+}\right)_{2}\left(500 \mathrm{MHz}, \mathrm{CD}_{3} \mathrm{CN}, 2.5 \mathrm{mM}, 25^{\circ} \mathrm{C}\right)$.

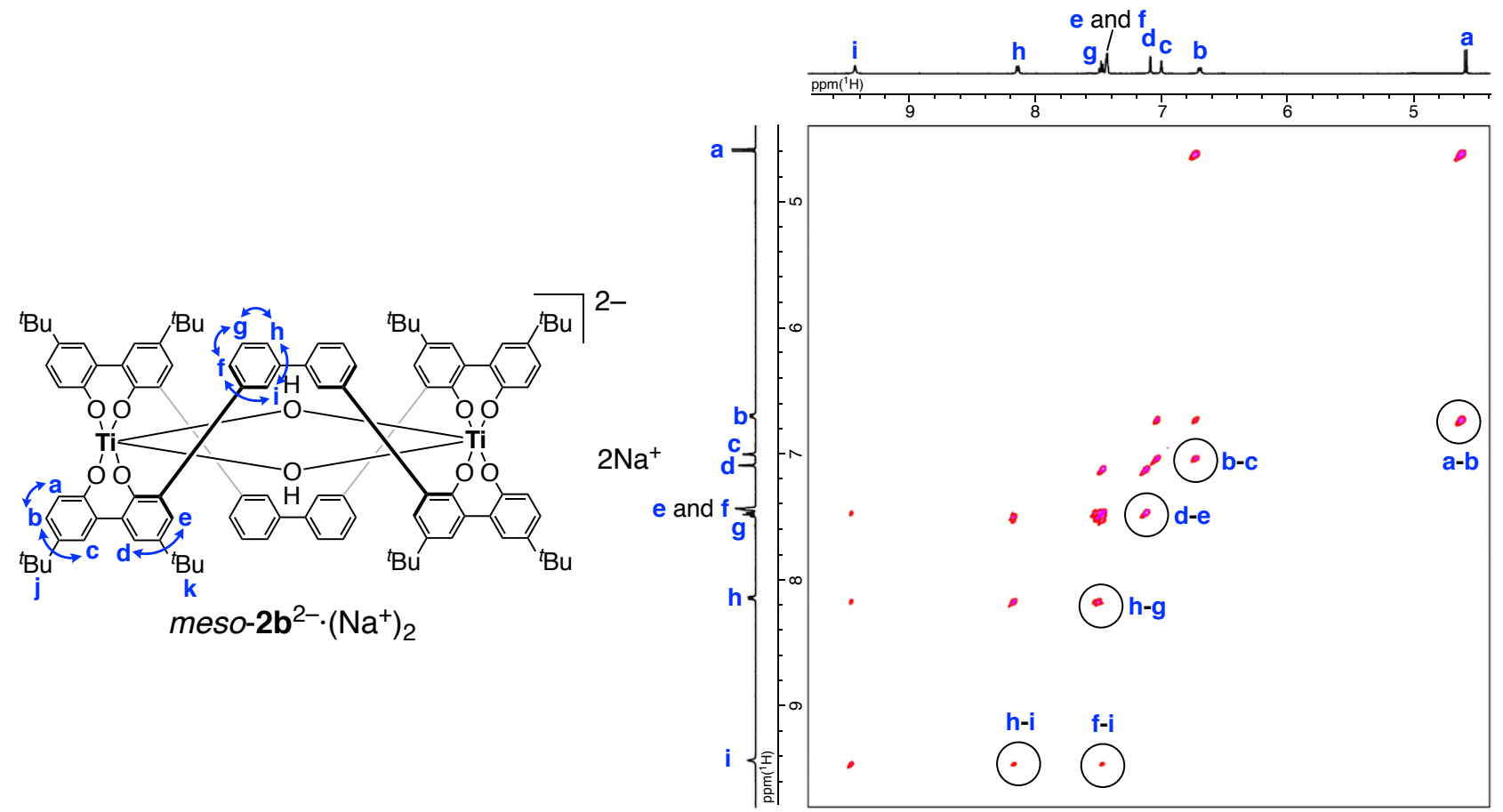

Figure S29. Partial gCOSY spectrum of meso-2 $\mathbf{b}^{2-} \cdot\left(\mathrm{Na}^{+}\right)_{2}\left(500 \mathrm{MHz}, \mathrm{CD}_{3} \mathrm{CN}, 2.5 \mathrm{mM}, 25^{\circ} \mathrm{C}\right)$. 




Figure S30. NOESY spectrum of meso-2 $\mathbf{b}^{2-} \cdot\left(\mathrm{Na}^{+}\right)_{2}\left(500 \mathrm{MHz}, \mathrm{CD}_{3} \mathrm{CN}, 2.5 \mathrm{mM}, 25^{\circ} \mathrm{C}\right.$, mixing time $=500 \mathrm{~ms})$. 


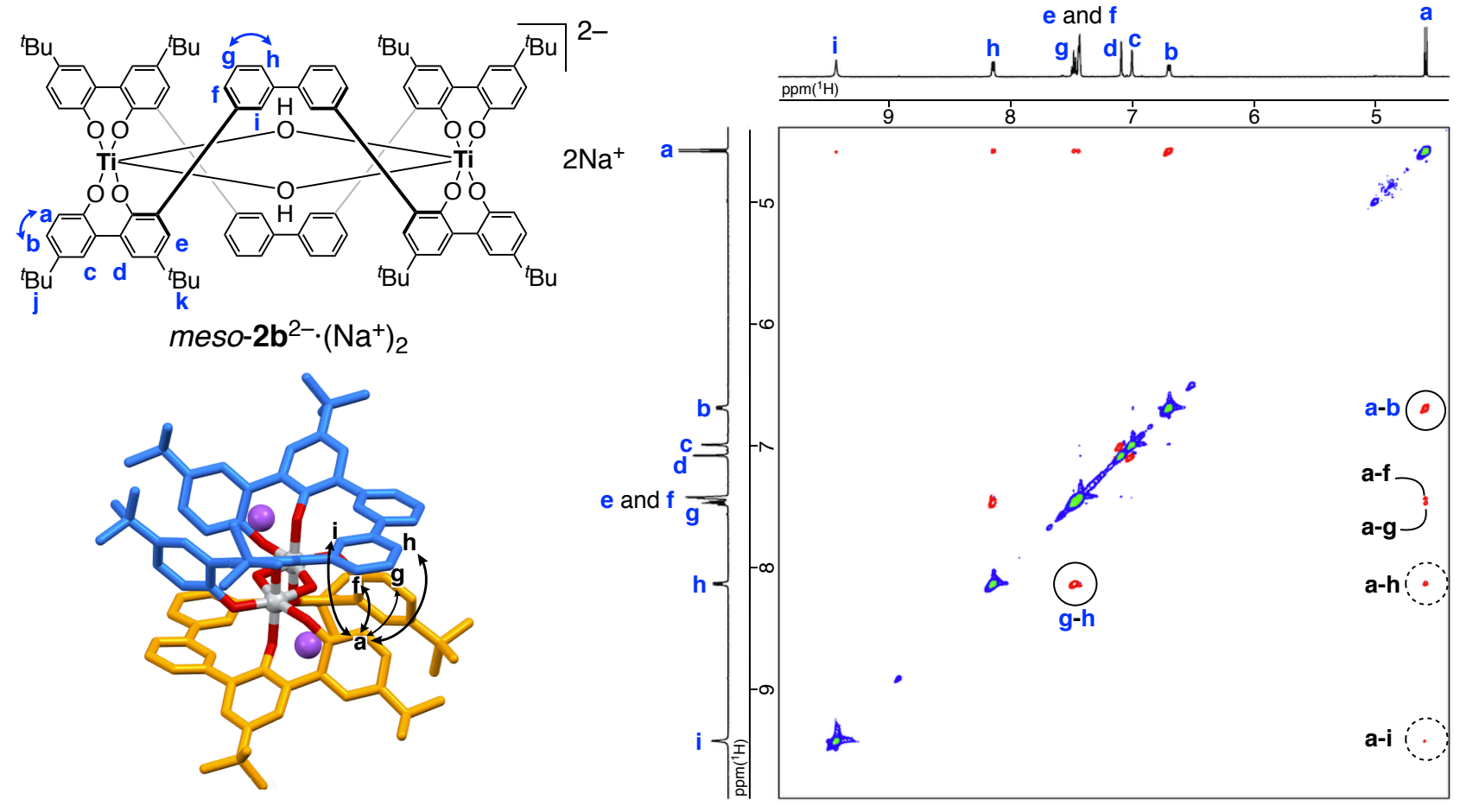

Figure S31. Partial NOESY spectrum of meso-2 $\mathbf{b}^{2-} \cdot\left(\mathrm{Na}^{+}\right)_{2}\left(500 \mathrm{MHz}, \mathrm{CD}_{3} \mathrm{CN}, 2.5 \mathrm{mM}, 25{ }^{\circ} \mathrm{C}\right.$, mixing time $=500 \mathrm{~ms}$ ). Interstrand NOE cross-peaks are indicated by arrows in the crystal structure of $m e s o-2 \mathbf{b}^{2-} \cdot\left(\mathrm{Na}^{+}\right)_{2}$.

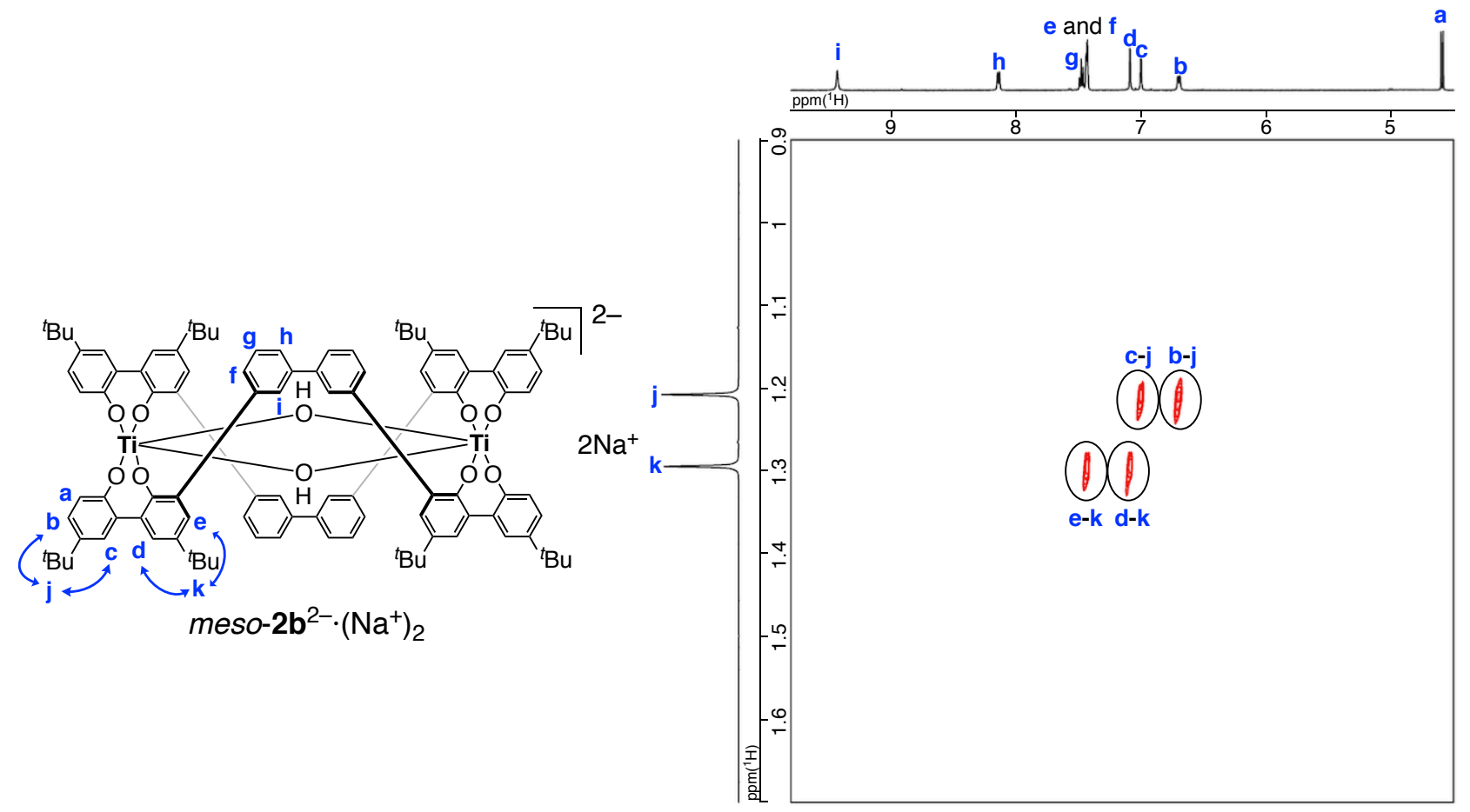

Figure S32. Partial NOESY spectrum of meso- $\mathbf{2 b}^{2-} \cdot\left(\mathrm{Na}^{+}\right)_{2}\left(500 \mathrm{MHz}, \mathrm{CD}_{3} \mathrm{CN}, 2.5 \mathrm{mM}, 25{ }^{\circ} \mathrm{C}\right.$, mixing time $=500 \mathrm{~ms}$ ). 

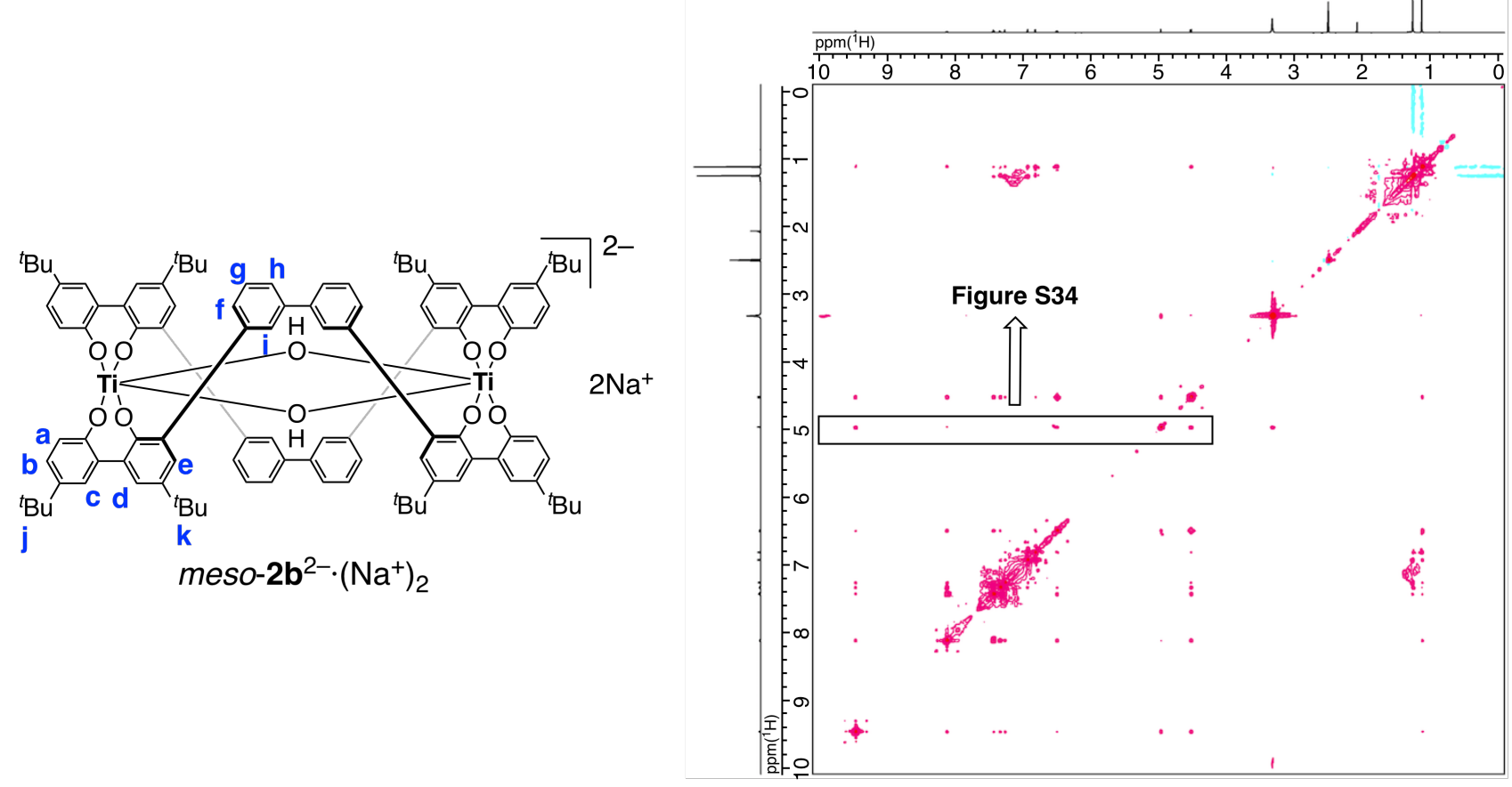

Figure S33. NOESY spectrum of meso-2 $\mathbf{b}^{2-} \cdot\left(\mathrm{Na}^{+}\right)_{2}\left(500 \mathrm{MHz}, \mathrm{DMSO}-d_{6}, 2.5 \mathrm{mM}, 25^{\circ} \mathrm{C}\right.$, mixing time $=500 \mathrm{~ms})$.


Figure S34. Partial NOESY spectrum of meso-2 $\mathbf{b}^{2-} \cdot\left(\mathrm{Na}^{+}\right)_{2}\left(500 \mathrm{MHz}, \mathrm{DMSO}-d_{6}, 2.5 \mathrm{mM}, 25{ }^{\circ} \mathrm{C}\right.$, mixing time $=500 \mathrm{~ms}$ ). Interstrand NOE cross-peaks are indicated by arrows in the crystal structure of meso-2 $\mathbf{b}^{2-} \cdot\left(\mathrm{Na}^{+}\right)_{2}$. 

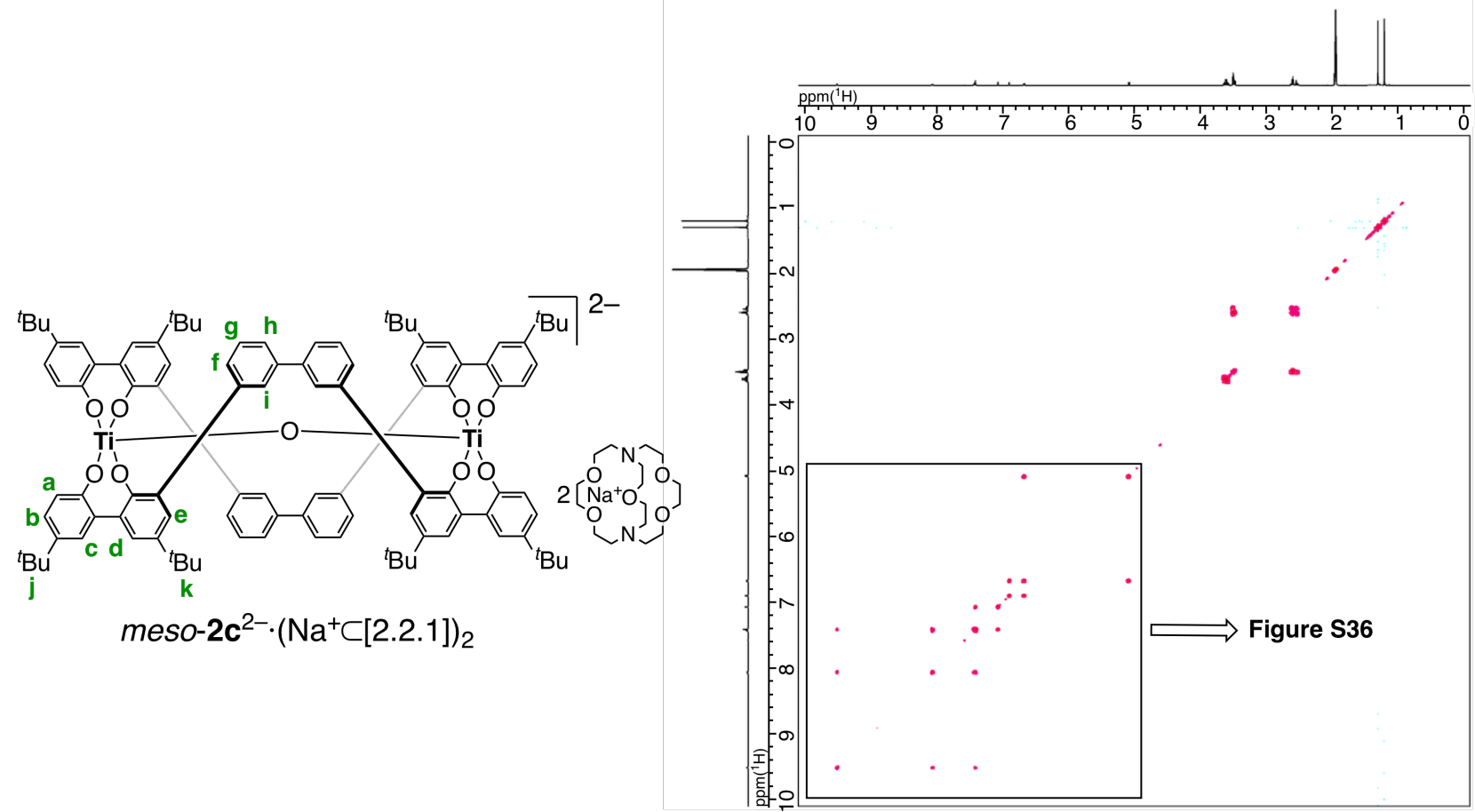

Figure S35. $g \mathrm{COSY}$ spectrum of meso-2 $\mathrm{c}^{2-} \cdot\left(\mathrm{Na}^{+} \subset[2.2 .1]\right)_{2}\left(500 \mathrm{MHz}, \mathrm{CD}_{3} \mathrm{CN}, 0.5 \mathrm{mM}, 25{ }^{\circ} \mathrm{C}\right)$.

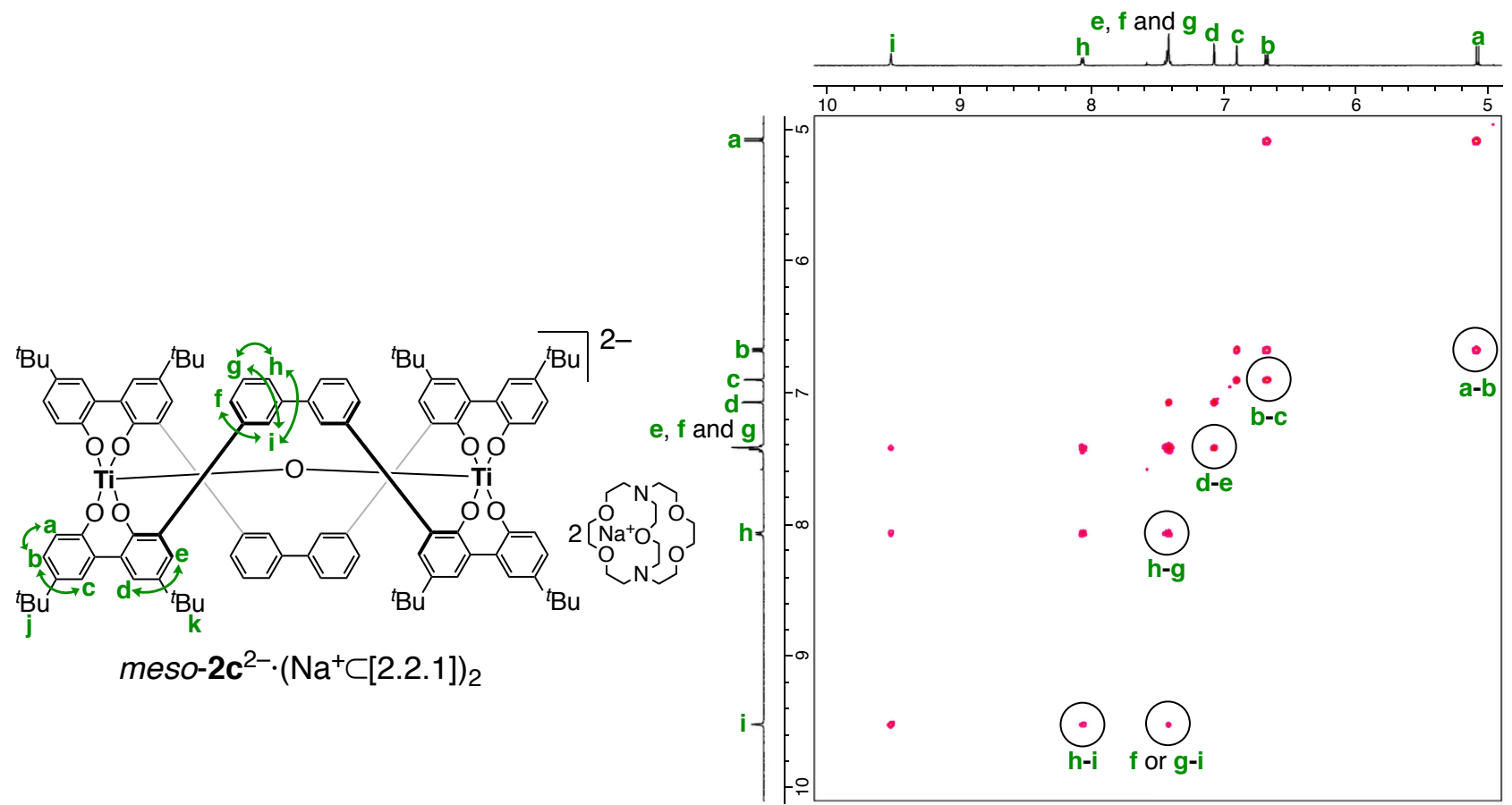

Figure S36. Partial gCOSY spectrum of meso-2 $\mathbf{c}^{2-} \cdot\left(\mathrm{Na}^{+} \subset[2.2 .1]\right)_{2}\left(500 \mathrm{MHz}, \mathrm{CD}_{3} \mathrm{CN}, 0.5 \mathrm{mM}\right.$, $\left.25^{\circ} \mathrm{C}\right)$. 




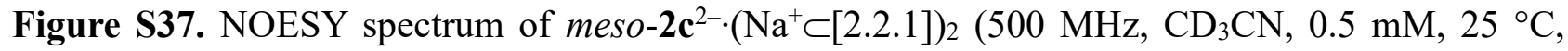
mixing time $=500 \mathrm{~ms}$ ). 


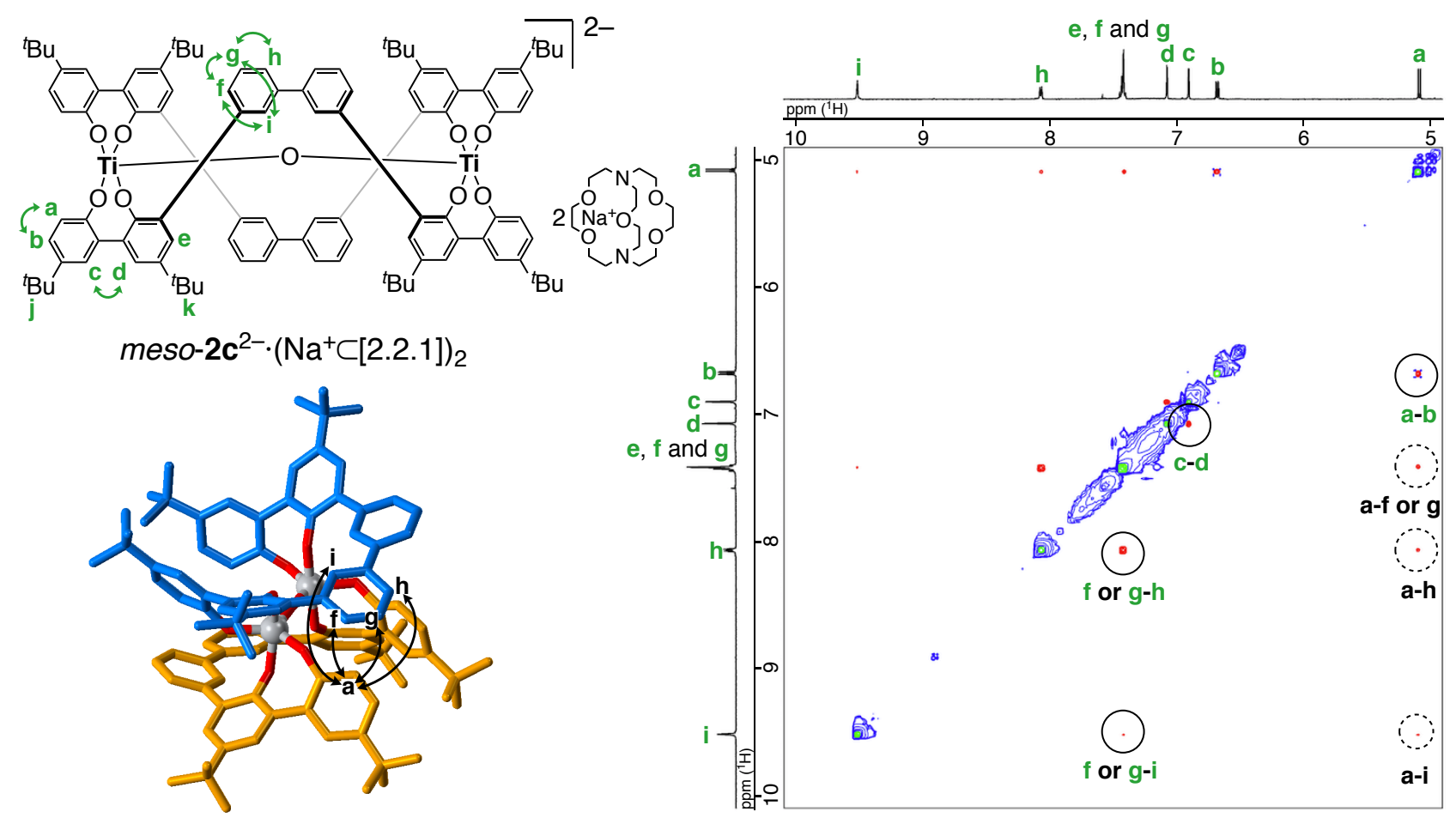

Figure S38. Partial NOESY spectrum of meso-2 $\mathbf{c}^{2-} \cdot\left(\mathrm{Na}^{+} \subset[2.2 .1]\right)_{2}\left(500 \mathrm{MHz}, \mathrm{CD}_{3} \mathrm{CN}, 0.5 \mathrm{mM}\right.$, $25^{\circ} \mathrm{C}$, mixing time $=500 \mathrm{~ms}$ ).

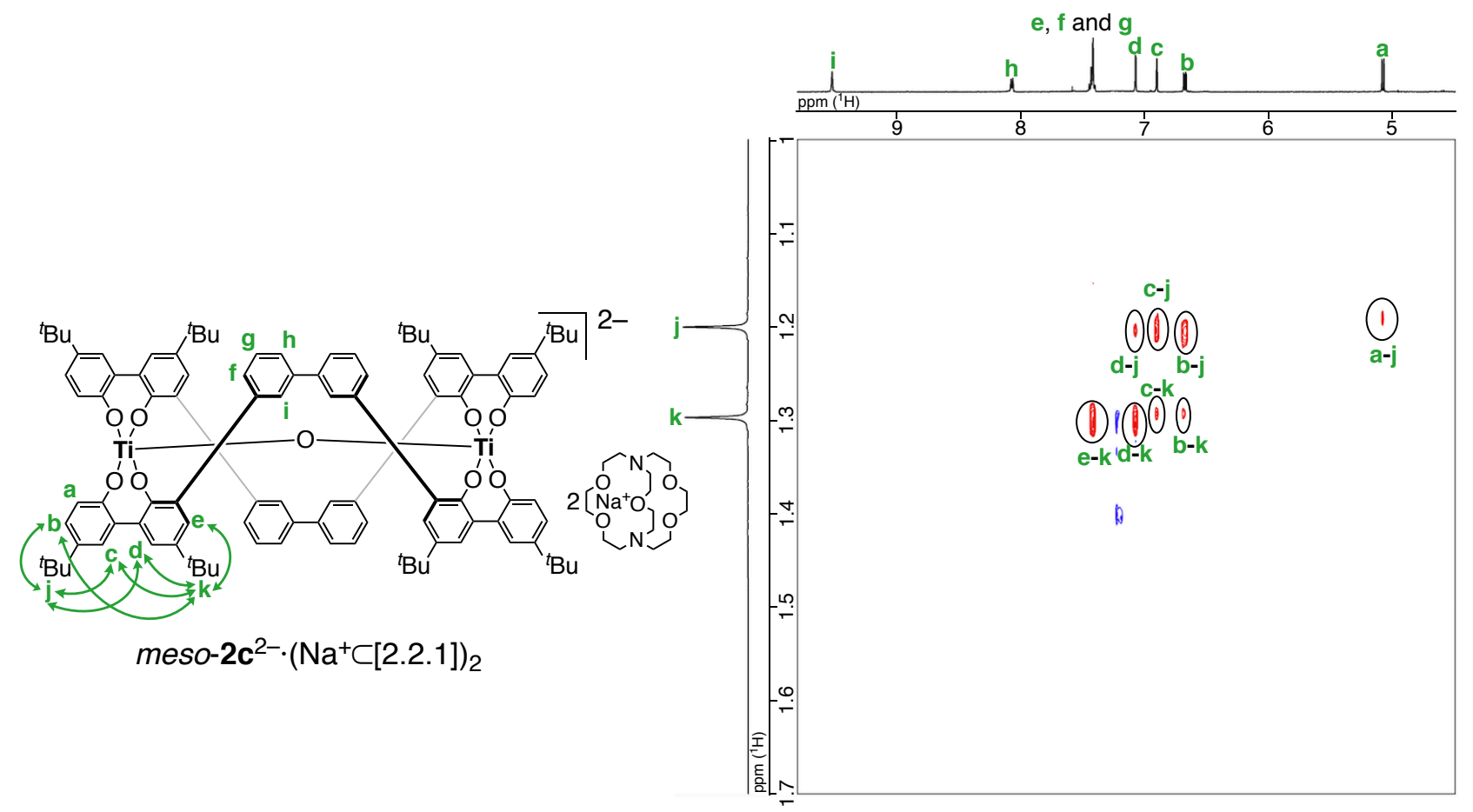

Figure S39. Partial NOESY spectrum of meso-2 $\mathbf{c}^{2-} \cdot\left(\mathrm{Na}^{+} \subset[2.2 .1]\right)_{2}\left(500 \mathrm{MHz}, \mathrm{CD}_{3} \mathrm{CN}, 0.5 \mathrm{mM}\right.$, $25^{\circ} \mathrm{C}$, mixing time $=500 \mathrm{~ms}$ ). 
(a) $\mathrm{rac}-2 \mathrm{a}^{2-} \cdot\left(\mathrm{Na}^{+}\right)_{2}$
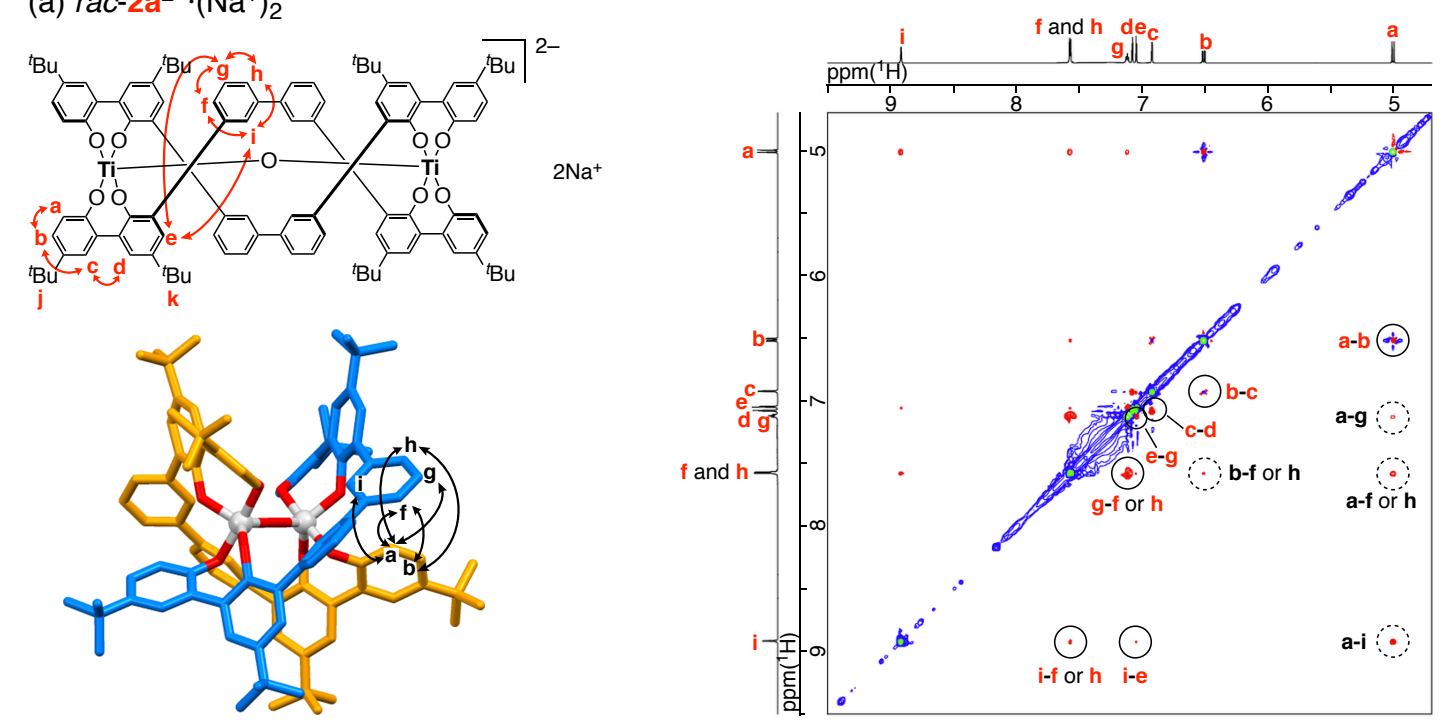

(b) $m e s o-2 b^{2-} \cdot\left(\mathrm{Na}^{+}\right)_{2}$
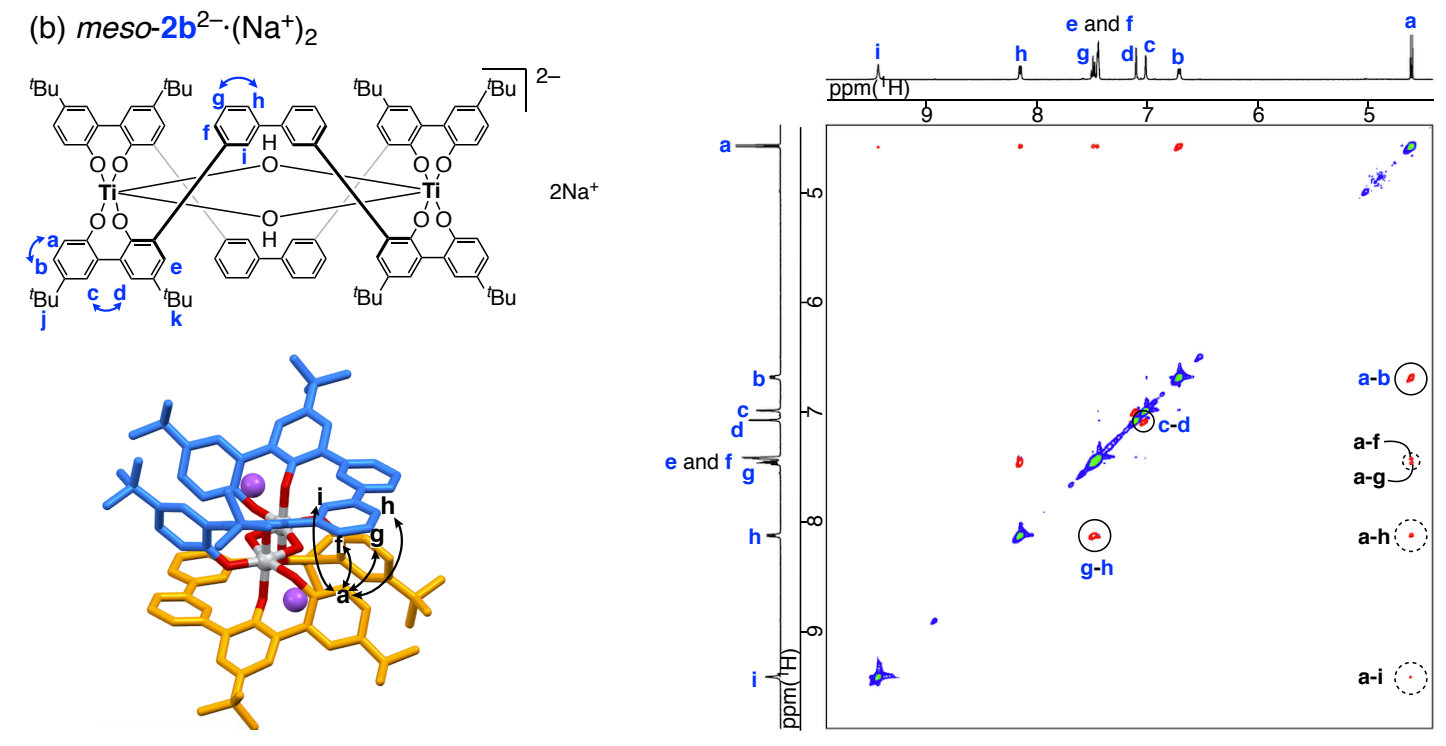

(c) $m e s o-2 c^{2-} \cdot\left(\mathrm{Na}^{+} \subset[2.2 .1]\right)_{2}$
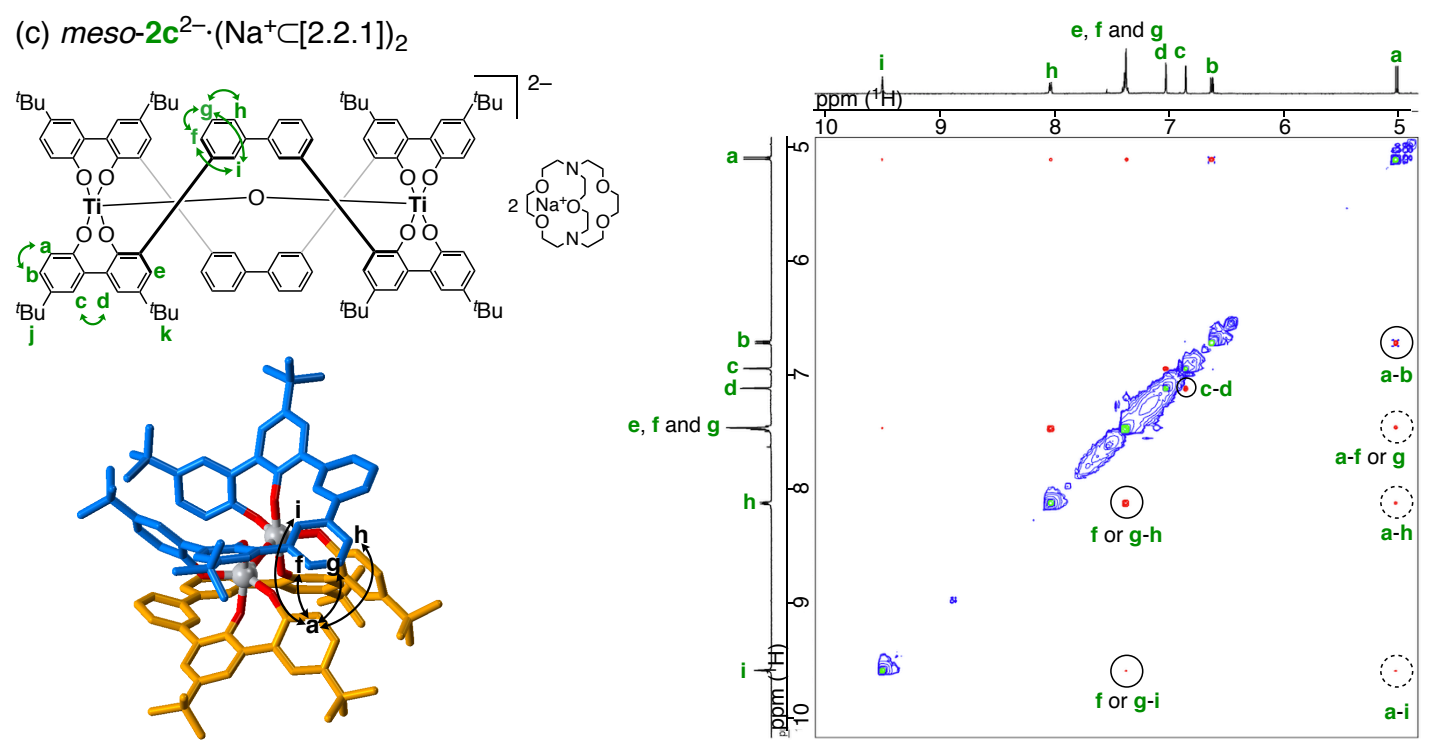

Figure S40. NOESY spectra of $r a c-2 \mathbf{a}^{2-} \cdot\left(\mathrm{Na}^{+}\right)_{2}(2.5 \mathrm{mM})(\mathrm{a}), \operatorname{meso}-\mathbf{2} \mathbf{b}^{2-} \cdot\left(\mathrm{Na}^{+}\right)_{2}(2.5 \mathrm{mM})(\mathrm{b})$, and meso-2c $\mathrm{c}^{2-} \cdot\left(\mathrm{Na}^{+} \subset[2.2 .1]\right)_{2}(0.5 \mathrm{mM})(\mathrm{c})\left(500 \mathrm{MHz}, \mathrm{CD}_{3} \mathrm{CN}, 25^{\circ} \mathrm{C}\right.$, mixing time $\left.=500 \mathrm{~ms}\right)$. 


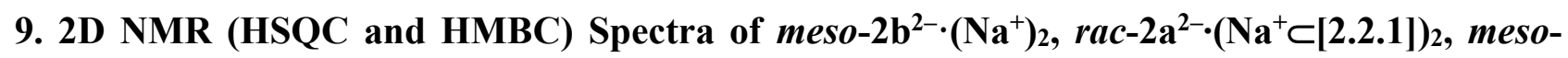
$2 \mathrm{~b}^{2-} \cdot\left(\mathrm{Na}^{+} \subset[2.2 .1]\right)_{2}$, and meso-2 $\mathrm{c}^{2-} \cdot\left(\mathrm{Na}^{+} \subset[2.2 .1]\right)_{2}$ and Their ${ }^{13} \mathrm{C}$ NMR Spectra with Peak Assignments.

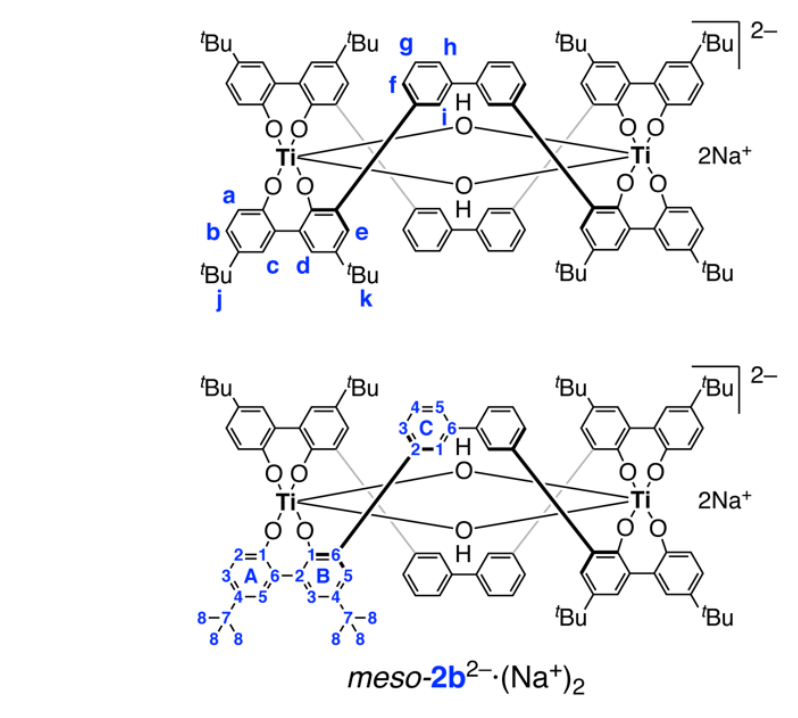

(a)
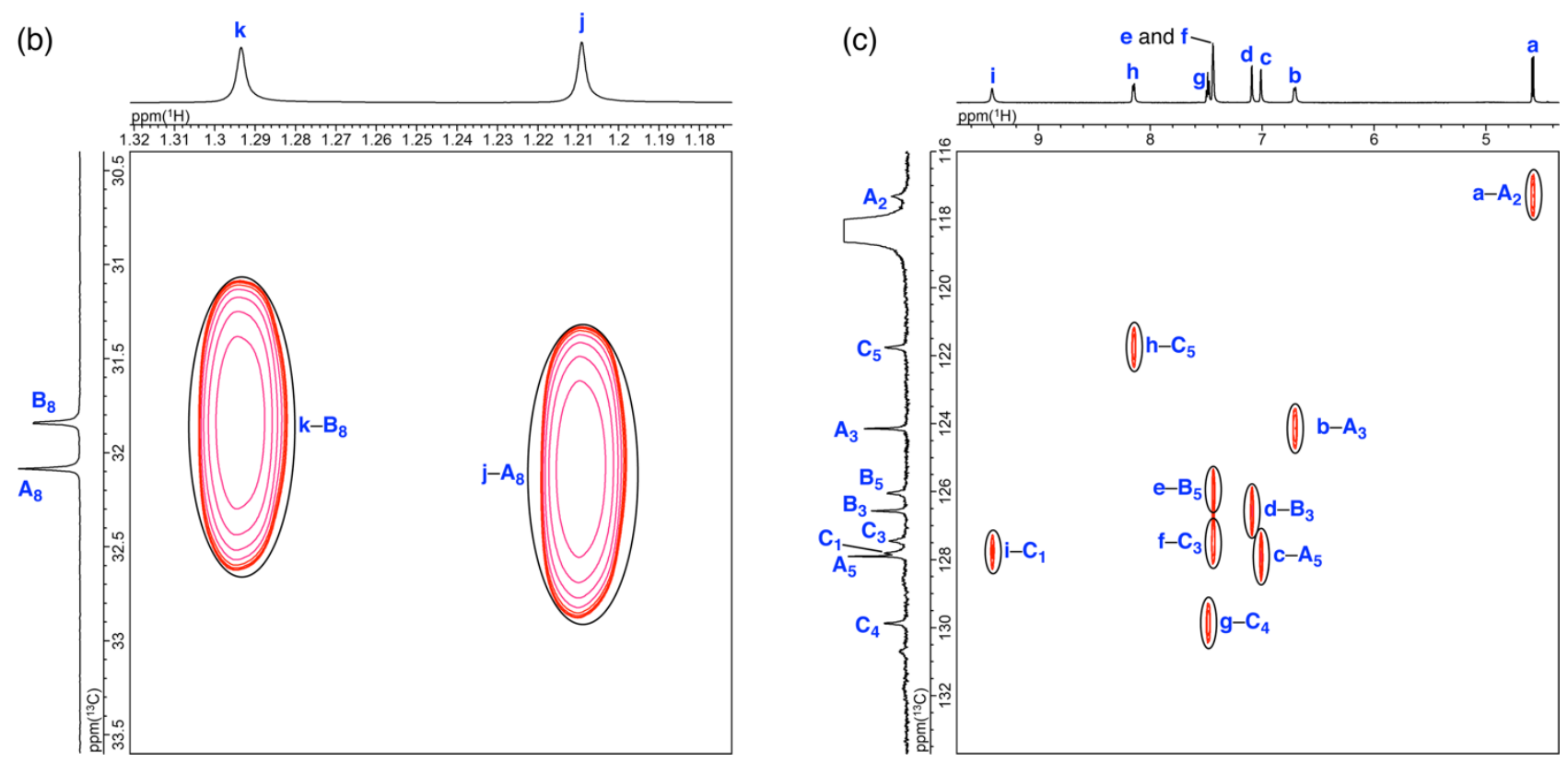

Figure S41. (a) Full and (b,c) partial HSQC spectra of meso-2 $\mathbf{b}^{2-} \cdot\left(\mathrm{Na}^{+}\right)_{2}\left(600 \mathrm{MHz}, \mathrm{CD}_{3} \mathrm{CN}, 2.0 \mathrm{mM}\right.$, $\left.27^{\circ} \mathrm{C}\right)$. 
(a)


Figure S42. (a) Full and (b-e) partial HMBC spectra of meso-2 $\mathbf{b}^{2-} \cdot\left(\mathrm{Na}^{+}\right)_{2}\left(600 \mathrm{MHz}, \mathrm{CD}_{3} \mathrm{CN}, 2.0\right.$ $\left.\mathrm{mM}, 27^{\circ} \mathrm{C}\right)$. 

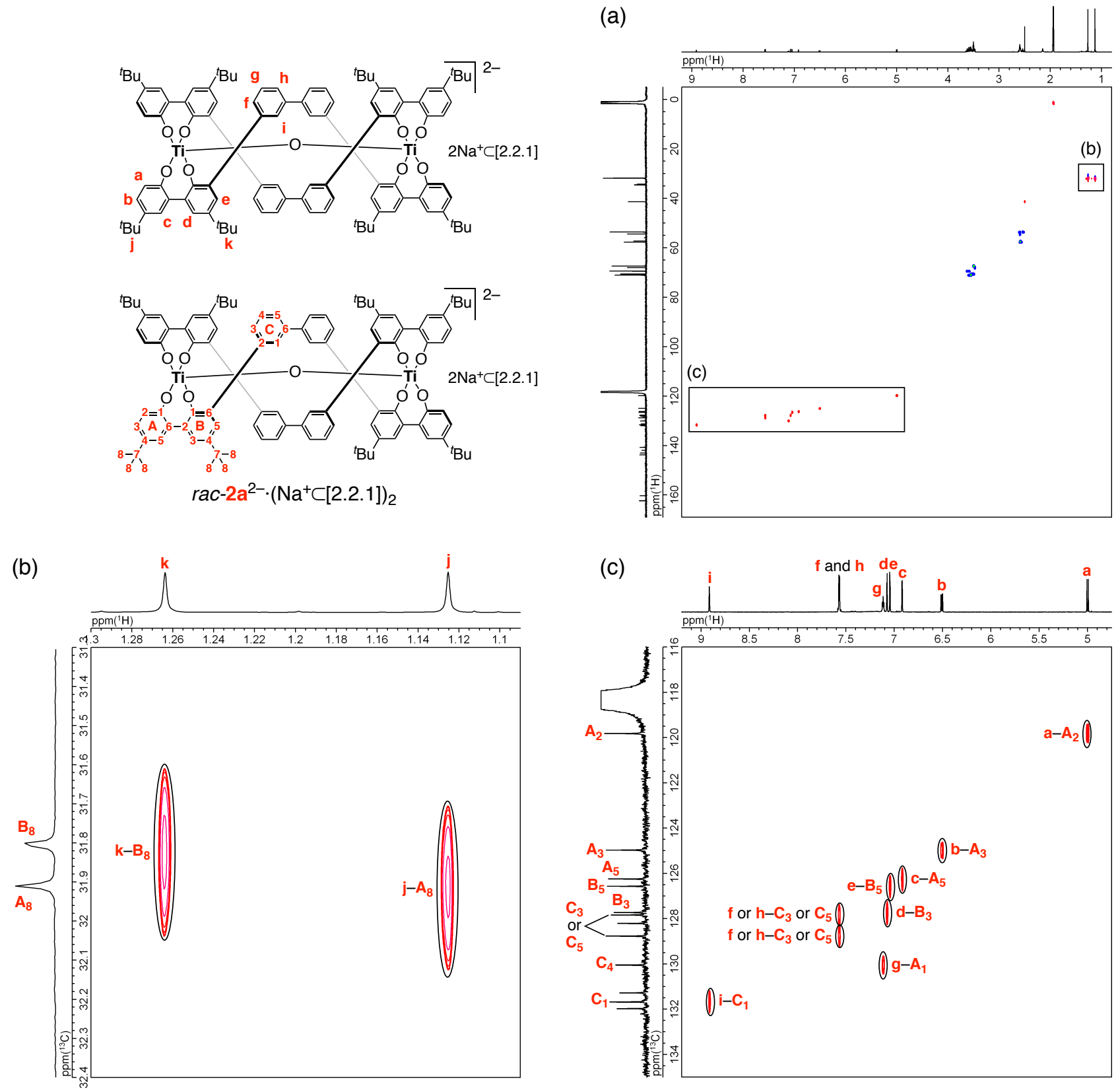

Figure S43. (a) Full and (b,c) partial HSQC spectra of $r a c-\mathbf{2 a}^{2-} \cdot\left(\mathrm{Na}^{+}\right)_{2}\left(600 \mathrm{MHz}, \mathrm{CD}_{3} \mathrm{CN}, 0.5 \mathrm{mM}\right.$, rt) in the presence of 4 equiv of cryptand[2.2.1]. 

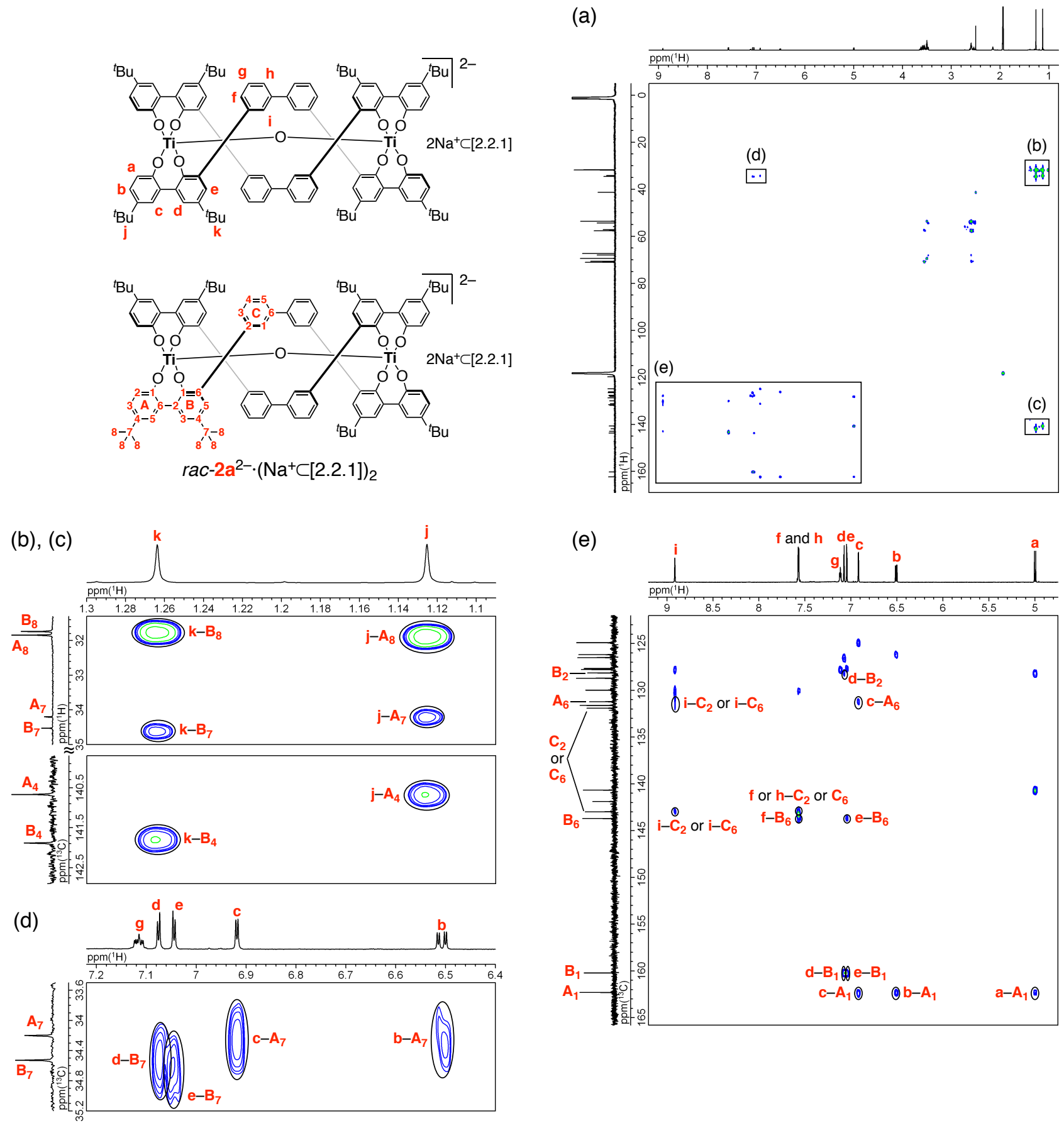

Figure S44. (a) Full and (b-e) partial HMBC spectra of $r a c-2 \mathbf{a}^{2-} \cdot\left(\mathrm{Na}^{+}\right)_{2}\left(600 \mathrm{MHz}, \mathrm{CD}_{3} \mathrm{CN}, 0.5 \mathrm{mM}\right.$, $\mathrm{rt}$ ) in the presence of 4 equiv of cryptand[2.2.1]. 

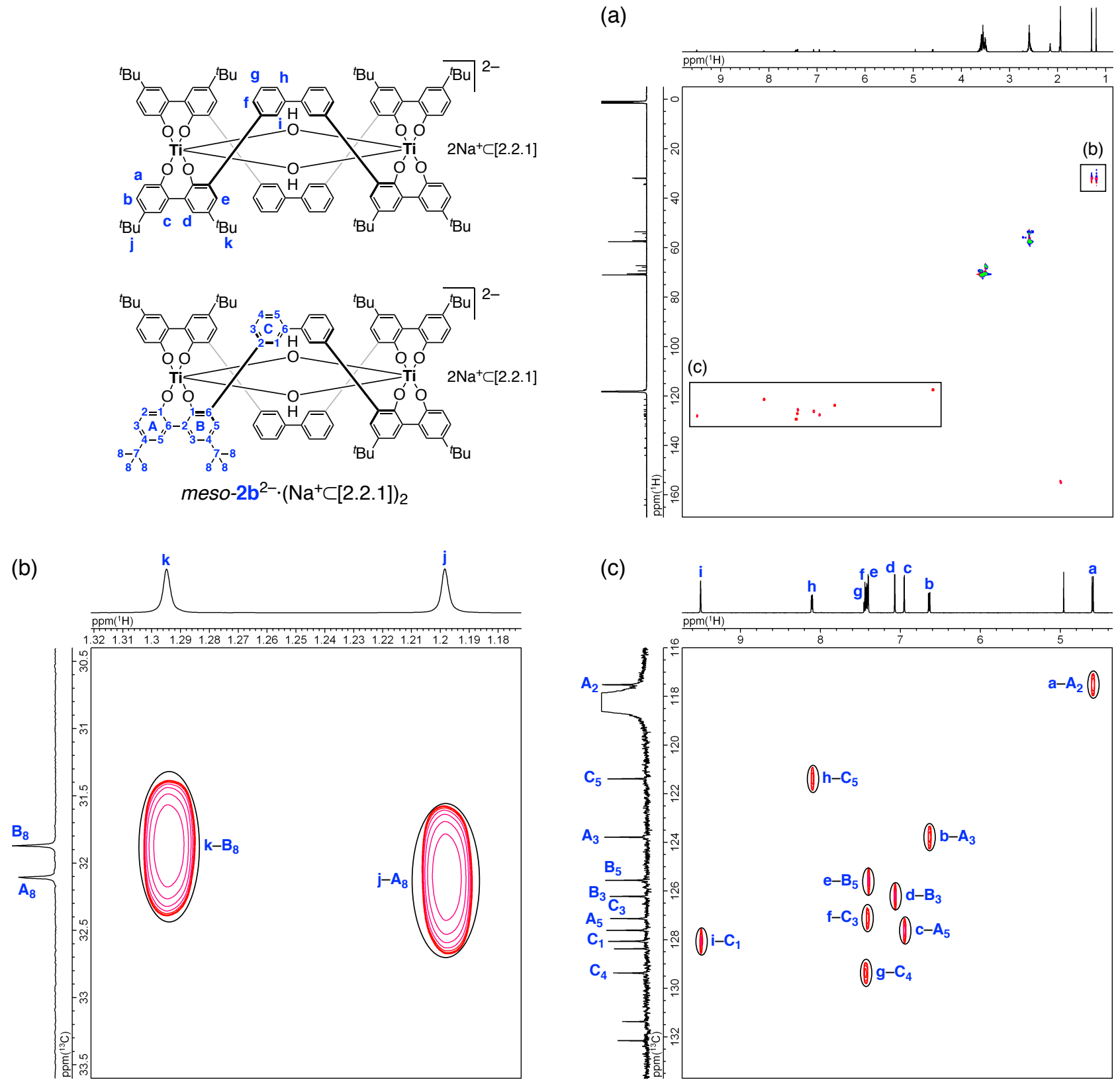

Figure S45. (a) Full and (b,c) partial HSQC spectra of meso-2 $\mathbf{b}^{2-} \cdot\left(\mathrm{Na}^{+}\right)_{2}(600 \mathrm{MHz}, \mathrm{CD} 3 \mathrm{CN}, 2.0 \mathrm{mM}$, $\mathrm{rt}$ ) in the presence of 4 equiv of cryptand[2.2.1]. 
(a)
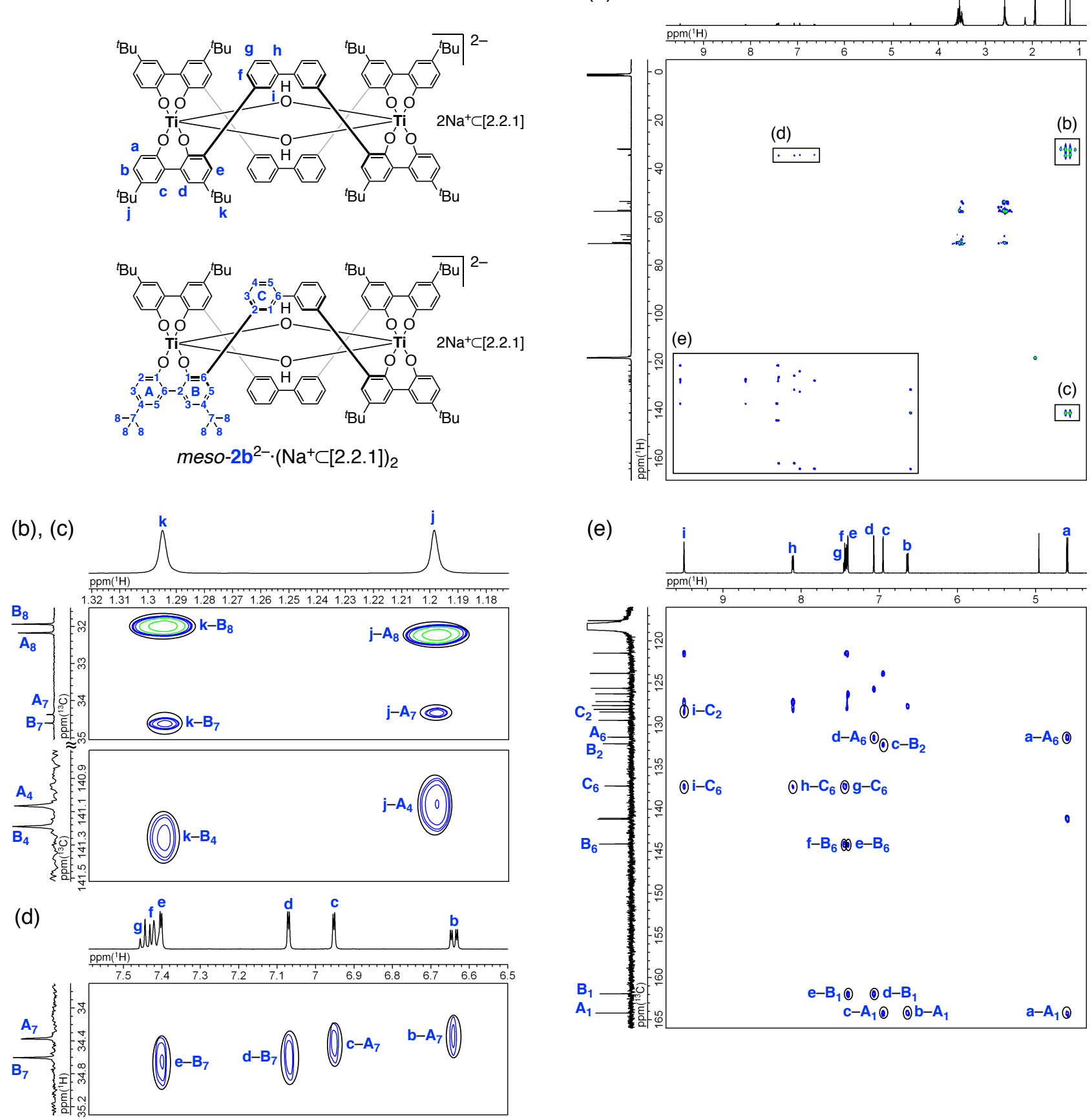

Figure S46. (a) Full and (b-e) partial HMBC spectra of $m e s o-\mathbf{2 b}^{2-} \cdot\left(\mathrm{Na}^{+}\right)_{2}\left(600 \mathrm{MHz}, \mathrm{CD}_{3} \mathrm{CN}, 2.0\right.$ $\mathrm{mM}, \mathrm{rt})$ in the presence of 4 equiv of cryptand[2.2.1]. 

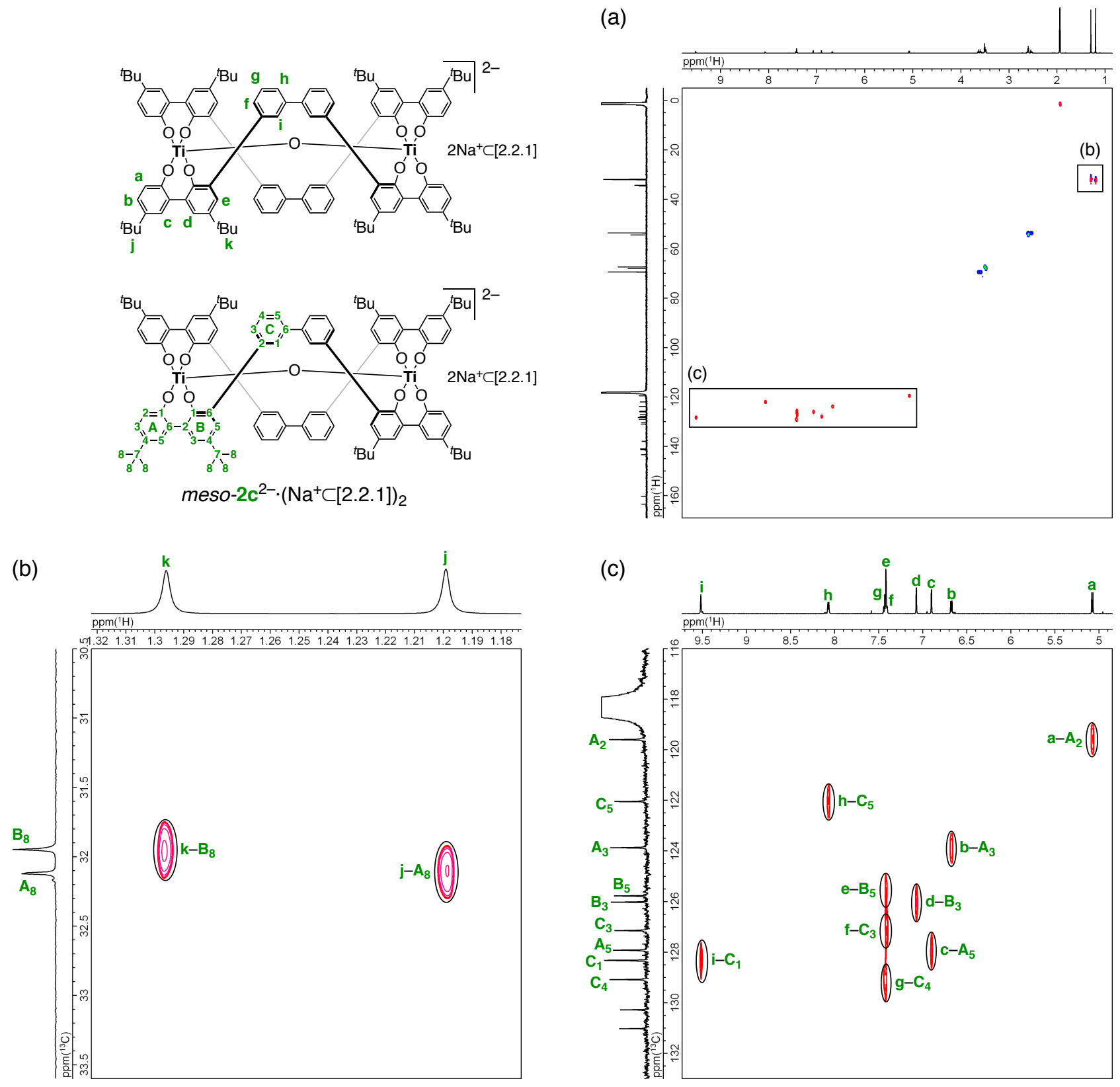

Figure S47. (a) Full and (b,c) partial HSQC spectra of meso-2c ${ }^{2-} \cdot\left(\mathrm{Na}^{+} \subset[2.2 .1]\right)_{2}\left(600 \mathrm{MHz}, \mathrm{CD}_{3} \mathrm{CN}\right.$, $0.5 \mathrm{mM}, \mathrm{rt})$ in the presence of 4 equiv of cryptand[2.2.1]. 
(a)
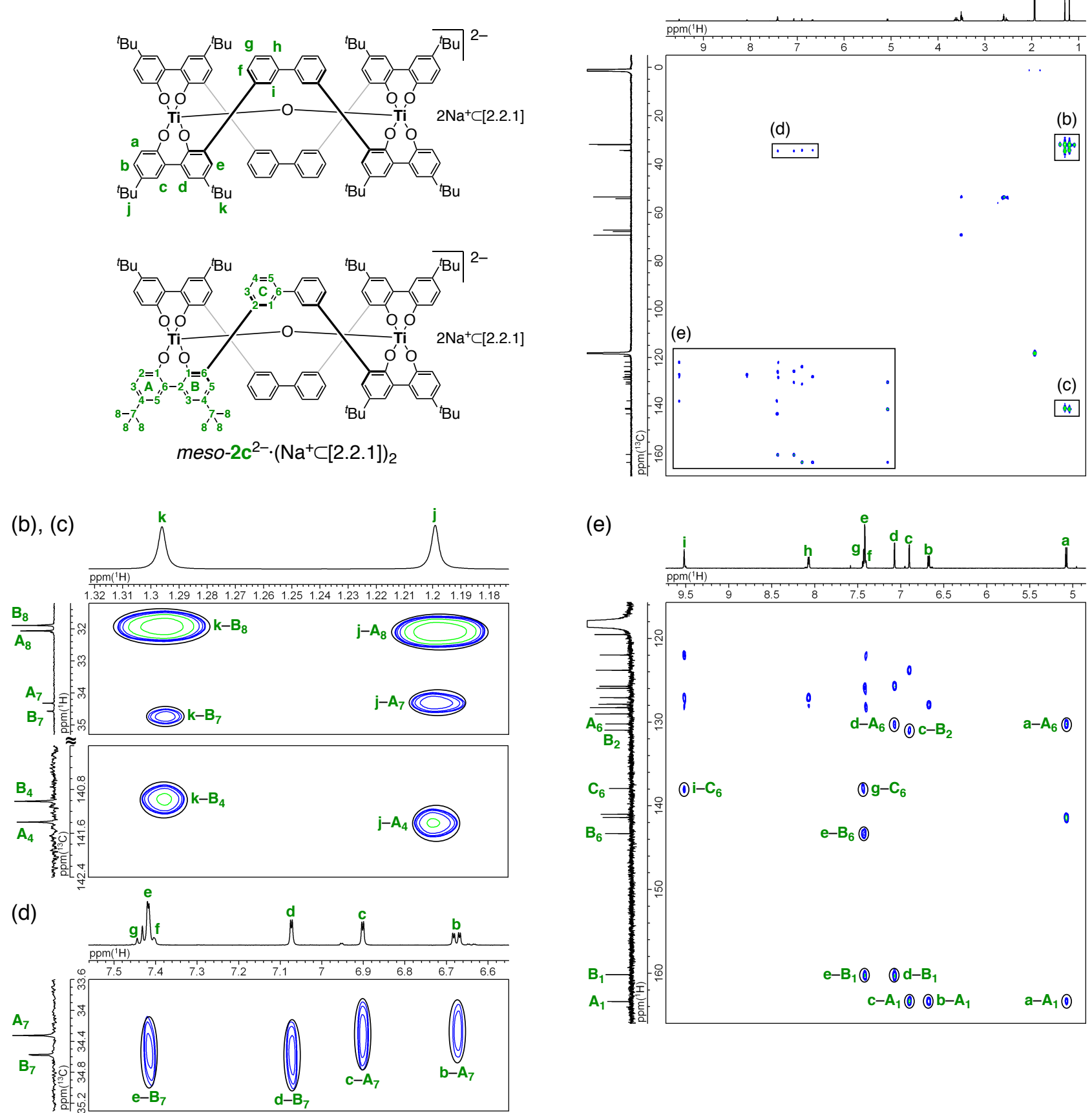

Figure S48. (a) Full and (b-e) partial HMBC spectra of $m e s o-2 c^{2-} \cdot\left(\mathrm{Na}^{+} \subset[2.2 .1]\right)_{2}\left(600 \mathrm{MHz}, \mathrm{CD}_{3} \mathrm{CN}\right.$, $0.5 \mathrm{mM}, \mathrm{rt}$ ) in the presence of 4 equiv of cryptand[2.2.1]. 
10. Racemization of $2 \mathrm{a}^{2-}$ during the Resolution of $\mathrm{rac}-2 \mathrm{a}^{2-} \cdot\left(\mathrm{Na}^{+}\right)_{2}$ with Optically Active Ammonium Salts.

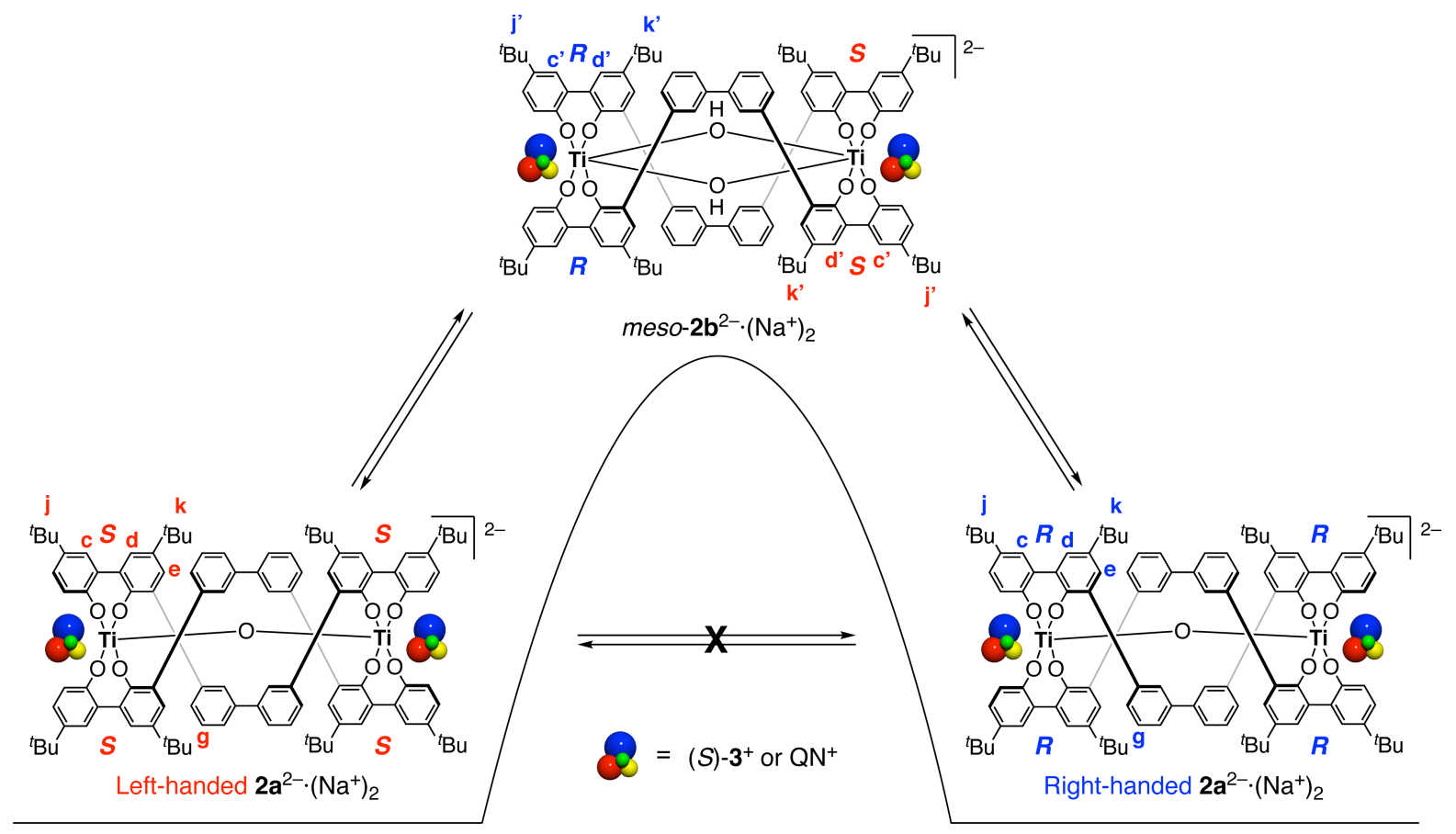

Figure S49. Plausible mechanism for racemization of $2 \mathbf{a}^{2-} \cdot\left(\mathrm{Na}^{+}\right)_{2}$ in the presence of optically active $(S)-3^{+} \cdot \mathrm{I}^{-}$and $N$-benzylquininium chloride $\left(\mathrm{QN}^{+} \cdot \mathrm{Cl}^{-}\right)$.

\section{Transformation from meso-2 $\mathrm{b}^{2-} \cdot\left(\mathrm{Na}^{+}\right)_{2}$ to $\mathrm{rac}-2 \mathrm{a}^{2-} \cdot\left(\mathrm{Na}^{+}\right)_{2}$ in the Presence of Chiral Additives.}
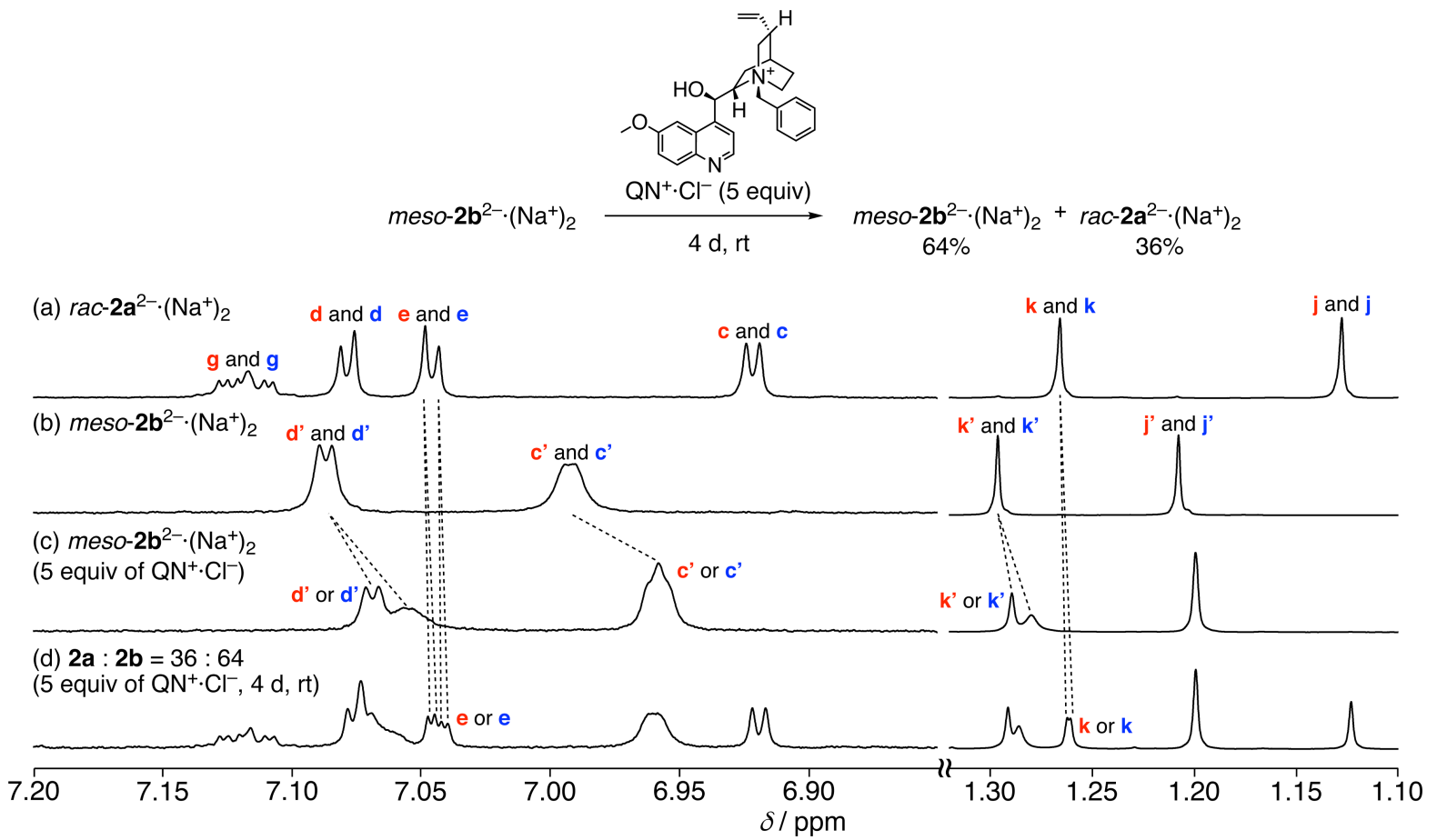

Figure S50. Partial ${ }^{1} \mathrm{H}$ NMR spectra of $r a c-2 \mathbf{a}^{2-} \cdot\left(\mathrm{Na}^{+}\right)_{2}$ (a) and $m e s o-\mathbf{b}^{2-} \cdot\left(\mathrm{Na}^{+}\right)_{2}$ (b) (500 MHz, $\mathrm{CD}_{3} \mathrm{CN}$ containing $\mathrm{H}_{2} \mathrm{O}\left(\left[\mathrm{H}_{2} \mathrm{O}\right]_{0} /\left[\text { meso-2 } \mathbf{b}^{2-} \cdot\left(\mathrm{Na}^{+}\right)_{2}\right]_{0}=\right.$ ca. 64$\left.), 0.5 \mathrm{mM}, 25{ }^{\circ} \mathrm{C}\right)$ in the presence of 5 equiv of $\mathrm{QN}^{+} \cdot \mathrm{Cl}^{-}$before (c) and after (d) standing the sample at room temperature for 4 days. 


\section{Supporting References}

(S1) Miwa, K.; Furusho, Y.; Yashima, E., Nat. Chem. 2010, 2, 444-449.

(S2) CrystalClear, Version 1.36; Molecular Structure Corporation: The Woodlands, TX, 2000 and Rigaku Corporation: Tokyo, Japan.

(S3) Burla, M. C.; Caliandro, R.; Camalli, M.; Carrozzini, B.; Cascarano, G. L.; Caro, L. D.; Giacovazzo, C.; Polidori, G.; Spagna, R. J. Appl. Crystallogr. 2005, 38, 381-388.

(S4) Sheldrick, G. M. SHELXL-97: Program for the Refinement of Crystal Structures; University of Göttingen, Göttingen, Germany, 1997.

(S5) Sheldrick, G. M. Acta Crystallogr. 2008, A64, 112-122.

(S6) (a) Wakita, K. Yadokari-XG, Program for Crystal Structure Analysis; 2000. (b) Kabuto, C.; Akine, S.; Kwon, E. J. Cryst. Soc. Jpn. 2009, 51, 218-224.

(S7) Thompson, M. ArgusLab, Planaria Software LLC, Seattle, WA (1996).

(S8) Grimme, S.; Antony, J.; Ehrlich, S.; Krieg, H. J. Chem. Phys. 2010, 132, 154104.

(S9) Gaussian 16, Revision A.03, Frisch, M. J.; Trucks, G. W.; Schlegel, H. B.; Scuseria, G. E.; Robb, M. A.; Cheeseman, J. R.; Scalmani, G.; Barone, V.; Petersson, G. A.; Nakatsuji, H.; Li, X.; Caricato, M.; Marenich, A. V.; Bloino, J.; Janesko, B. G.; Gomperts, R.; Mennucci, B.; Hratchian, H. P.; Ortiz, J. V.; Izmaylov, A. F.; Sonnenberg, J. L.; Williams-Young, D.; Ding, F.; Lipparini, F.; Egidi, F.; Goings, J.; Peng, B.; Petrone, A.; Henderson, T.; Ranasinghe, D.; Zakrzewski, V. G.; Gao, J.; Rega, N.; Zheng, G.; Liang, W.; Hada, M.; Ehara, M.; Toyota, K.; Fukuda, R.; Hasegawa, J.; Ishida, M.; Nakajima, T.; Honda, Y.; Kitao, O.; Nakai, H.; Vreven, T.; Throssell, K.; Montgomery, J. A., Jr.; Peralta, J. E.; Ogliaro, F.; Bearpark, M. J.; Heyd, J. J.; Brothers, E. N.; Kudin, K. N.; Staroverov, V. N.; Keith, T. A.; Kobayashi, R.; Normand, J.; Raghavachari, K.; Rendell, A. P.; Burant, J. C.; Iyengar, S. S.; Tomasi, J.; Cossi, M.; Millam, J. M.; Klene, M.; Adamo, C.; Cammi, R.; Ochterski, J. W.; Martin, R. L.; Morokuma, K.; Farkas, O.; Foresman, J. B.; Fox, D. J. Gaussian, Inc., Wallingford CT, 2016.

(S10) J. J. P. Stewart, J. Mol. Model. 2007, 13, 1173-1213.

(S11) J. J. P. Stewart, MOPAC2012, Stewart Computational Chemistry, Colorado Springs, CO, USA, http://openmopac.net/2012. 


\section{Supporting Data}

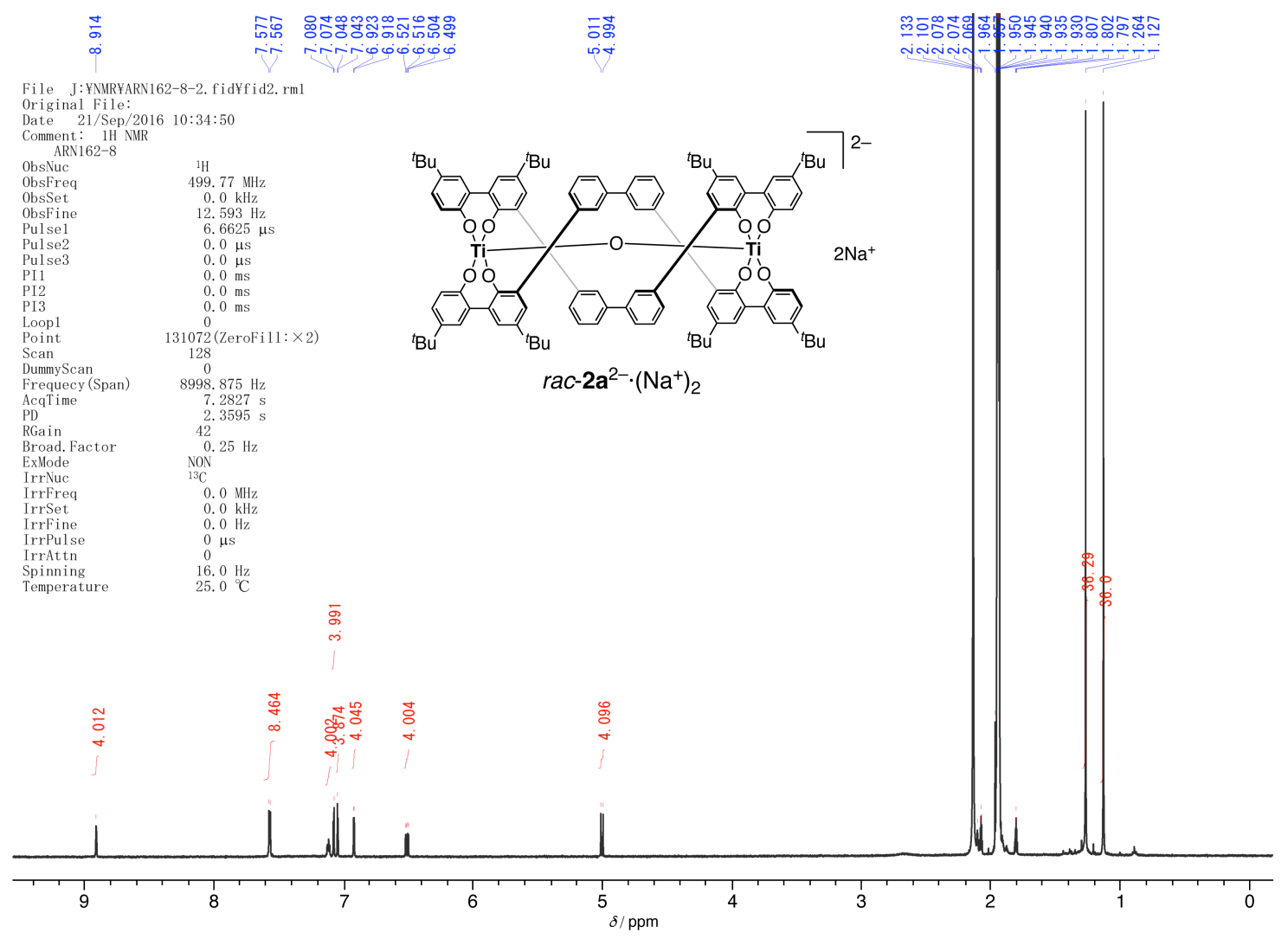

Figure S51. ${ }^{1} \mathrm{H}$ NMR spectrum of $r a c-2 a^{2-} \cdot\left(\mathrm{Na}^{+}\right)_{2}$ in $\mathrm{CD}_{3} \mathrm{CN}$ at $25^{\circ} \mathrm{C}$.

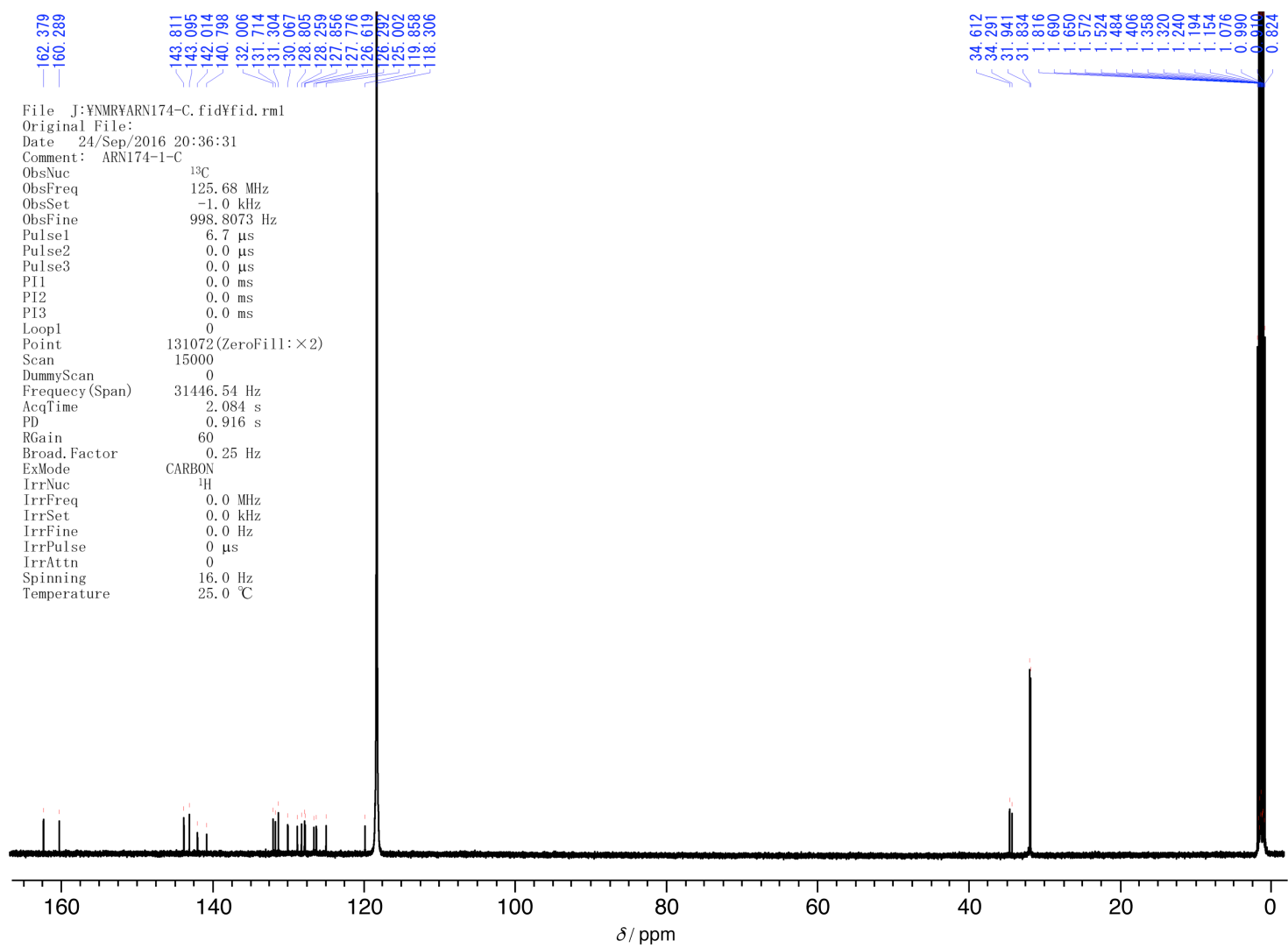

Figure S52. ${ }^{13} \mathrm{C}$ NMR spectrum of $r a c-2 a^{2-} \cdot\left(\mathrm{Na}^{+}\right)_{2}$ in $\mathrm{CD}_{3} \mathrm{CN}$ at $25{ }^{\circ} \mathrm{C}$. 


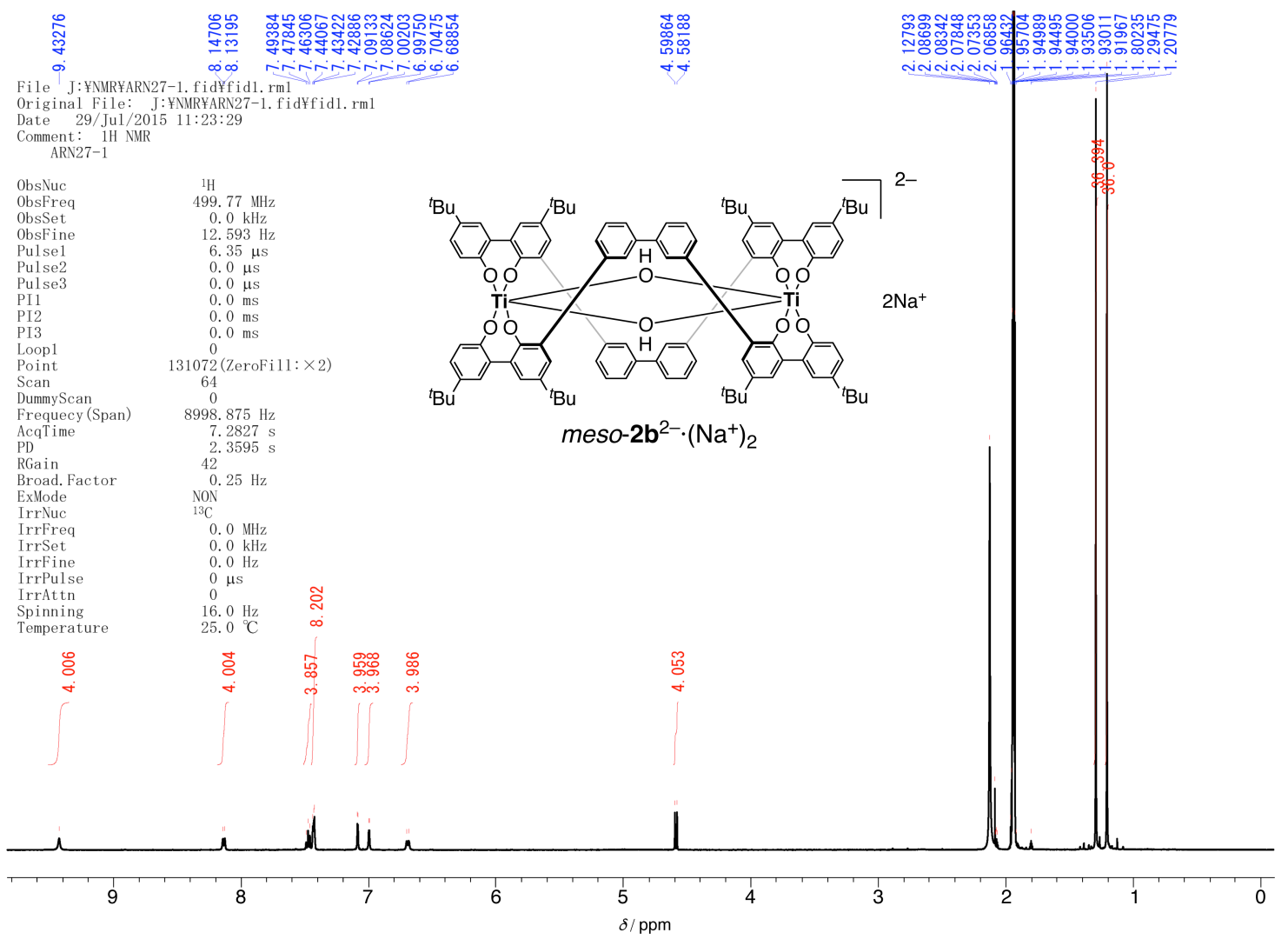

Figure S53. ${ }^{1} \mathrm{H}$ NMR spectrum of meso-2 $\mathbf{b}^{2-} \cdot\left(\mathrm{Na}^{+}\right)_{2}$ in $\mathrm{CD}_{3} \mathrm{CN}$ at $25{ }^{\circ} \mathrm{C}$.



Figure S54. ${ }^{13} \mathrm{C}$ NMR spectrum of meso-2 $\mathbf{b}^{2-} \cdot\left(\mathrm{Na}^{+}\right)_{2}$ in $\mathrm{CD}_{3} \mathrm{CN}$ at $30{ }^{\circ} \mathrm{C}$. 


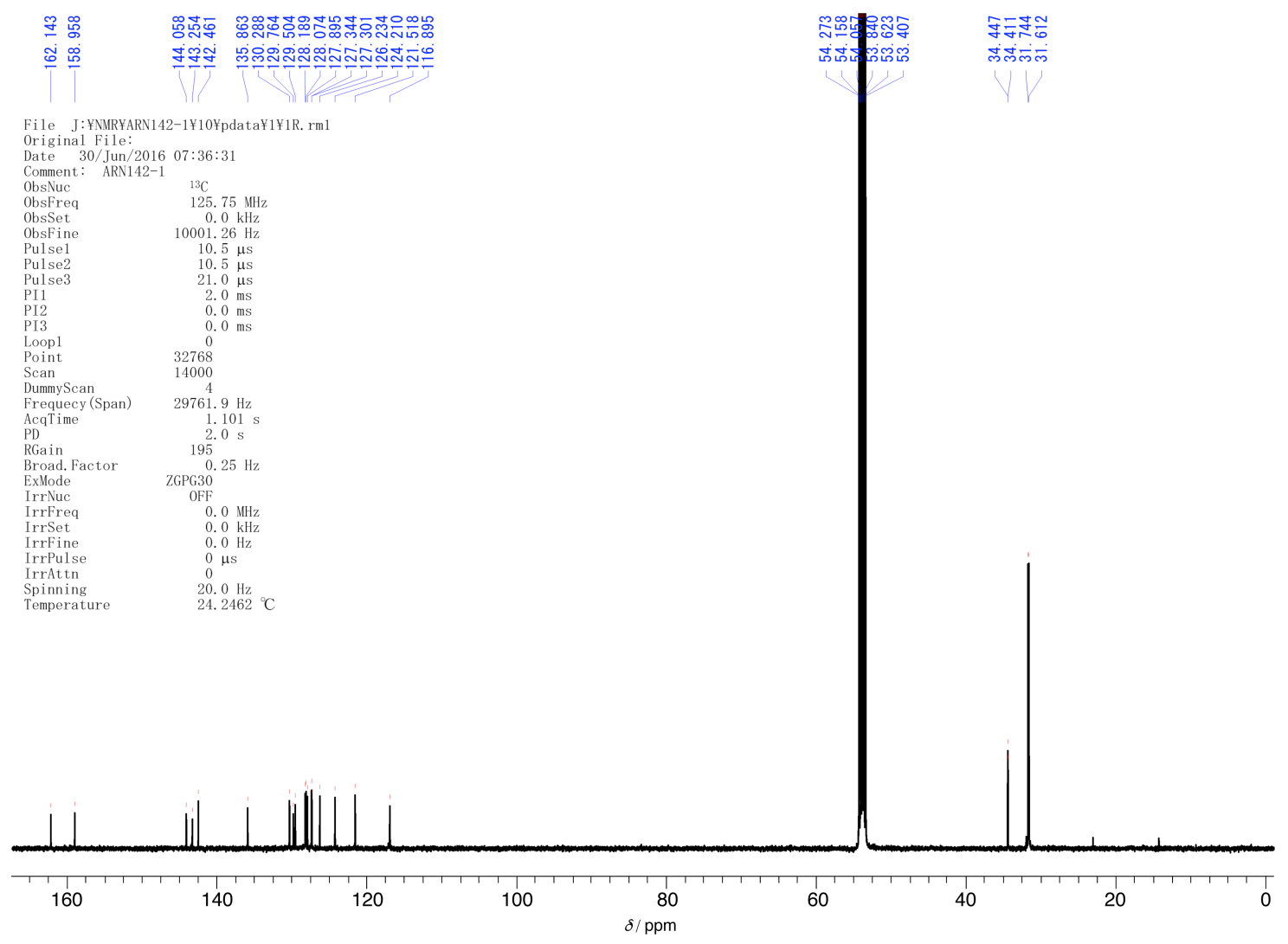

Figure S55. ${ }^{13} \mathrm{C}$ NMR spectrum of meso-2 $\mathbf{b}^{2-} \cdot\left(\mathrm{Na}^{+}\right)_{2}$ in $\mathrm{CD}_{2} \mathrm{Cl}_{2}$ at $24{ }^{\circ} \mathrm{C}$. 


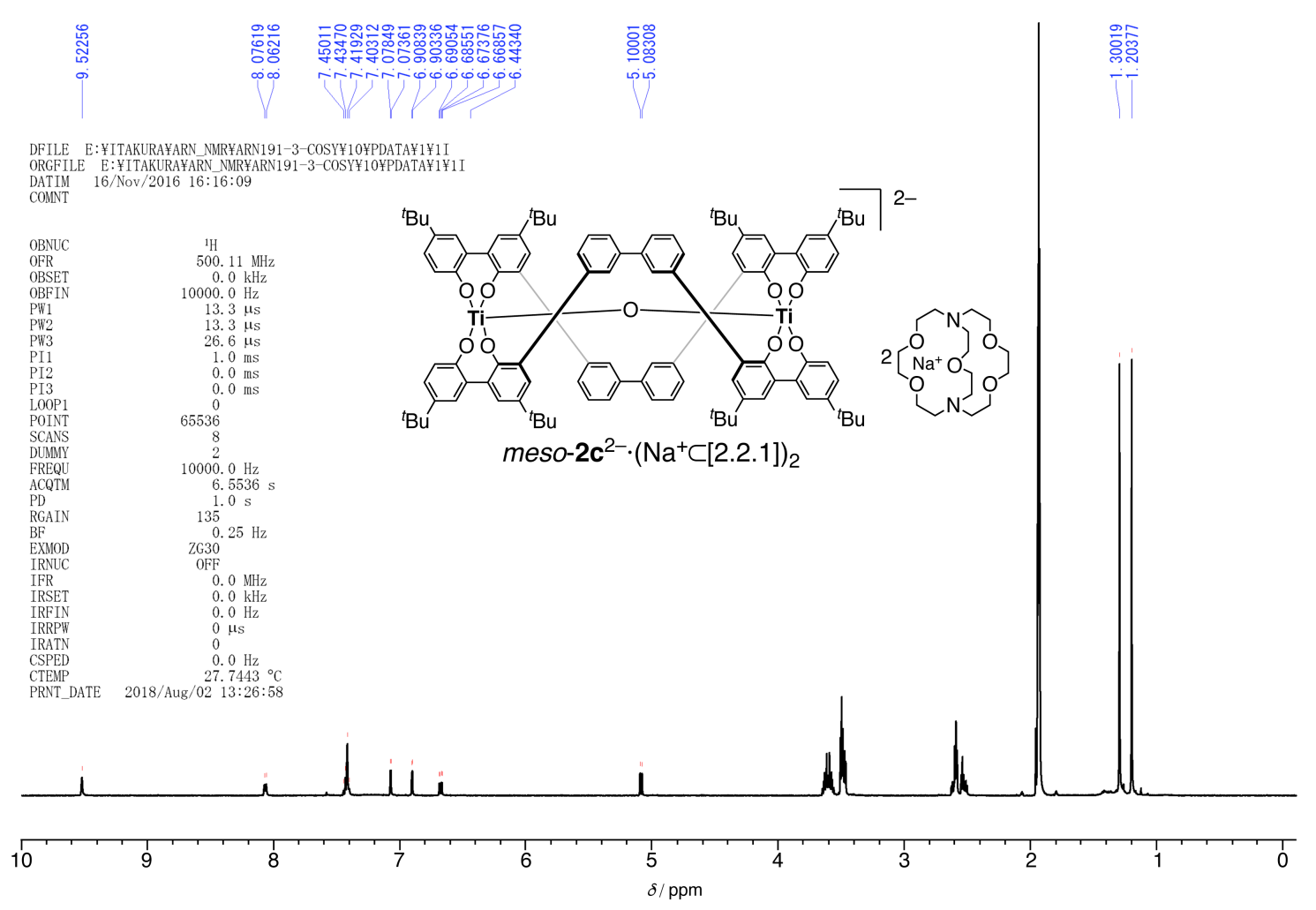

Figure S56. ${ }^{1} \mathrm{H}$ NMR spectrum of meso-2 $\mathrm{c}^{2-} \cdot\left(\mathrm{Na}^{+} \subset[2.2 .1]\right)_{2}$ in $\mathrm{CD}_{3} \mathrm{CN}$ at $28^{\circ} \mathrm{C}$.

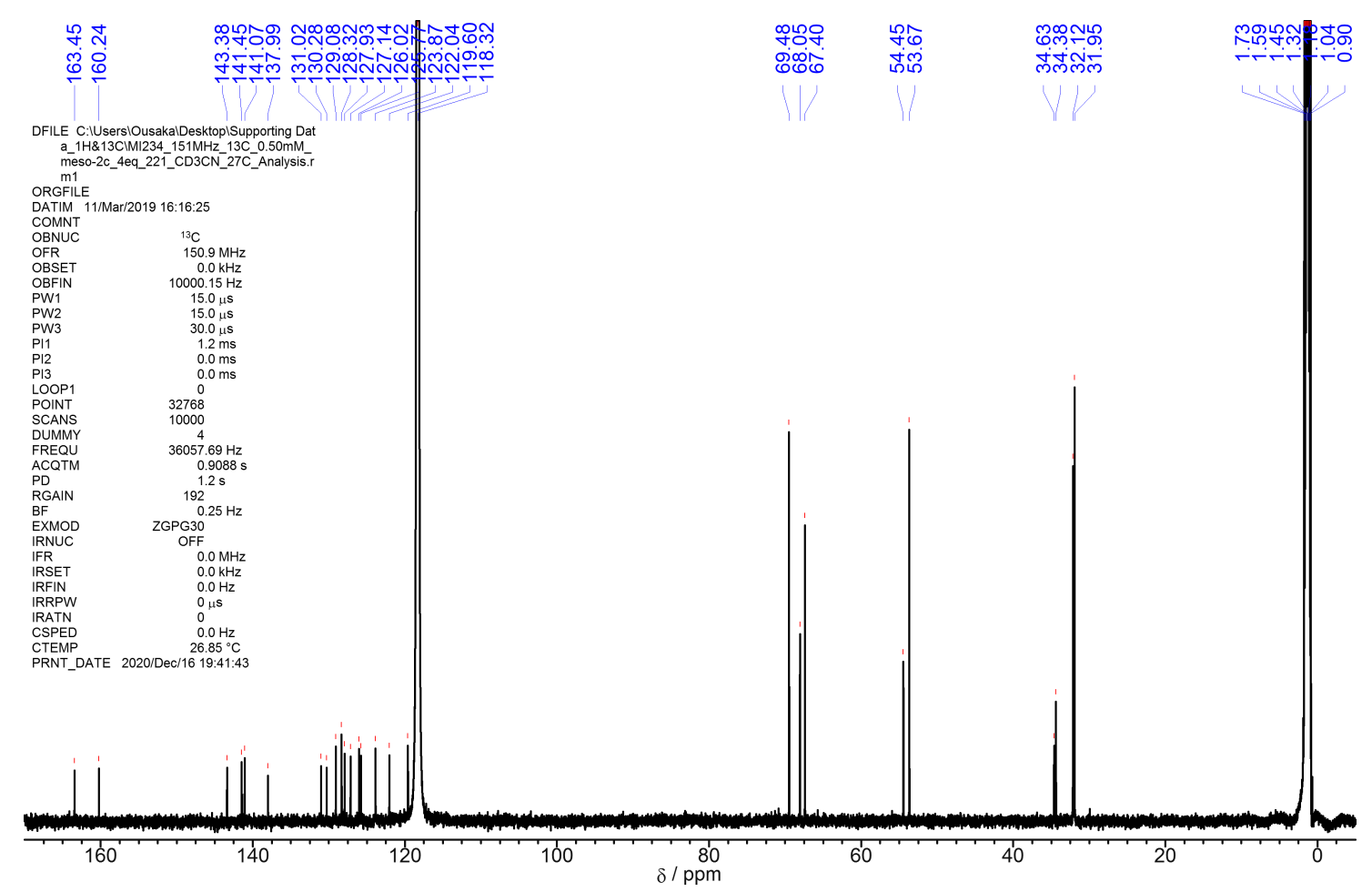

Figure S57. ${ }^{13} \mathrm{C}$ NMR spectrum of meso-2 $\mathbf{c}^{2-} \cdot\left(\mathrm{Na}^{+} \subset[2.2 .1]\right)_{2}$ in $\mathrm{CD}_{3} \mathrm{CN}$ at $27{ }^{\circ} \mathrm{C}$. 


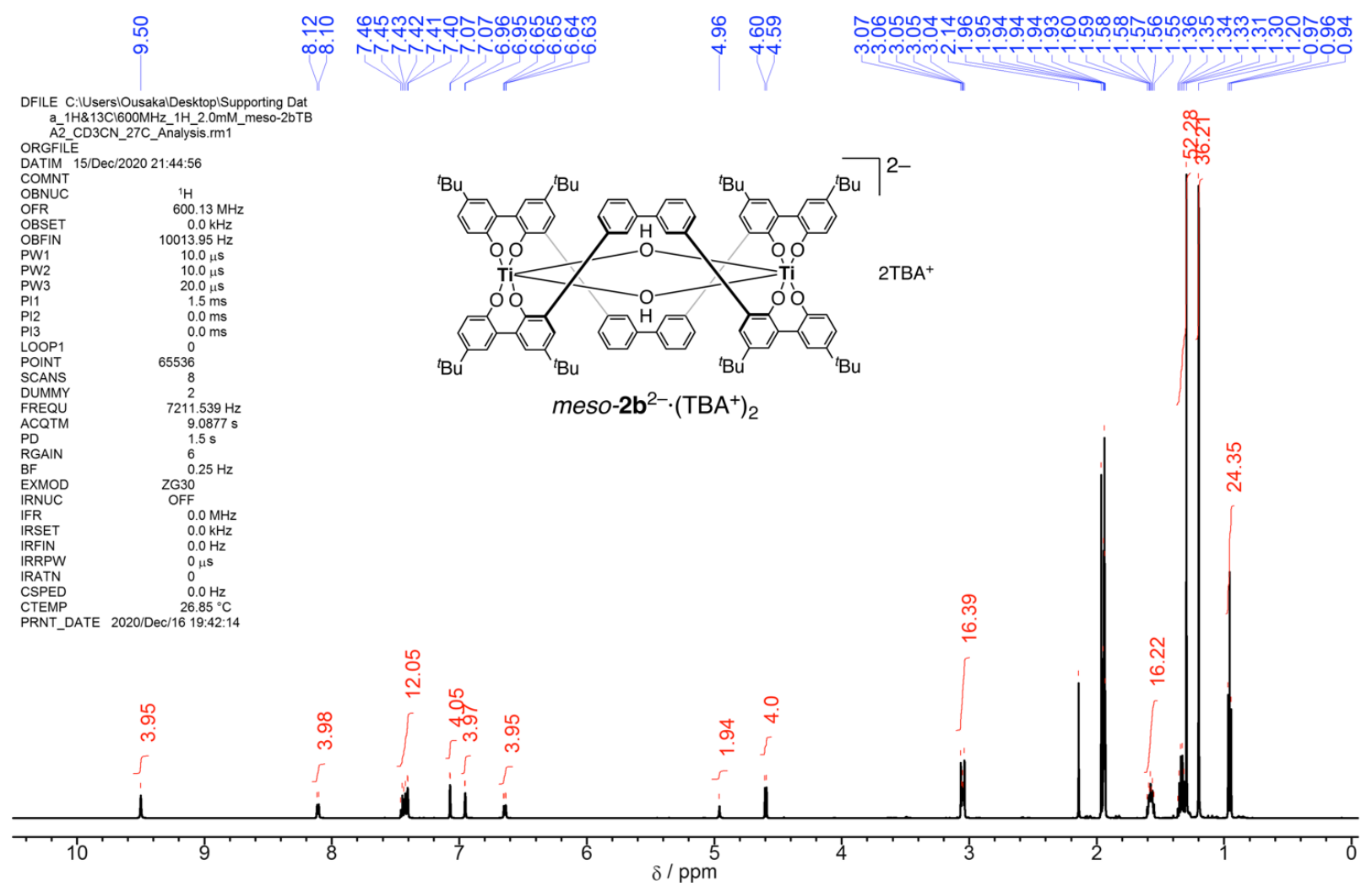

Figure S58. ${ }^{1} \mathrm{H}$ NMR spectrum of $m e s o-2 \mathbf{b}^{2-} \cdot\left(\mathrm{TBA}^{+}\right)_{2}$ in $\mathrm{CD}_{3} \mathrm{CN}$ at $27^{\circ} \mathrm{C}$.

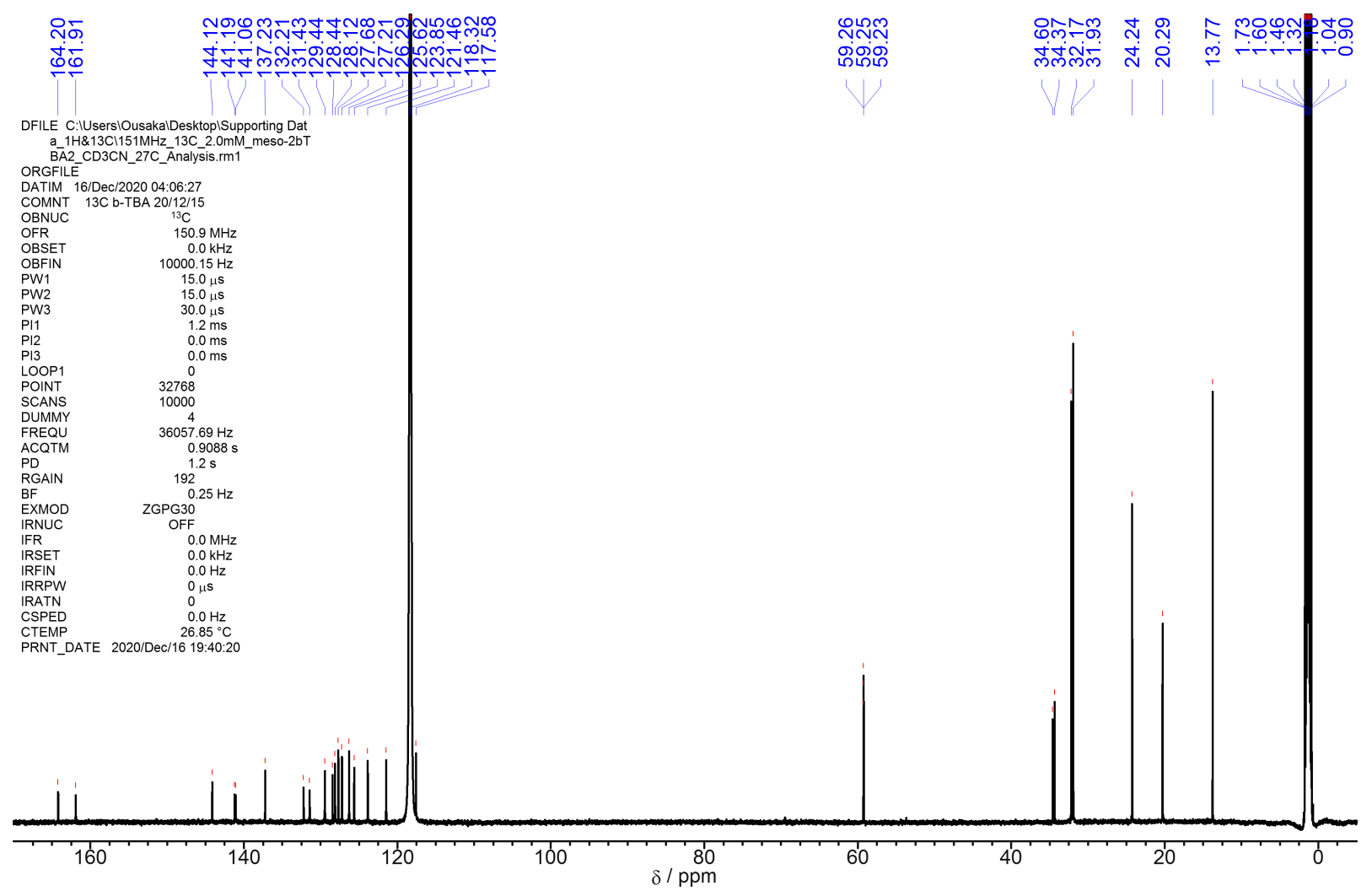

Figure S59. ${ }^{13} \mathrm{C}$ NMR spectrum of meso-2 $\mathbf{b}^{2-} \cdot\left(\mathrm{TBA}^{+}\right)_{2}$ in $\mathrm{CD}_{3} \mathrm{CN}$ at $27{ }^{\circ} \mathrm{C}$. 


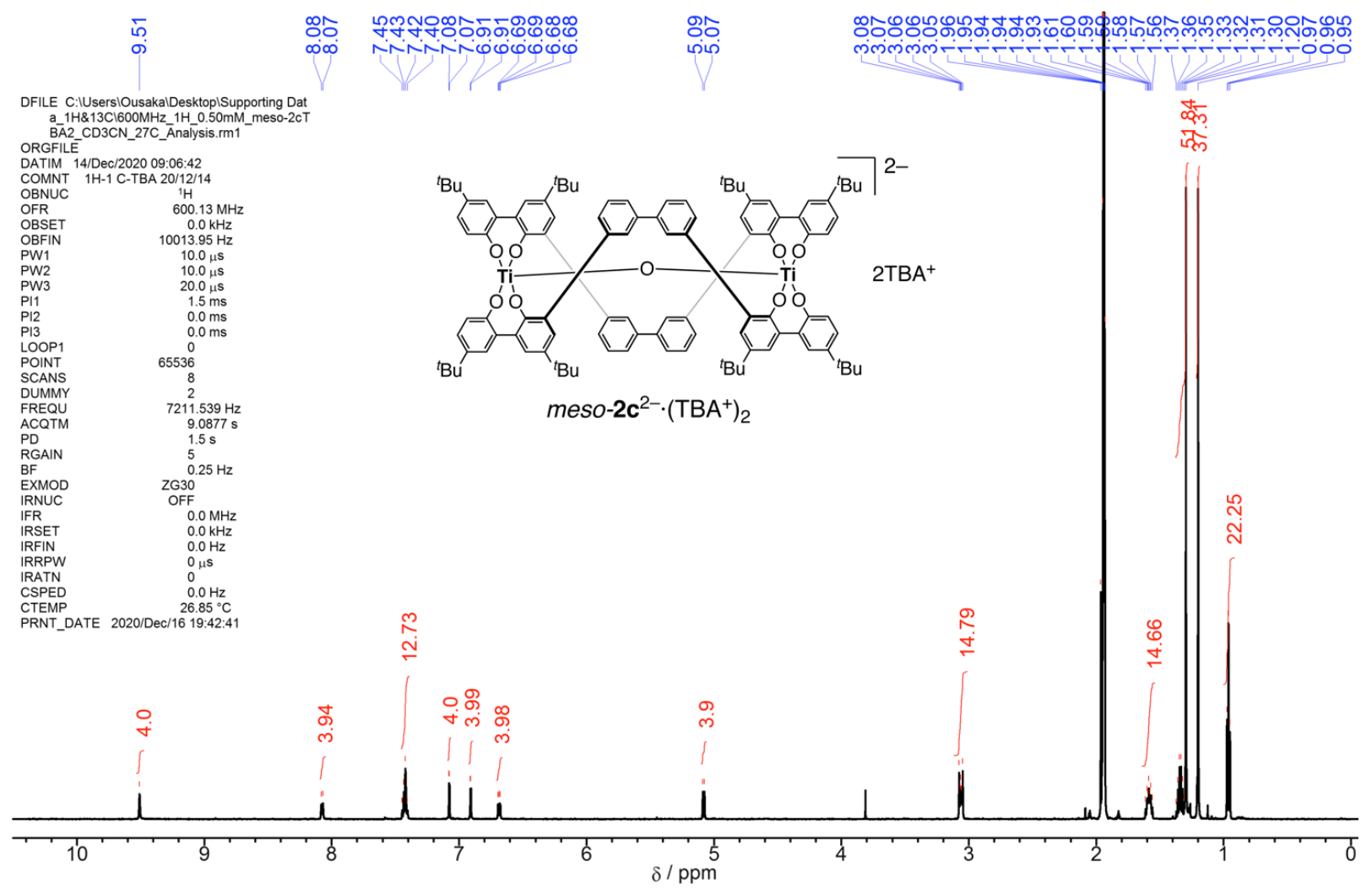

Figure S60. ${ }^{1} \mathrm{H}$ NMR spectrum of $m e s o-2 c^{2-} \cdot\left(\mathrm{TBA}^{+}\right)_{2}$ in $\mathrm{CD}_{3} \mathrm{CN}$ at $27{ }^{\circ} \mathrm{C}$.



Figure S61. ${ }^{13} \mathrm{C}$ NMR spectrum of meso-2c $\mathrm{c}^{2-} \cdot\left(\mathrm{TBA}^{+}\right)_{2}$ in $\mathrm{CD}_{3} \mathrm{CN}$ at $27{ }^{\circ} \mathrm{C}$. 